\title{
SURFACE-WATER AND SEDIMENT QUALITY IN THE \\ OLD LEAD BELT, SOUTHEASTERN MISSOURI--1988-89
}

By B.J. Smith and John G. Schumacher

U.S. GEOLOGICAL SURVEY

Water-Resources Investigations Report 93-4012

Prepared in cooperation with the

MISSOURI DEPARTMENT OF NATURAL RESOURCES, LAND RECLAMATION COMMISSION

Rolla, Missouri 


\section{U.S. DEPARTMENT OF THE INTERIOR}

BRUCE BABBITT, Secretary

U.S. GEOLOGICAL SURVEY

Dallas L. Peck, Director

For additional information write to:

District Chief

U.S. Geological Survey 1400 Independence Road

Mail Stop 200

Rolla, Missouri 65401
Copies of this report can be purchased from:

U.S. Geological Survey

Books and Open-File Reports Section

Federal Center

Box 25425

Denver, Colorado 80225 


\section{CONTENTS}

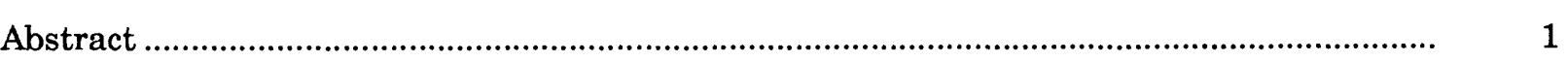

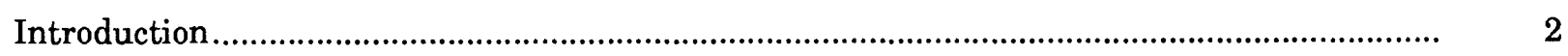

History of mining in the Old Lead Belt...................................................................

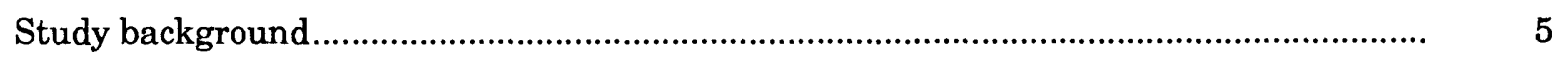

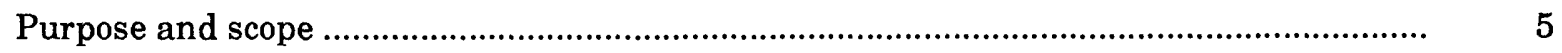

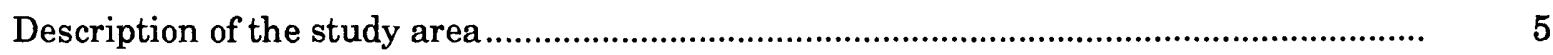

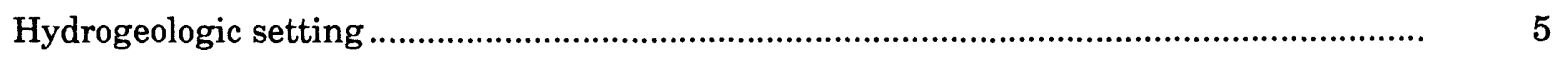

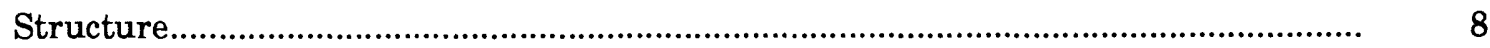

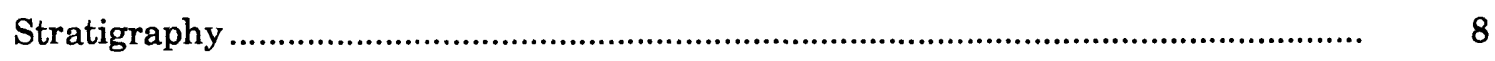

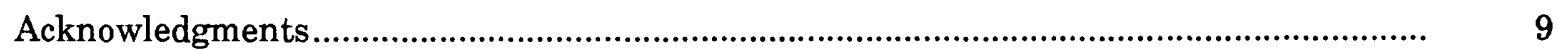

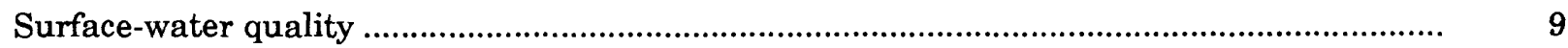

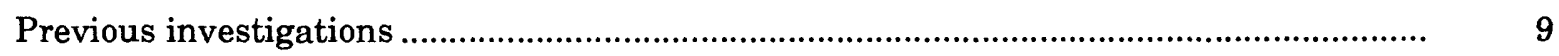

Location and description of sampling sites ................................................................. 11

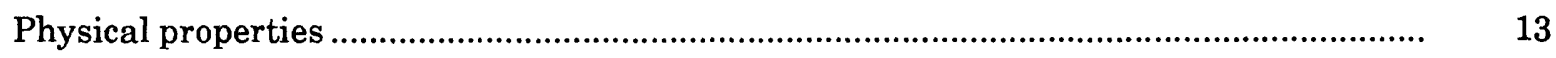

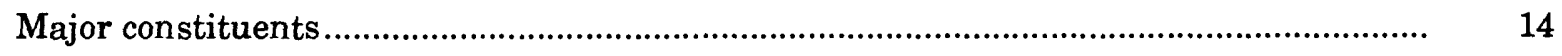

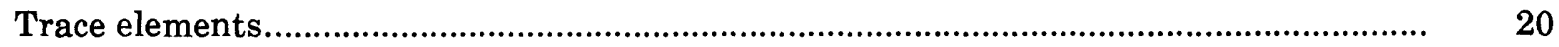

Relations between selected constituents.................................................................... 26

Water quality during periods of high flow ..................................................................... 26

Comparison of instantaneous constituent loads.........................................................

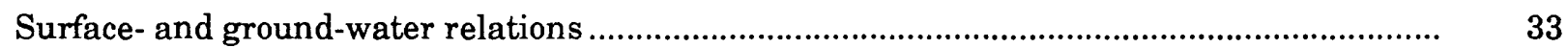

Seepage runs on the Big River and the Flat River .....................................................

Mass balance of selected constituents .......................................................................

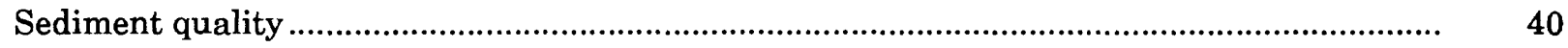

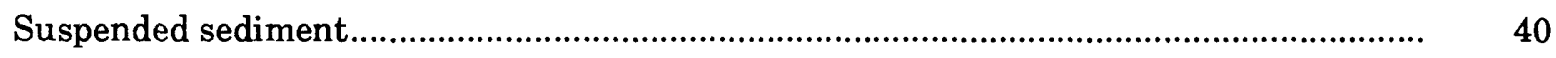

Particle-size distribution and chemical composition of suspended sediment during periods of high flow................................................................................. 41

Loads of selected trace elements ...............................................................................

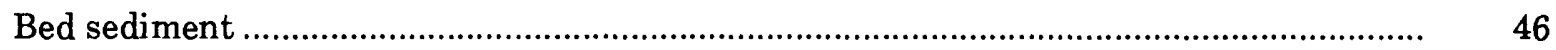

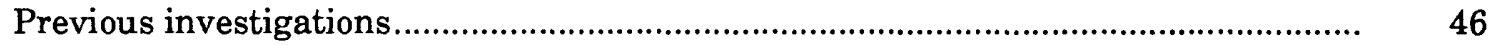

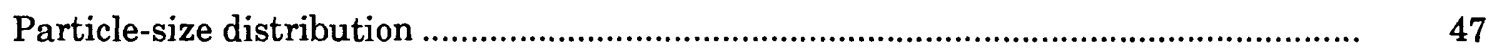

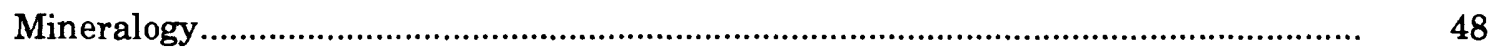

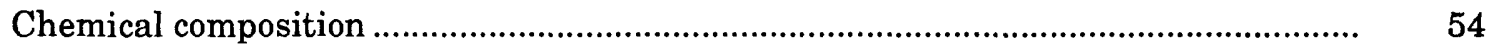

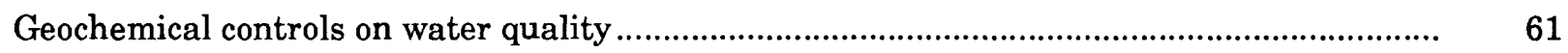

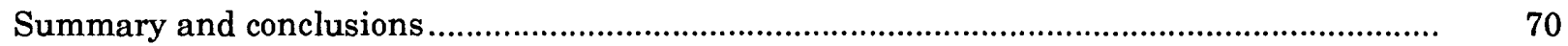

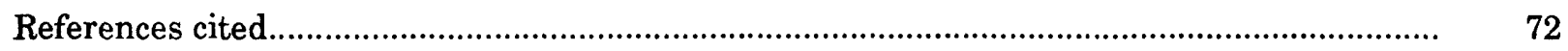




\section{ILLUSTRATIONS}

Page

Figures 1-3. Maps showing:

1. Location of the Old Lead Belt, southeastern Missouri, and generalized location of lead and zinc mining

2. Location of tailings piles ....................................................................

3. Principal structural features ............................................................ 6

4. Generalized stratigraphic section ..........................................................

5. Map showing water-quality and sediment sampling sites ........................... 10

6-13. Graphs showing:

6. Distribution of specific conductance and $\mathrm{pH}$ values at water-quality sampling sites....

7. Composition of water at water-quality sampling sites

8. Distribution of major constituent concentrations at water-quality sampling sites.

9. Distribution of selected trace-element concentrations at waterquality sampling sites....

10. Relation between dissolved zinc and cadmium at seepage sites

11. Relation between dissolved zinc and sulfate at water-quality sampling sites.

12. Relation between selected properties and constituents at sites 1 and 12

13. Distribution of instantaneous loads for selected constituents at water-quality sampling sites....

14-16. Maps showing:

14. Results of seepage run on the Big River, September 13, 1989

15. Results of seepage run on the Flat River, September 13, 1989

16. Results of seepage run on the Big River, November 6-8, 1989 . 


\section{ILLUSTRATIONS--Continued}

Figures 17-22. Graphs showing:

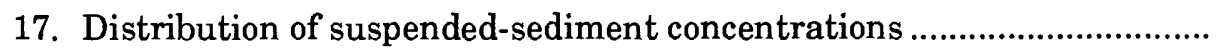

18. Daily mean discharge values from March 1988 through September 1989 at site 6

19. Suspended-sediment concentration as a function of daily mean discharge at site 6

20. Particle-size distribution of bed sediment.

21. Particle-size distribution of bed sediment at sites on the Big River

22. Distribution of quartz and carbonate minerals in the bulk samples .....

23. Scanning electron photomicrographs of bed sediment showing zinc carbonate coating dolomite particles from site 8

24. Scanning electron photomicrograph of bed sediment showing lead carbonate coating a carbonate particle from site 10

25-29. Graphs showing:

25. Mean concentrations of calcium and magnesium in fine and coarse fractions of bed sediment.

26. Mean concentrations of selected trace elements in fine and coarse fractions of bed sediment.

27. Relation between concentrations of zinc and cadmium in bed sediment in the Big River

28. Relation between concentrations of nickel and cobalt in bed sediment in the Big River

29. Relation between concentrations of zinc and lead in bed sediment in the Big River 


\section{TABLES}

Page

Table 1. Water-quality and sediment sampling sites

2. Summary statistics for selected physical properties and constituents at water-quality sampling sites

3. Missouri water-quality criteria for the protection of aquatic life and livestock and wildlife watering for the Big River and the Flat River

4. Physical properties and selected constituent concentrations for quarterly and high-flow samples

5. Mass-balance analysis of selected properties and constituents in the Big River

6. Element concentrations in suspended sediment in high-flow samples

7. Dissolved and suspended loads for selected trace elements in the Big River at site 6 at low flow

8. Total loads of barium, iron, lead, zinc, and suspended sediment transported by the Big River at site 6 for February 13-15, 1989, and for the period of record, March 1988 through September 1989

9. Mineralogy of the C-3 fraction (non-magnetic ore and non-ore minerals) from bed sediment.

10. Saturation indices of selected mineral phases at seepage sites as calculated by the geochemical program code WATEQ4F 


\section{CONVERSION FACTORS AND VERTICAL DATUM}

Multiply

acre

ton

mile

square mile

foot

inch

cubic foot per second
By

4,047

0.9072

1.609

259.0

0.3048

25.4

0.02832
To obtain

hectare

megagram

kilometer

hectare

meter

millimeter

cubic meter per second

Water temperature in degrees Celsius $\left({ }^{\circ} \mathrm{C}\right)$ can be converted to degrees Fahrenheit $\left({ }^{\circ} \mathrm{F}\right)$ by using the following equation:

$$
{ }^{\circ} \mathrm{F}=9 / 5\left({ }^{\circ} \mathrm{C}\right)+32
$$

Sea level: In this report, "sea level" refers to the National Geodetic Vertical Datum of 1929 (NGVD of 1929)--A geodetic datum derived from a general adjustment of the first-order level nets of the United States and Canada, formerly called Sea Level Datum of 1929. 


\title{
SURFACE-WATER AND SEDIMENT QUALITY IN THE OLD LEAD BELT, SOUTHEASTERN MISSOURI--1988-89
}

\author{
By \\ B. J. Smith and John G. Schumacher
}

\begin{abstract}
The quality of water and bed sediment in the Big River and the Flat River was evaluated as part of a study to determine the effects of mining on surface water and sediment. This study was conducted during 1988-89 in cooperation with the Missouri Department of Natural Resources, Land Reclamation Commission. The results of this study indicated that for the trace elements analyzed, the water quality of the Big River and the Flat River from March 1988 through September 1989 met the established water-quality criteria for the protection of aquatic life and livestock and wildlife watering as defined by the Missouri Department of Natural Resources, with the exception of one sample from the Flat River that exceeded the water-quality criteria for lead. The concentrations of most major constituents were not significantly different at seven sampling sites on these two rivers, with the exception of the most downstream site on the Flat River. However, relatively high sulfate concentrations commonly associated with mine drainage were detected in some reaches of the Big River. Trace-element concentrations at the river sites generally were smaller than the detection limit for the element, except for concentrations of barium, iron, manganese, strontium, and zinc.

Values of physical properties and concentrations of major constituents generally were large in seepage from mine tailings piles in the basins. Constituent concentrations in seepage from tailings piles generally were largest at the Elvins tailings pile, where values of specific conductance ranged from 823 to 1,540 microsiemens per centimeter at 25 degrees Celsius. In the dissolved phase, cobalt concentrations in seepage ranged from 310 to 610 micrograms per liter, lead concentrations ranged from 10 to 80 micrograms per liter, and zinc concentrations ranged from 3,500 to 18,000 micrograms per liter. The presence of zinc carbonate or the solubility of this compound seems to control the upper limit of zinc concentrations at various seepage sites.
\end{abstract}

Seepage runs on the Big River and the Flat River during high base-flow conditions indicated that discharge in both streams was relatively constant or increased downstream throughout the reach that was measured. Mass-balance calculations on selected constituent loads indicated that increased discharge in these streams was due to inflow from the abandoned mines.

The Big River downstream from Desloge transported about 41,000 tons of suspended sediment during the 19-month period of record. One single high-flow in February 1989 transported about 40 percent of the total suspended sediment for that period. At base-flow conditions, iron and lead were predominately transported in the suspended solid phase and barium and zinc were transported in the dissolved phase.

Bed-sediment mineralogy at sites in areas affected by mining differed from that at sites in areas unaffected by mining. Quartz was the predominant mineral in bed sediment at sites unaffected by mining activities. Bed sediment at stream sites affected by mining activities, however, contained larger quantities of carbonate minerals, including dolomite, ankerite, and calcite.

Mineralogic, chemical, and scanning electron microscope analyses of the bed sediment indicated that most trace elements were associated with the oxide phases. However, at the Elvins tailings pile, zinc primarily was associated with the carbonate phase. 
The trace-element concentrations in bed sediment generally were larger in sediment from the Big River downstream from the Leadwood tailings pile than in sediment from other sites. Trace-element concentrations generally decreased downstream from the Desloge tailings pile to Richwoods, about 45 river miles downstream from the mined area, but throughout this reach the trace-element concentrations of bed sediment exceeded concentrations in sediment upstream from the mining area.

Largest trace-element concentrations at seepage sites were detected at the Elvins tailings pile. Lead concentrations ranged from 2,800 to 38,000 micrograms per gram and zinc concentrations ranged from 9,000 to more than 100,000 micrograms per gram in sediment collected at these sites.

\section{INTRODUCTION}

Lead was mined for more than 100 years in an area known as the Old Lead Belt in southeastern Missouri (fig. 1). From 1907 to 1953 this area was the Nation's largest producer of lead. About 8.5 million tons of lead were produced (Wharton and others, 1975). Co-products of lead mining included zinc, copper, and silver. Zinc produced in the area during this period totaled about 34,000 tons (H.M. Wharton, Missouri Department of Natural Resources, Division of Geology and Land Survey, written commun., 1988).

\section{History of Mining in the Old Lead Belt}

Lead was discovered in southeastern Missouri in about 1700. The initial discovery was about $70 \mathrm{mi}$ (miles) west of St. Francois County (Kramer, 1976), but about 1720, lead was discovered south of St. Francois County in Madison County. Lead mines, which at that time consisted of shallow surface mines, soon spread northward into St. Francois County (Snyder and Gerdemann, 1968). In 1869, core drilling indicated large deposits of lead ore underlying Bonne Terre, Flat River, Leadwood, Desloge, and Elvins in St. Francois County, and lead mining in this area, which is now referred to as the Old Lead Belt, began to expand rapidly. During the late 1800's and the early 1900's, as many as 15 companies operated mines in this area. Mines were operated at Bonne Terre from 1864 to 1961, at Desloge from 1929 to 1958, and at Leadwood from 1915 to 1962 (U.S. Geological Survey and Missouri Division of Geology and Land Survey, 1967). The mines were gradually shut down during the late 1950's and early 1960's as the ore deposits were depleted and production from the Viburnum Trend or the New Lead Belt (about $35 \mathrm{mi}$ southwest of the Old Lead Belt), with its higher-grade ore, expanded. In October 1972, the last mining operation in the Old Lead Belt closed (Kramer, 1976).

Early mining in the Old Lead Belt consisted primarily of mining galena crystals from shallow pits. Most of the surface deposits were depleted by the mid-1860's. From 1800 to 1850 , a few mine shafts as much as $80 \mathrm{ft}$ (feet) deep were completed in the Cambrian dolostone. However, until 1869, shallow workings, either pit or trench, were the primary means of ore removal. After 1869 when ore deposits were discovered about $120 \mathrm{ft}$ beneath several of the present day towns in the area (Kramer, 1976), numerous shafts were excavated to remove the ore.

Processing of lead ore using either mechanical or chemical separators produced large volumes of waste materials referred to as mine tailings. During the early years of mining in the Old Lead Belt, coarse tailings were produced from mechanical separators that concentrated the ore. In later years, more efficient chemical separators that produced finer-grained tailings were used (Wixson and others, 1982). However, both methods produced large volumes of tailings that contained varying quantities of trace elements. About 250 million tons of tailings were produced in the Old Lead Belt (Kramer, 1976). The tailings were placed directly on the land surface (fig. 2); coarse tailings were placed in piles and the fine tailings were transported in a slurry to areas called slime ponds in dammed valleys. Some tailings piles (such as the Desloge tailings pile, fig. 2) are adjacent to streams and cover several hundred acres. An estimated 3,000 acres of tailings are in the Old Lead Belt (Missouri Department of Natural Resources, Division of Geology and Land Survey, written commun., 1983). 


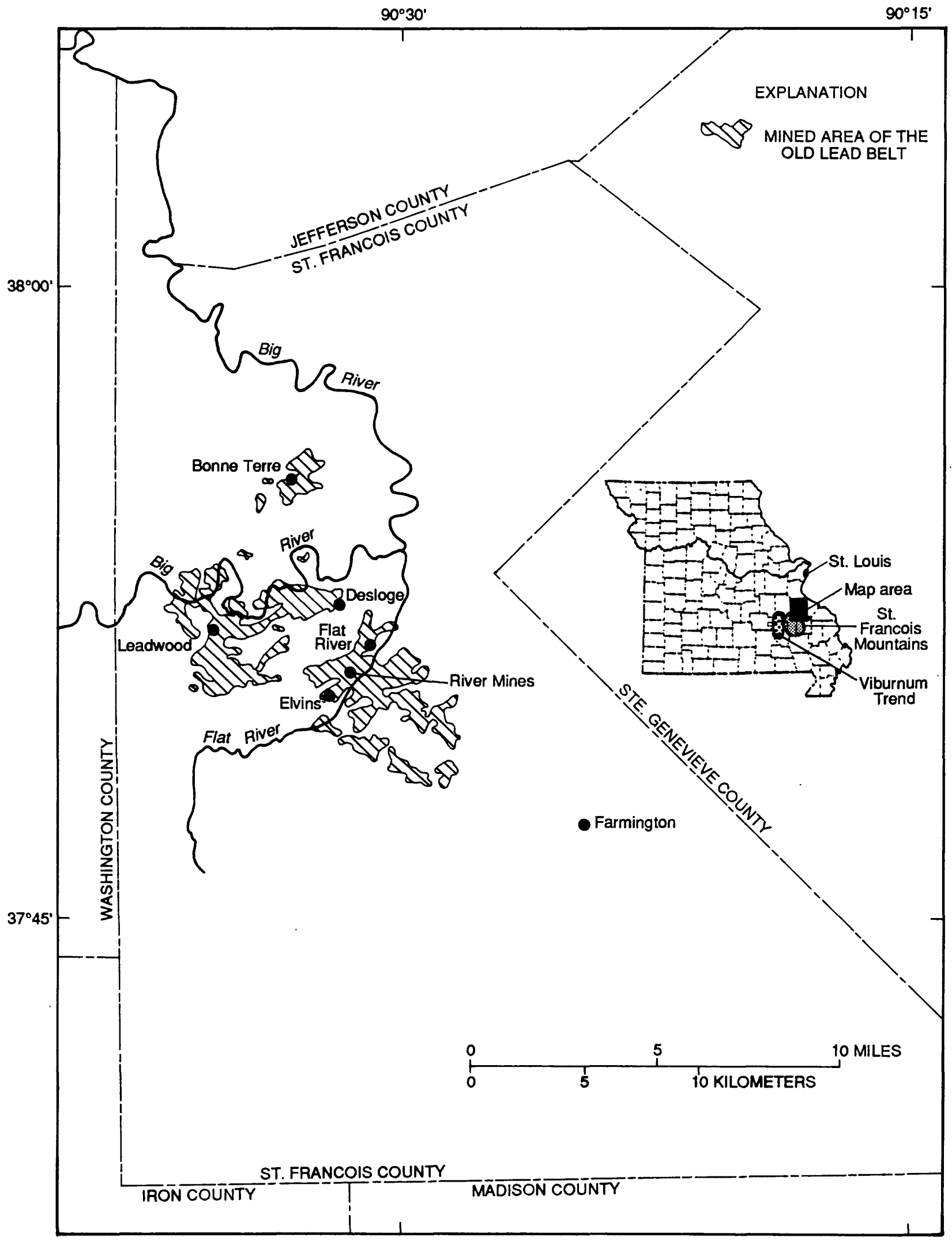

Figure 1.--Location of the Old Lead Belt, southeastern Missouri, and generalized location of lead and zinc mining (modified from Association of Missouri Geologists, 1969). 


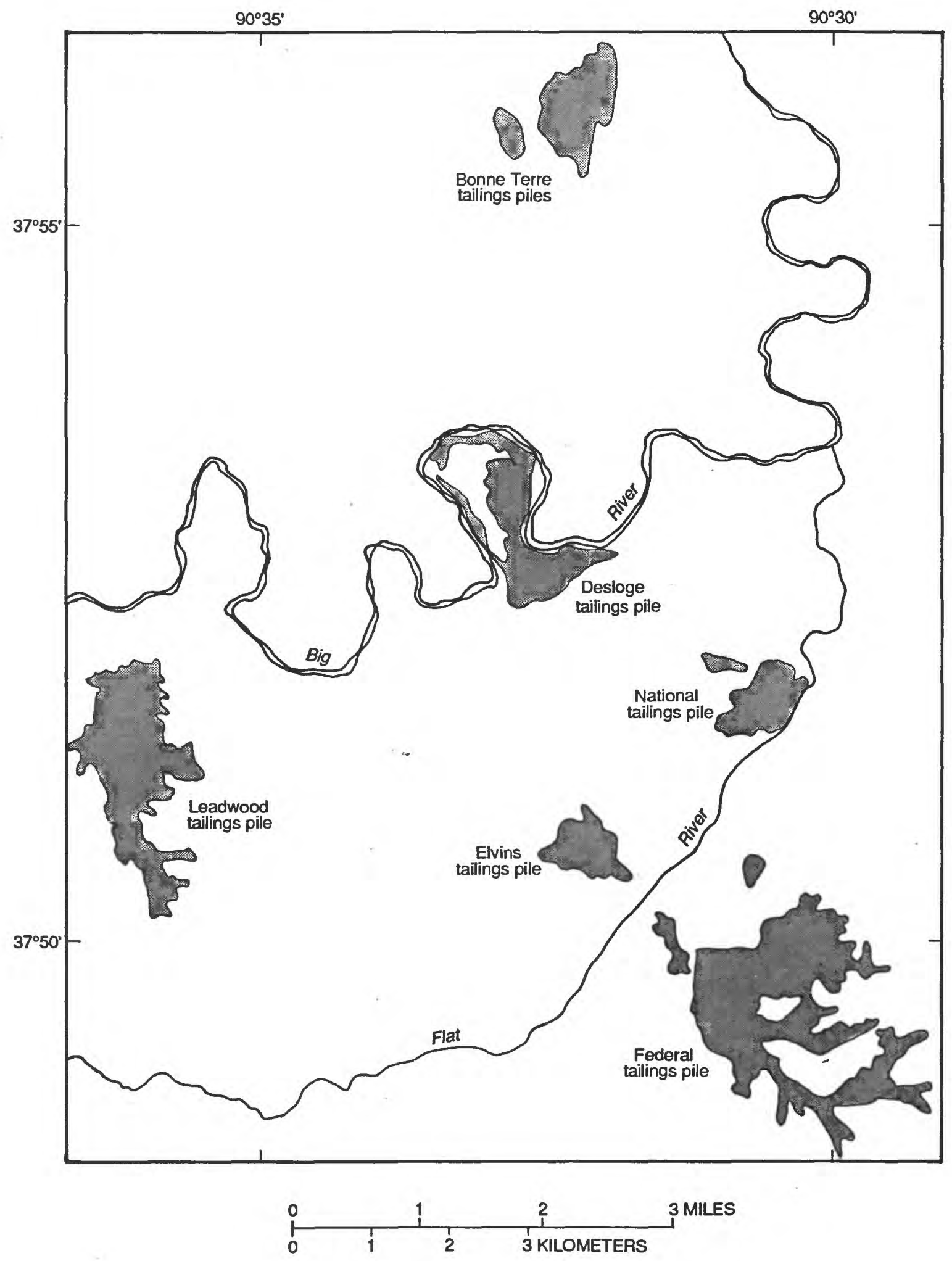

Figure 2.--Location of tailings piles. 


\section{Study Background}

A Statewide assessment of water quality in non-coal mining areas to determine those areas where mining of mineral resources other than coal had affected water resources was completed during 1988 (Smith, 1988). As a result of the Statewide assessment, a hydrologic investigation was begun in the Old Lead Belt, where a major concern is the effects of tailings piles on surface-water and sediment quality. The investigation was conducted by the U.S. Geological Survey, in cooperation with the Missouri Department of Natural Resources, Land Reclamation Commission. Data collection for the investigation began in 1988 and ended in 1989. The data collected as part of the investigation are presented in a report by Smith and Schumacher (1991).

\section{Purpose And Scope}

The purpose of this report is to present the results of the hydrologic investigation of the surface-water and sediment quality in the Old Lead Belt. The objectives of the investigation were to determine the surface-water quality at base flow and high flow, determine the physical and chemical processes that govern water quality, determine the trace-element concentration of various size fractions of suspended and bed sediment, and determine loads of dissolved and solid phases of selected trace elements. The report describes selected physical properties and chemical constituents and relations between selected constituents in surface water in the area; surface- and ground-water relations; selected constituent concentrations for base-flow and high-flow conditions; bed-sediment characteristics, including particle-size distribution, mineralogy, and chemical composition; and geochemical simulations used to aid in the interpretation of the water chemistry.

\section{Description of the Study Area}

The study area is in southeastern Missouri, about $70 \mathrm{mi}$ south of St. Louis (fig. 1) and encompasses most of St. Francois County, including the Old Lead Belt, and parts of Jefferson and Washington Counties. The area of primary interest is the area in and near the Old Lead Belt that occupies an area of about $110 \mathrm{mi}^{2}$ (square miles) in central St. Francois County. The study area is located within the Salem Plateau of the Ozark Plateaus physiographic province (Fenneman, 1938). The topography of the area is rugged with narrow, steep drainage divides and several hundred feet of relief. Land-surface altitudes range from about 700 to $1,000 \mathrm{ft}$ above sea level. Mean annual precipitation in the area is about 40 in. (inches), but thunderstorms and frontal systems can produce rainfall totals in excess of several inches. During 1988, precipitation was below normal and totaled only 33.5 in. at Farmington, about $10 \mathrm{mi}$ southeast of the Old Lead Belt (National Oceanic and Atmospheric Administration, 1988).

The principal stream in the area is the Big River, which flows eastward and northward through the Old Lead Belt and northwest through the northern part of the study area. The largest tributary to the Big River in the Old Lead Belt is the Flat River. The Big River is a perennial, gaining stream, whereas the Flat River is an intermittent stream that gains in some reaches (Missouri Department of Natural Resources, 1986) but probably loses water to the ground-water system in other reaches (Kramer, 1976).

\section{Hydrogeologic Setting}

A generalized description of the structure and stratigraphy of the study area follows. Structural features are shown in figure 3 and a generalized stratigraphic section is shown in figure 4. 


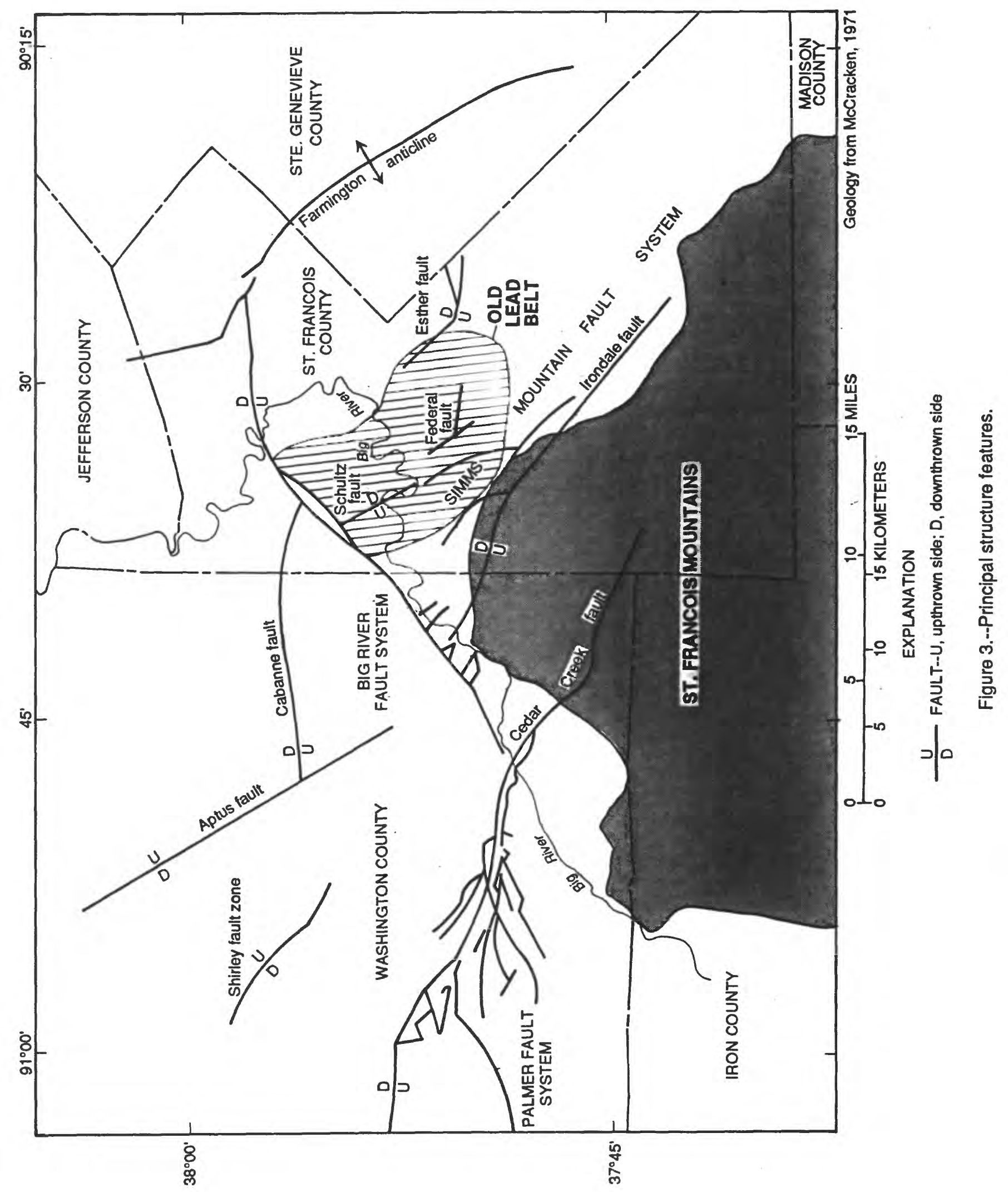




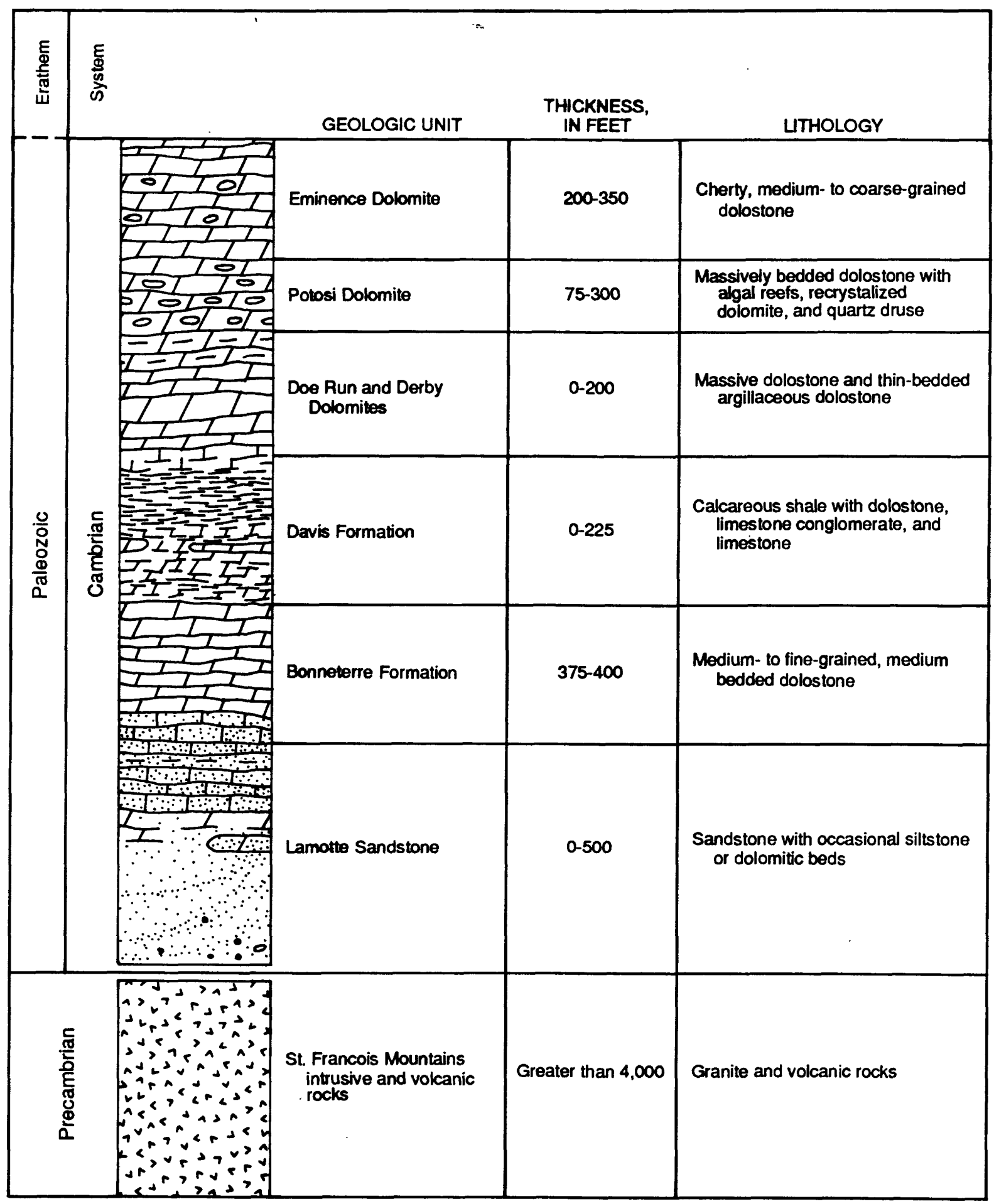

Figure 4.--Generalized stratigraphic section (modified from Imes and Smith, 1990). 


\section{Structure}

The main structural feature in the area is the Ozark uplift or Ozark dome, the core of which is composed of Precambrian granite and volcanic rocks exposed in the St. Francois Mountains, about $10 \mathrm{mi}$ south of the Old Lead Belt (fig. 3). The Old Lead Belt is in a triangular area bounded by the Simms Mountain Fault System on the southwest, the Big River Fault System on the northwest, and the Farmington anticline on the northeast. Many steeply dipping faults with displacements of $100 \mathrm{ft}$ or less have been mapped within the mineralized area (Snyder and Gerdemann, 1968).

\section{Stratigraphy}

Geologic formations of Cambrian and Precambrian age (fig. 4) are exposed in the area. A brief description of each formation follows (Koenig, 1961; U.S. Geological Survey and Missouri Division of Geology and Land Survey, 1967; Snyder and Gerdemann, 1968; McCracken, 1971):

1. Eminence Dolomite of Cambrian age is a medium to massively bedded, cherty, light gray, medium- to coarse-grained dolostone. The Eminence Dolomite has an approximate thickness of 200 to $250 \mathrm{ft}$, but locally can be as much as $350 \mathrm{ft}$ thick.

2. Potosi Dolomite of Cambrian age is a brown, massively bedded, siliceous dolostone consisting largely of algal reef and recrystallized oolitic dolomite. The silica is in the form of quartz druse. The thickness of the Potosi Dolomite averages $200 \mathrm{ft}$.

3. Doe Run and Derby Dolomites of Cambrian age is composed of two units. The upper unit is a massive oolitic dolostone or algal reef dolostone and the lower unit is a thin-bedded, argillaceous dolostone. Less than 10 percent of the Doe Run and Derby Dolomites is chert. Glauconite is present in the lower part. The thickness of the Doe Run and Derby Dolomites averages about $150 \mathrm{ft}$, but can range from 0 to $200 \mathrm{ft}$.

4. Davis Formation of Cambrian age is a thin-bedded, sandy, and calcareous shale with dolostone, limestone conglomerate, and limestone. The conglomerate consists of two types--"flat pebble" and "edgewise." The "flat pebble" type consists of rounded, disc-like pebbles of fine-grained limestone that are imbedded in a matrix of medium-grained limestone. In the "edgewise" conglomerate, the discs or lenses of fine-grained limestone are arranged with their longer axes perpendicular to or steeply inclined to the bedding planes. The thickness of the Davis Formation in the study area is about $170 \mathrm{ft}$.

5. Bonneterre Formation of Cambrian age is a medium- to fine-grained, medium-bedded dolostone in the study area. It is the host rock for the ore deposits in the Old Lead Belt, where eight principal units of the Bonneterre Formation have been recognized. Major lead production has been from the lower one-half of the formation, where depositional controls, including carbonate ridges, algal structures, and submarine breccia, have been responsible for ore concentration. The deposits occur on the flanks of buried or exposed topographic highs of Precambrian age near where the Lamotte Sandstone of Cambrian age pinches out against the Precambrian highs. The Bonneterre Formation typically is from 375 to $400 \mathrm{ft}$ thick.

6. Lamotte Sandstone of Cambrian age predominantly is a sandstone with occasional siltstone or dolomitic beds in the upper part. It is thickest (about $500 \mathrm{ft}$ ) in depressions between Precambrian knobs and pinches out against Precambrian knobs. Near the Precambrian contact, it grades into a basal arkosic conglomerate.

7. The Precambrian is composed of granite and volcanic rocks. Some Precambrian knobs can be exposed at land surface, whereas others are buried by overlying sedimentary rock. 


\section{Acknowledgments}

The authors thank the many people that contributed information or provided other forms of assistance during the course of this study. The authors extend their special thanks to Bryant Aubuchon, St. Francois County Landfill; John E. Carter and Harold Myers, the Doe Run Company; Ira Satterfield and James Brown, Missouri Department of Natural Resources, Division of Geology and Land Survey; Christopher J. Schmitt and Susan Finger, U.S. Fish and Wildlife Service; and Nord Gale, University of Missouri-Rolla. Support of this study by the U.S. Department of the Interior, Office of Surface Mining Reclamation and Enforcement, is acknowledged. However, the contents of this publication do not necessarily reflect the views and policies of the Office of Surface Mining Reclamation and Enforcement.

\section{SURFACE-WATER QUALITY}

Surface-water quality was determined for sites on the Big River and the Flat River and for sites associated with seepage from the tailings piles in the area. Physical properties, major constituent concentrations, and trace-element concentrations were determined for these sites.

The distribution of physical properties, major constituent concentrations, and trace-element concentrations are presented in this report using boxplots (Tukey, 1977). The box in these boxplots represents the middle 50 percent of data. The median value is plotted as a horizontal line within the box. The top of the box represents the 75th percentile and the bottom the 25th percentile. The box length represents the interquartile range. Vertical lines are drawn from the quartiles to two "adjacent" values. The upper value is defined at the largest data point less than or equal to the upper quartile plus 1.5 times the interquartile range. The lower adjacent value is the smallest data point greater than or equal to the lower quartile minus 1.5 times the interquartile range. Values more extreme in either direction are plotted individually. Values 1.5 to 3.0 times the interquartile range (outside values) are represented by an asterisk. Values larger than 3.0 times the interquartile range (far-out values) are represented by open circles.

\section{Previous Investigations}

During 1964, the Missouri Water Pollution Board published results of a water-quality survey of the Big River. The results of that survey indicated that mining had adversely affected the water quality of the Big River downstream from the Old Lead Belt. Although the reported trace-element concentrations did not exceed the current (1991) criteria for protection of aquatic life, tailings were present in the Big River about 40 river mi downstream from Leadwood (fig. 1).

During 1980 and 1981, Schmitt and Finger (1982) determined concentrations of dissolved lead and zinc for the Big River. Upstream from the Old Lead Belt at Irondale (fig. 5), considered to be a control site by the investigators, total and dissolved lead concentrations were $5 \mu \mathrm{g} / \mathrm{L}$ (micrograms per liter) and total and dissolved zinc concentrations were $10 \mu \mathrm{g} / \mathrm{L}$ in all three samples collected at low, medium, and high flows. In the Big River downstream from the Desloge tailings pile during low flow in July 1980 , the dissolved lead concentration was $20 \mu \mathrm{g} / \mathrm{L}$ and the dissolved zinc concentration was $310 \mu \mathrm{g} / \mathrm{L}$. During high flow in May 1981, the dissolved lead concentration was $12 \mu \mathrm{g} / \mathrm{L}$, and the dissolved zinc concentration was $100 \mu \mathrm{g} / \mathrm{L}$ (Schmitt and Finger, 1982).

Kramer (1976) documented increased concentrations of dissolved trace elements in water in the Flat River during a low-flow period in June and July 1975 as a result of seepage from the Elvins tailings pile. Upstream from the tailings pile, lead concentrations in water in the river were less than $50 \mu \mathrm{g} / \mathrm{L}$, zinc concentrations were $80 \mu \mathrm{g} / \mathrm{L}$ or less, and cadmium concentrations were $10 \mu \mathrm{g} / \mathrm{L}$ or less. Seepage from the Elvins tailings pile had lead concentrations that ranged from 100 to $150 \mu \mathrm{g} / \mathrm{L}$, zinc concentrations that ranged from 7,800 to $9,200 \mu \mathrm{g} / \mathrm{L}$, and cadmium concentrations that ranged from 30 to $40 \mu \mathrm{g} / \mathrm{L}$. After seepage from the tailings pile entered the Flat River, lead concentrations downstream 


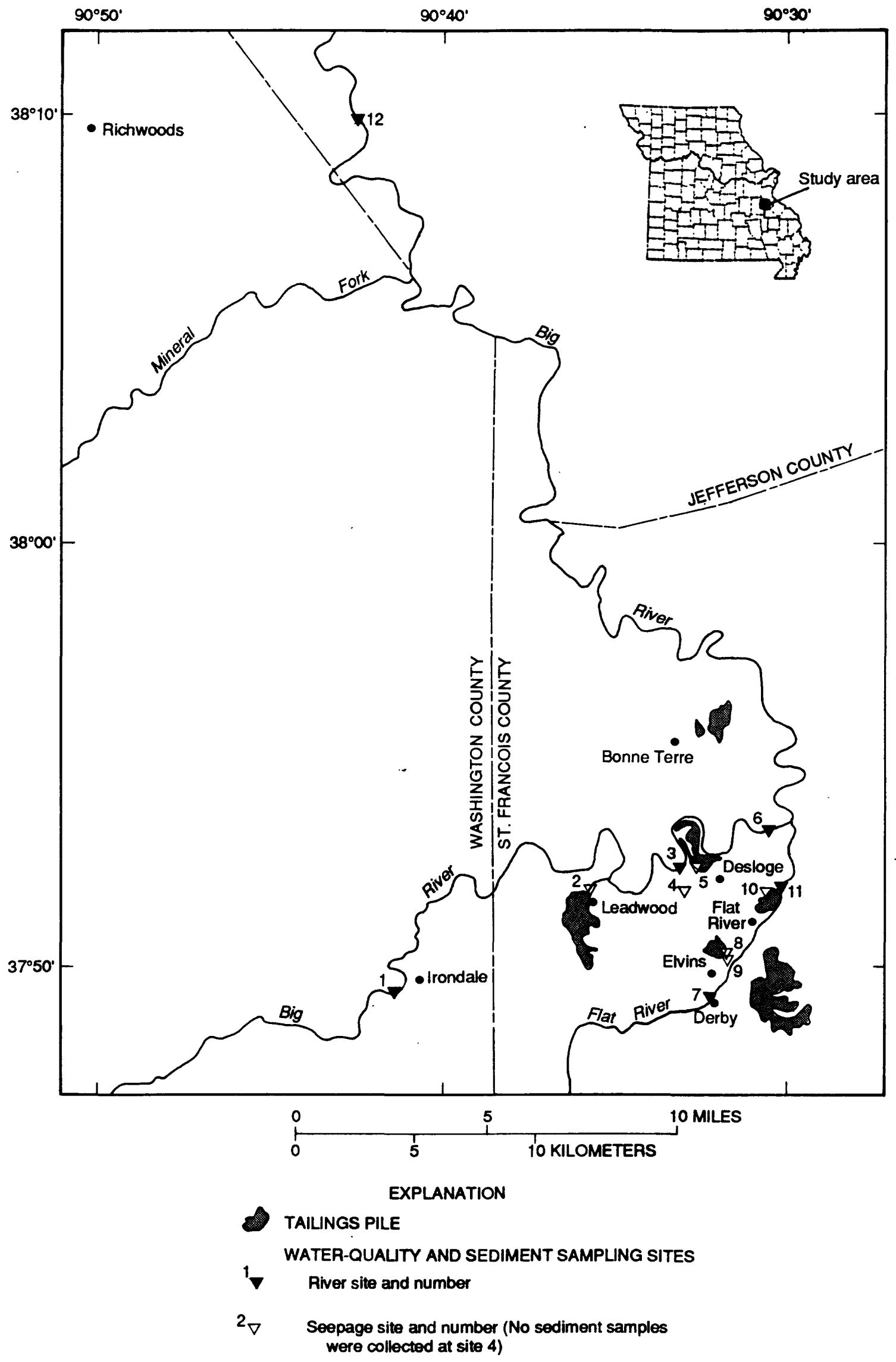

Figure 5.--Water-quality and sediment sampling sites. 
ranged from less than 50 to $150 \mu \mathrm{g} / \mathrm{L}$, zinc concentrations ranged from 3,200 to $4,800 \mu \mathrm{g} / \mathrm{L}$, and cadmium concentrations ranged from 10 to $40 \mu \mathrm{g} / \mathrm{L}$. In late July and August 1975, tailings pile seepage flowing through a series of impoundments before reaching the Flat River had lead concentrations that ranged from 10 to $230 \mu \mathrm{g} / \mathrm{L}$, zinc concentrations that ranged from 4,000 to $18,000 \mu \mathrm{g} / \mathrm{L}$, and cadmium concentrations that ranged from 20 to $40 \mu \mathrm{g} / \mathrm{L}$. All trace-element concentrations were dissolved.

\section{Location and Description of Sampling Sites}

Water-quality samples were collected quarterly at 12 sites in the study area (fig. 5 and table 1) from January 1988 to September 1989. Sample-collection methods, dates of collection, and results of chemical analyses are given in the report by Smith and Schumacher (1991). Discharge data at the time of sample collection and discharge hydrographs for gaged sites in the study area also are given in the report by Smith and Schumacher (1991).

Throughout this report, the sampling sites are referred to either as river sites or seepage sites, indicating the source of the water. River sites on the Big River are sites 1,3,6, and 12. River sites on the Flat River are sites 7 and 11. The seepage sites are those directly associated with the tailings piles--sites 2, 5, 8, 9, and 10 . Site 4 is a flowing exploration borehole and is considered to be representative of water from the abandoned mines.

Site 1 is on the Big River at Irondale at U.S. Geological Survey gaging station 07017200 that has been in operation since 1965. This location is considered to be indicative of background conditions. Even though some mining has been done in the area (Harold Myers, Doe Run Company, oral commun., 1989), no active mining has occurred since 1921 (Schmitt and Finger, 1982). Numerous diggings that yielded "considerable quantities" of lead and zinc were reported to have existed in the vicinity of Irondale in the 1800's, but by 1894 there had been little or no mining in this area for a number of years (Winslow, 1894). The drainage basin of the Big River at this site is about $175 \mathrm{mi}^{2}$. Average flow for the period of record (1965 to 1989) was $184 \mathrm{ft}^{3} / \mathrm{s}$ (cubic feet per second; Waite and others, 1990) and median instantaneous discharge measured during the collection of quarterly samples was $85 \mathrm{ft}^{3} / \mathrm{s}$. The river has a gravel bottom at this site.

Site 2 is on Eaton Creek, which is a small, steep gradient tributary to the Big River. Most of the drainage basin for Eaton Creek is covered with tailings from the Leadwood tailings pile, which covers about 560 acres (Missouri Division of Geology and Land Survey, written commun., 1983). The sampling site is directly upstream from a road culvert about 100 yards upstream from State Highway 8. Median instantaneous discharge measured during the collection of quarterly samples was about 0.3 $\mathrm{ft}^{3} / \mathrm{s}$. The bottom of the stream at this site consists of consolidated rock of the Bonneterre Dolomite.

Site 3 is on the Big River at what is locally known as the "Bonehole." This site is upstream from the Desloge tailings pile, which covers about 400 acres (Missouri Division of Geology and Land Survey, written commun., 1983). Water samples were collected at or below an abandoned low-water crossing that has a fall of about $3 \mathrm{ft}$. The median instantaneous discharge measured during the collection of quarterly samples was $134 \mathrm{ft}^{3} / \mathrm{s}$. The stream bed consists of gravel and tailings.

Site 4 is at a flowing abandoned exploration borehole. Discharge from the borehole represents water from the filled, abandoned mines. This site is on the right bank of the Big River near site 3 . Median instantaneous discharge was less than $0.25 \mathrm{ft}^{3} / \mathrm{s}$ during the collection of quarterly samples.

Site 5 is in a seepage channel about $500 \mathrm{ft}$ downstream from the northwest opening of a tunnel underneath the southwestern part of the Desloge tailings pile. The St. Francois County landfill is on the central part of the tailings pile. Flow from the tunnel consists of seepage from the tailings pile through the tunnel walls and runoff from the tailings pile and surrounding area. Median instantaneous discharge at site 5 measured during the collection of quarterly samples was less than $0.1 \mathrm{ft}^{3} / \mathrm{s}$. The bottom of the seepage channel consists of tailings and boulder-sized rocks. 


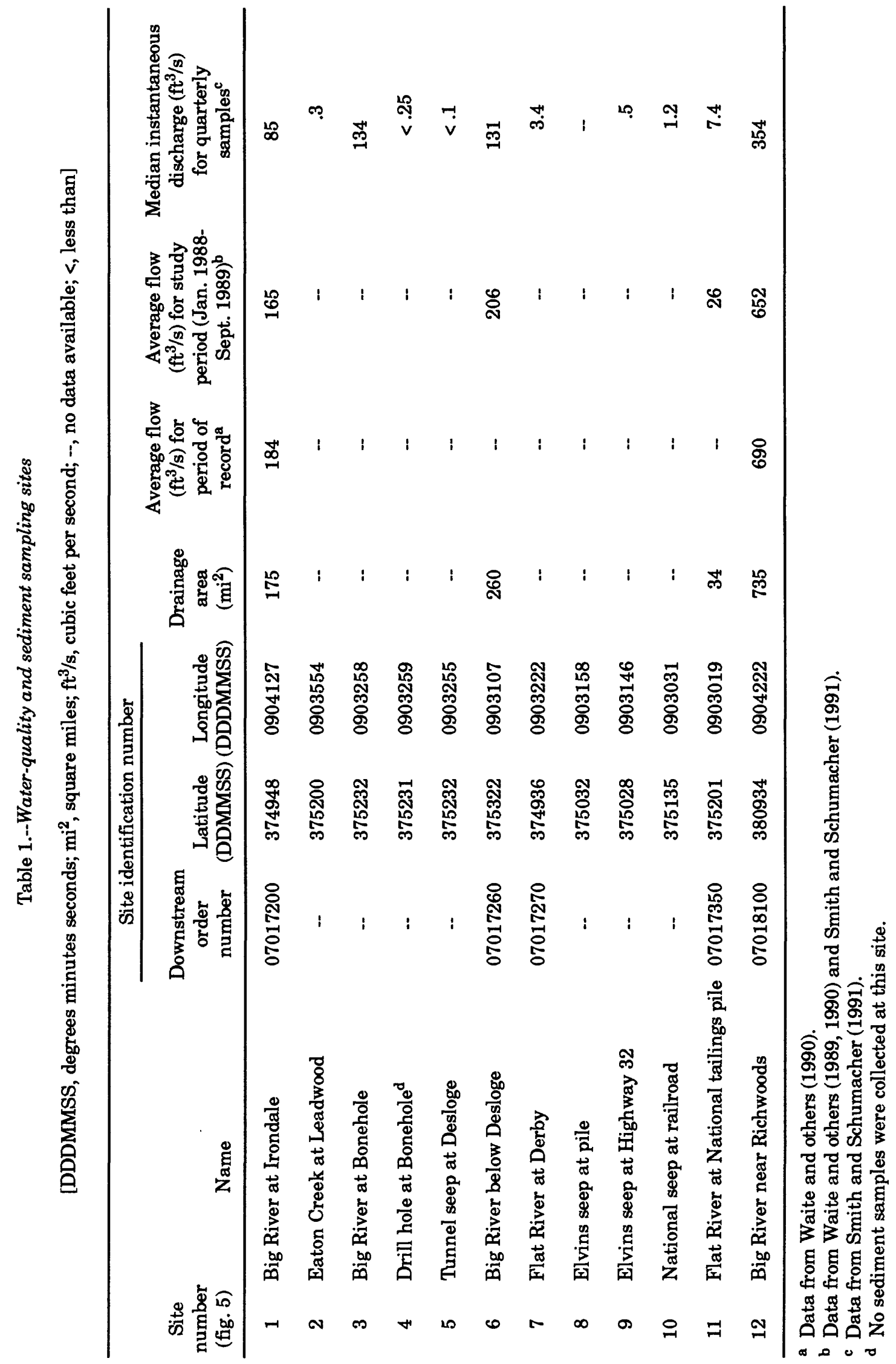


Site 6 is at gaging station 07017260 that was installed in January 1988 on the Big River downstream from the Desloge tailings pile. This site also is downstream from a quarry that produces crushed rock and dolomitic quicklime. The drainage basin for this site is $260 \mathrm{mi}^{2}$. Median instantaneous discharge measured at site 6 during the collection of quarterly samples was $131 \mathrm{ft}^{3} / \mathrm{s}$. The stream bottom was unstable because of the presence of large quantities of tailings and shifting of the river channel was noted even after moderate increases in flow.

Site 7 is on the Flat River at Derby. This site was considered to represent background conditions in the Flat River. Median instantaneous discharge measured at this site during the collection of quarterly samples was less than $4 \mathrm{ft}^{3} / \mathrm{s}$. The bottom of the river channel is in the Davis Formation and consists of shale and dolostone.

Sites 8 and 9 are at the Elvins tailings pile, which covers about 150 acres (Missouri Division of Geology and Land Survey, written commun., 1983). The Elvins pile may be central to the part of the Old Lead Belt where zinc mineralization was locally abundant (Snyder and Gerdemann, 1968). Site 8 was at the base of the pile, and site 9 was immediately downstream from a box culvert on a seepage channel about $500 \mathrm{ft}$ downstream from the pile. Runoff or seepage from the tailings pile is diverted through a series of settling ponds before the water enters the seepage channel above site 9 . Seepage in the channel flows into the Flat River. Median instantaneous discharge measured just downstream from the culvert at site 9 during the collection of quarterly samples was about $0.5 \mathrm{ft}^{3} / \mathrm{s}$. The bottom of the channel consists of mine tailings.

Site 10 is in a seepage channel in the slime pond area of the National tailings pile, which covers about 175 acres (Missouri Division of Geology and Land Survey, written commun., 1983). The site is near an abandoned railroad through the slime pond area. In addition to runoff and seepage from the tailings pile, flow in the seepage channel included effluent from a glass factory that is adjacent to the tailings pile. The effluent consisted of ground water from abandoned mines that had been used for cooling purposes in the factory. The median instantaneous discharge measured during the collection of quarterly samples in the seepage channel was $1.2 \mathrm{ft}^{3} / \mathrm{s}$.

Site 11 is at gaging station 07017350 installed in January 1988 on the Flat River downstream from the National tailings pile. The median instantaneous discharge measured during the collection of quarterly samples at this site was $7.4 \mathrm{ft}^{3} / \mathrm{s}$. Material in the stream bed consists primarily of tailings and some large cobbles. Immediately downstream from the gaging station, the stream bed was composed entirely of tailings. The channel was unstable at this location because the presence of large quantities of tailings and shifting of the channel was noted even after moderate increases in flow.

Site 12, which is the most downstream site on the Big River, is at U.S. Geological Survey gaging station 07018100 that was established in 1942. The drainage basin for the Big River at this site is $735 \mathrm{mi}^{2}$. Average flow for the period 1942 through 1989 was $690 \mathrm{ft}^{3} / \mathrm{s}$ (Waite and others, 1990). The median instantaneous discharge measured during the collection of quarterly samples was 354 $\mathrm{ft}^{3} / \mathrm{s}$. The streambed was gravel covered. Site 12 is about 45 river mi downstream from the Desloge tailings pile and less than 10 river mi downstream from Mineral Fork (fig. 5), which drains the Washington County barite district. Barite has been mined in this area since about 1850 . The barite is mined from residual deposits and is separated from the residual clays in washer plants. Wastes from the washer plants are diverted to tailings ponds along tributaries to Mineral Fork.

\section{Physical Properties}

Specific conductance values generally were smallest at the river sites, with median values generally less than $500 \mu \mathrm{S} / \mathrm{cm}$ [microsiemens per centimeter at $25^{\circ} \mathrm{C}$ (degrees Celsius)]. Median specific conductance values in the Big River increased from $300 \mu \mathrm{S} / \mathrm{cm}$ at site 1 to $420 \mu \mathrm{S} / \mathrm{cm}$ at site 3 and $504 \mu \mathrm{S} / \mathrm{cm}$ at site 6 , then decreased to $444 \mu \mathrm{S} / \mathrm{cm}$ at site 12 . The median specific conductance value at site 12 was similar to that at site 3 but larger than that at site 1 . The specific conductance values 
at site 12 may reflect dilution by additional sources of surface and ground water in the Big River rather than a decrease of mining-related constituents. Significant differences in specific conductance of river water were detected between sites 1 and 3 and sites 1 and 6 on the Big River, but no significant difference was detected between sites 3 and 6 .

Significant increases in specific conductance of water in the Flat River also were detected between the upstream site (site 7) and the downstream site (site 11). The median specific conductance increased from $347 \mu \mathrm{S} / \mathrm{cm}$ at the upstream site to $732 \mu \mathrm{S} / \mathrm{cm}$ at the downstream site (fig. 6). Much of this increase can be attributed to inflow from the Elvins and National tailings piles and ground water discharging from the abandoned mines between the upstream and downstream sites. At base-flow conditions, these sources can account for a substantial part of the flow at the downstream site. For example, in May 1988, the flow increased from $3.4 \mathrm{ft}^{3} / \mathrm{s}$ at site 7 to $6.3 \mathrm{ft}^{3} / \mathrm{s}$ at site 11 . Inflow from the Elvins and National tailings piles was 0.2 and $1.3 \mathrm{ft}^{3} / \mathrm{s}$. Thus, inflow of seepage from these two piles accounted for about 24 percent of the flow at the downstream site--and more than 50 percent of the increase in flow. An additional 22 percent of the flow at site 11 that could not be accounted for by surface-water inflow probably represented ground-water discharge from abandoned mines.

The largest specific conductance values measured during this study were at seepage sites. At sites 8 and 9 at the Elvins tailings pile, specific conductance values ranged from 823 to $1,540 \mu \mathrm{S} / \mathrm{cm}$. At site 10, the median specific conductance was $955 \mu \mathrm{S} / \mathrm{cm}$, which is similar to the median value of 948 $\mu \mathrm{S} / \mathrm{cm}$ in water from the abandoned drill hole (site 4). Most of the flow at both of these sites is ground water from the abandoned mines.

Because of the abundance of carbonate minerals in the tailings and bedrock in the study area, $\mathrm{pH}$ values at all sites were near neutral to slightly alkaline (fig. 6). The $\mathrm{pH}$ values at all river sites were similar; however, among the sites on the Big River there was a tendency for $\mathrm{pH}$ values to increase downstream (median $\mathrm{pH}$ at site 1 was 7.8 and median $\mathrm{pH}$ at site 12 was 8.2). With the exception of the drill hole (site 4, median pH of 7.2) and the seep at the base of the Elvins tailings pile (site 8, median $\mathrm{pH}$ of 6.7), the $\mathrm{pH}$ values for seepage sites were similar to the values for the river sites. The small $\mathrm{pH}$ values at site 8 were probably related to the oxidation of ferrous iron to ferric iron because orange-red iron oxide staining was observed at this seep. Significant increases in $\mathrm{pH}$ values were detected at site 9 a short distance downstream from site 8 and also at site 10 downstream from site 9 , probably from the dissolution of carbonate minerals. The $\mathrm{pH}$ values of the quarterly samples collected in September 1989 were consistently lower than previous measurements at each site, indicating possible equipment malfunction. A statistical summary of water-quality data collected from all sampling sites is presented in table 2 (at the back of this report).

\section{Maior Constituents}

The major-constituent composition of water samples from the river and seepage sites are plotted on the trilinear diagrams in figure 7. The water type for the river sites is generally a calcium magnesium bicarbonate. The water type for the seepage sites is a calcium magnesium sulfate bicarbonate to calcium magnesium bicarbonate.

Generally, the distributions of calcium, magnesium, potassium, and sulfate concentrations were similar to the distribution of specific conductance values (fig. 8). Seepage sites generally had larger concentrations of major constituents than the river sites. Although concentrations of most major constituents at river sites tended to be larger downstream from tailings piles, significant increases were detected in the concentrations of calcium (between sites 1 and 12 on the Big River and sites 7 and 11 on the Flat River), chloride (between sites 1 and 12 on the Big River), and sulfate (between sites 1 and 3 and sites 1 and 12 on the Big River and sites 7 and 11 on the Flat River). The increases in chloride concentrations probably are related to anthropogenic sources other than mining activities, as will be discussed. 

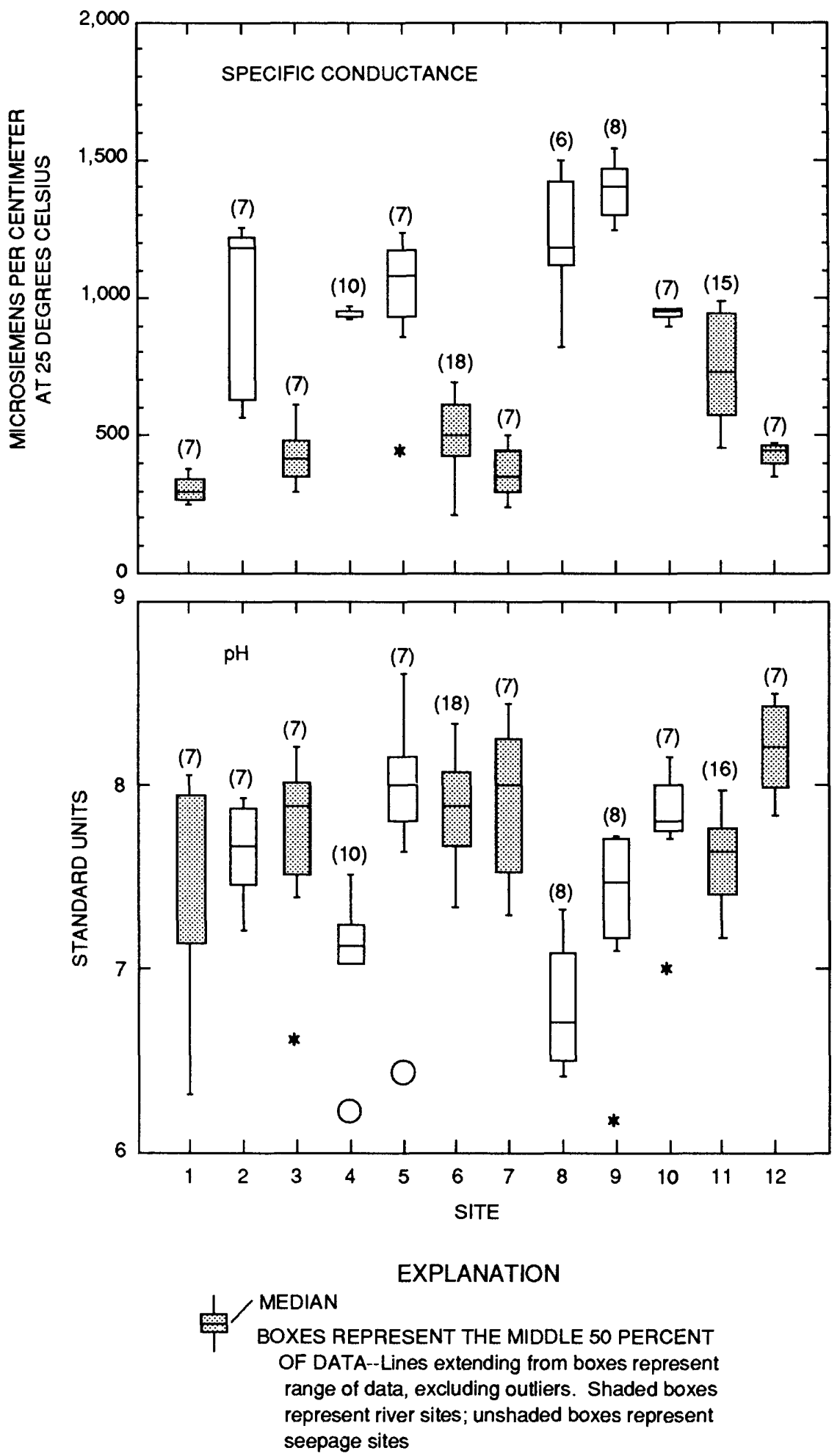

* VAlues one and one-half to three times THE INTERQUARTILE RANGE FROM THE TOP OR BOTTOM OF THE BOX

VALUES MORE THAN THREE TIMES THE INTERQUARTILE RANGE FROM THE TOP OR BOTTOM OF THE BOX

(7) NUMBER IN PARENTHESES INDICATES THE NUMBER OF SAMPLES

Figure 6.--Distribution of specific conductance and pH values at water-quality sampling sites. 


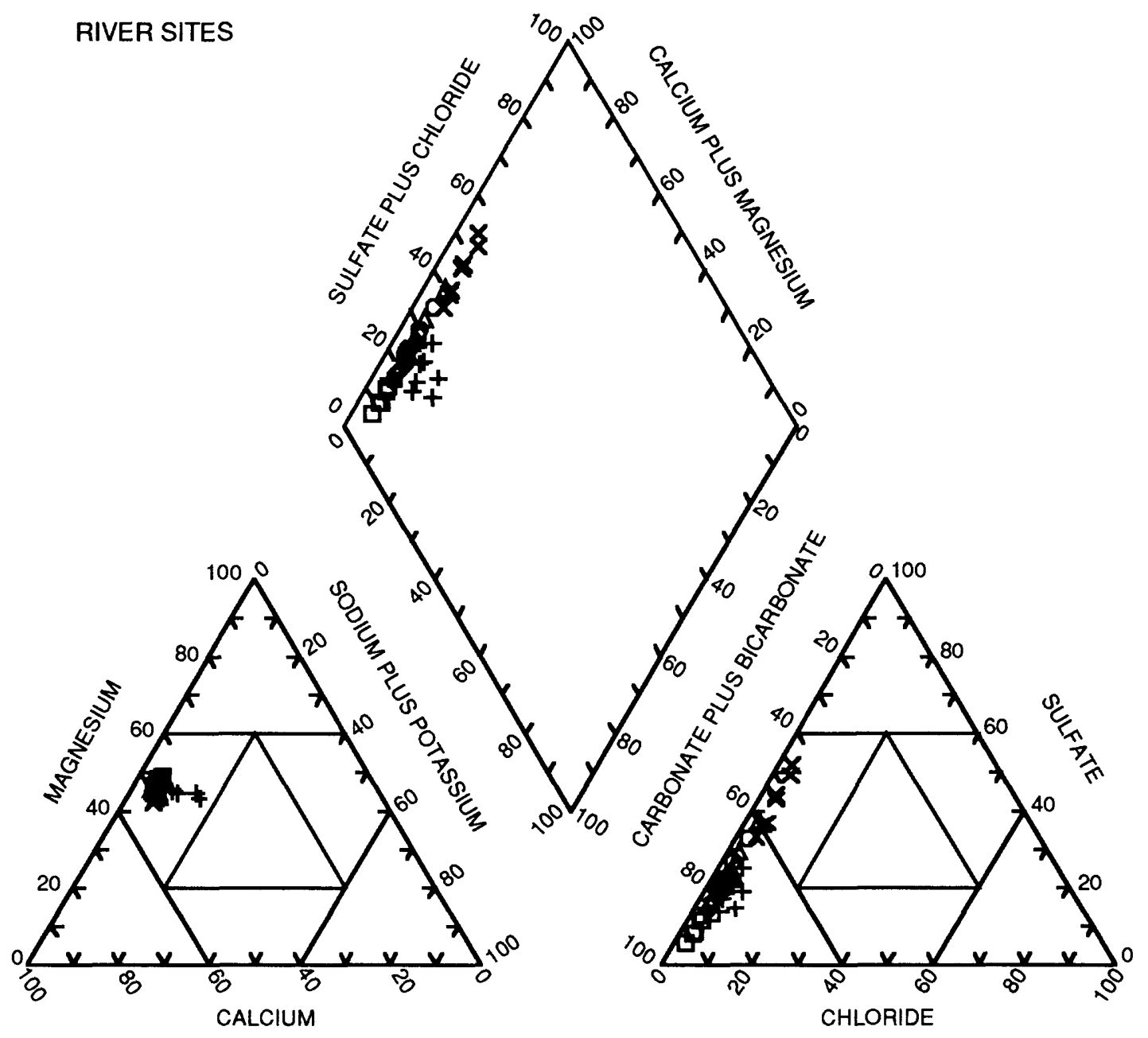

PERCENTAGE OF TOTAL MILLIEQUIVALENTS PER LITER

\section{EXPLANATION}

RIVER SITES

D Big River at Irondale (site 1)

- Big River at Bonehole (site 3)

$\Delta$ Big River below Desloge (site 6)

+ Flat River at Derby (site 7)

X Flat River at National tailings pile (site 11)

$\checkmark$ Big River near Richwoods (site 12)

Figure 7.--Composition of water at water-quality sampling sites. 


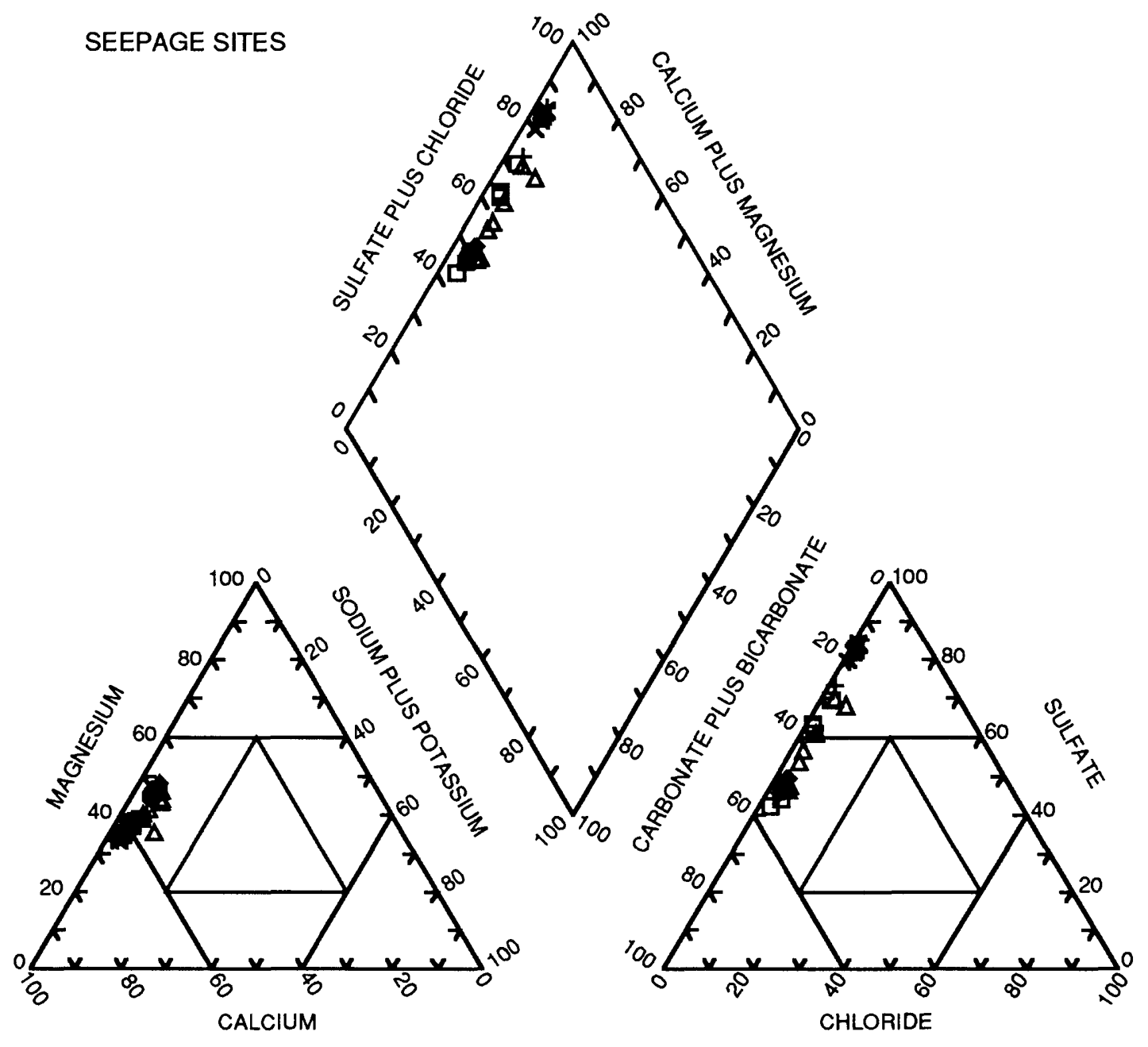

PERCENTAGE OF TOTAL MILLIEQUIVALENTS PER LITER

EXPLANATION

SEEPAGE SITES

- Eaton Creek at Leadwood (site 2)

- Drillhole at Bonehole (site 4)

$\Delta$ Tunnel seep at Desloge (site 5)

+ Elvins seep at pile (site 8)

$X$ Elvins seep at Highway 32 (site 9 )

- National seep at railroad (site 10)

Figure 7.--Composition of water at water-quality sampling sites--Continued. 

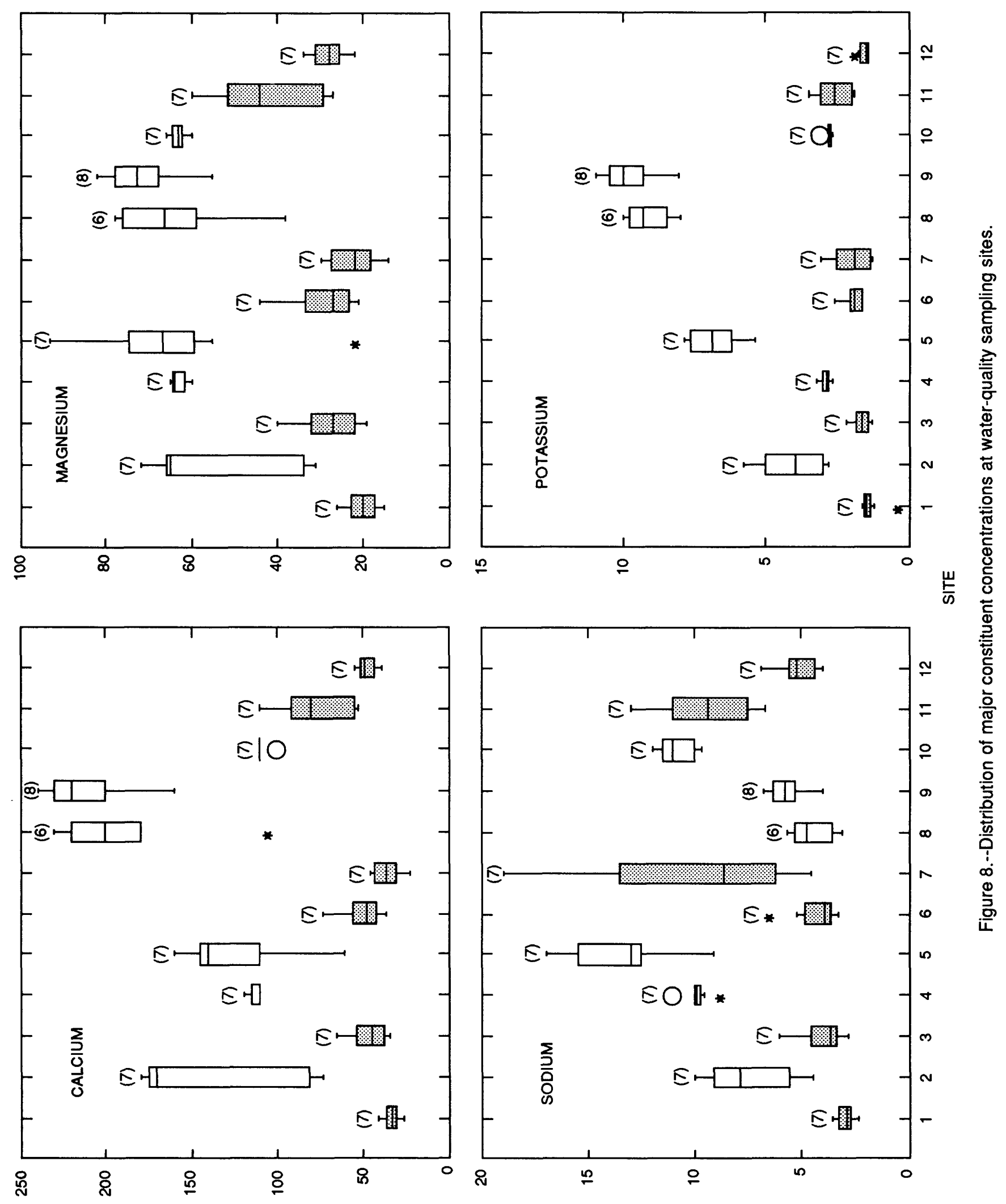

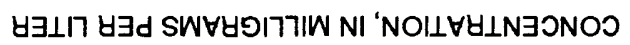



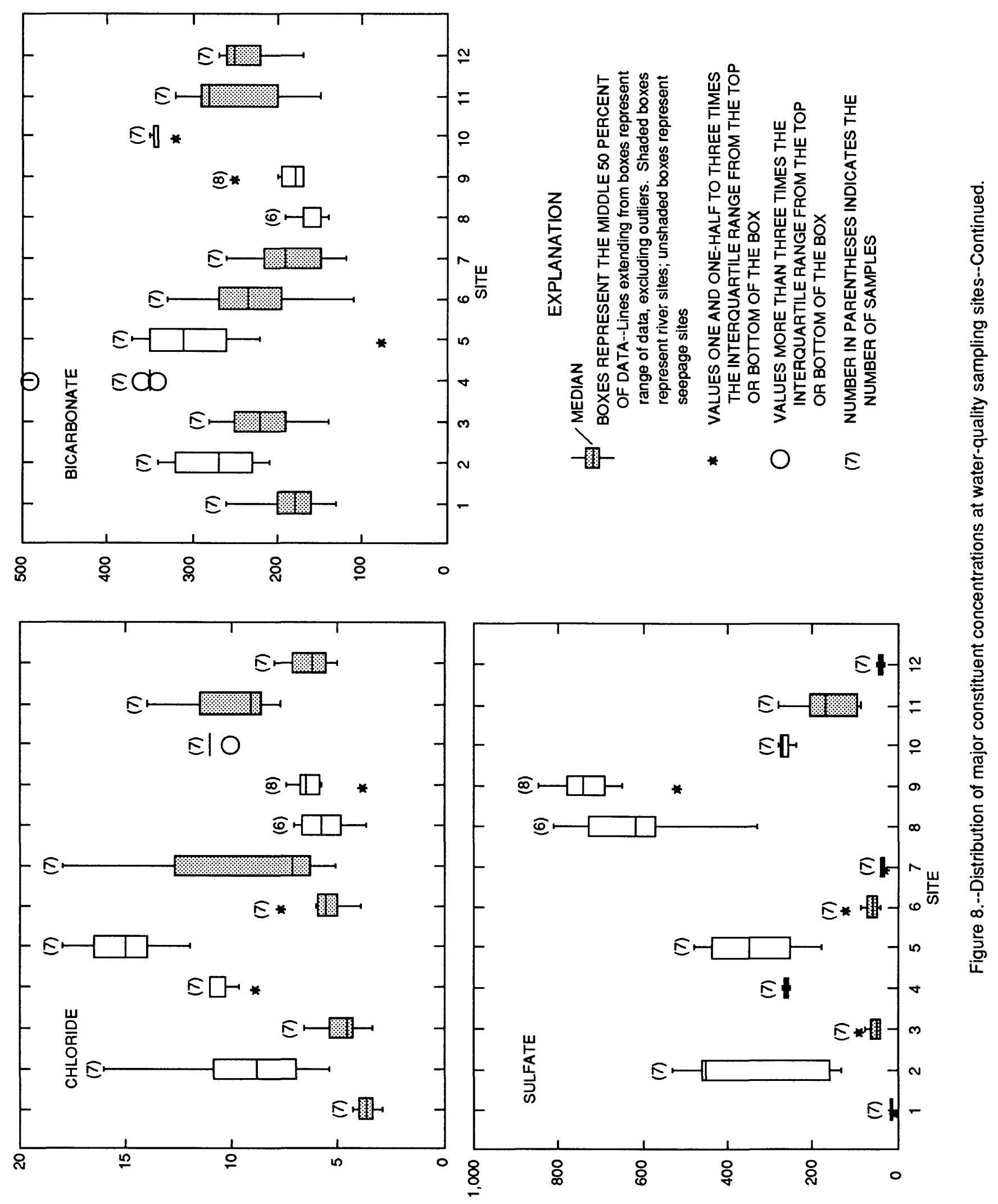

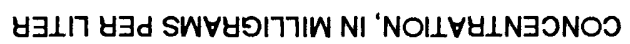


Median calcium concentrations at the river sites were less than $50 \mathrm{mg} / \mathrm{L}$ (milligrams per liter) and median magnesium concentrations were less than $30 \mathrm{mg} / \mathrm{L}$, except for site 11 on the Flat River where the median calcium and magnesium concentrations exceeded 80 and $40 \mathrm{mg} / \mathrm{L}$ (fig. 8). The median potassium concentration for the river sites was between 1 and $3 \mathrm{mg} / \mathrm{L}$, as compared to median potassium concentrations between about 4 and $10 \mathrm{mg} / \mathrm{L}$ for the seepage sites.

Concentrations of sodium and chloride at the Flat River sites were significantly larger than those at the Big River sites (fig. 8). In addition, median concentrations of sodium and chloride at the upstream site on the Flat River (site 7) were larger than those at several seepage sites along the Flat River. Because concentrations of sodium and chloride did not increase between the upstream (site 7) and downstream (site 11) sites on the Flat River as did values of specific conductance and concentrations of calcium and magnesium, substantial quantities of sodium and chloride probably were derived from non-mining sources upstream from the mining areas. A natural source of sodium in the Flat River basin could be feldspar minerals within granitic and volcanic rocks of the St. Francois Mountains that crop out upstream from site 7. More probable sources of increased sodium and chloride concentrations in the Flat River are road salt usage along State Highway 32, which parallels the Flat River for about one-half the distance between the Elvins and National tailings piles, septic systems associated with houses along the Flat River both upstream and downstream from site 7, and discharge from the Flat River sewage treatment facility upstream from the National tailings pile.

Several seepage sites (sites $2,4,5$, and 10 ) contained increased concentrations of sodium and chloride (fig. 8). The source for these increased concentrations is most likely from sources other than mine tailings. Increased sodium and chloride concentrations at site 2 probably are related to effluent from septic systems and a sewage treatment facility upstream from the site. Increased concentrations at site 5 probably are related to sewage effluent from a trailer park upstream from the site. The sodium and chloride concentrations at site 4 were similar to those at site 10 , a seep that contains ground water from the abandoned mines.

The distribution of sulfate concentrations at the river and seepage sites was similar to the distribution of specific conductance values and calcium and magnesium concentrations. Median concentrations of sulfate for the river sites were less than about $80 \mathrm{mg} / \mathrm{L}$, except for site 11 where the median concentration exceeded $150 \mathrm{mg} / \mathrm{L}$ (fig. 8). Significant increases in sulfate concentrations were detected between the upstream site (site 1) on the Big River and the downstream sites (sites 3,6, and 12), indicating mining-related sources. A significant increase in the sulfate concentration also was detected between the upstream site (site 7) and the downstream site (site 11) on the Flat River. Most of this increase can be attributed to the seepage from the Elvins tailings pile. The seepage sites at the Elvins tailings pile had the largest sulfate concentrations of the seepage sites.

Bicarbonate concentrations generally were similar at both the river and seepage sites and ranged from 86 to $490 \mathrm{mg} / \mathrm{L}$ (fig. 8), although the concentrations tended to increase between the upstream (sites 1 and 7) and the downstream (sites 12 and 11) sites on the Big and Flat Rivers. The largest median bicarbonate concentrations were measured at sites 4 and 10. Of the six seepage sites, bicarbonate concentrations were smallest at those sites associated with the Elvins tailings pile (sites 8 and 9).

\section{Trace Elements}

The Missouri Department of Natural Resources (1987) has established criteria for the protection of water quality in the Big River and the Flat River for designated uses. The designated uses of the Big River include protection of aquatic life (general warm-water fishery); livestock and wildlife watering; whole-body-contact recreation; boating and canoeing; and industrial use. Designated uses of the Flat River include protection of aquatic life (limited warm-water fishery) and livestock and wildlife watering. Water-quality criteria for trace elements for these designated uses are 
listed in table 3. Water-quality criteria were exceeded in the Big River and the Flat River during the study period in only one sample from site 11 on the Flat River. In this sample, the lead concentration of $50 \mu \mathrm{g} / \mathrm{L}$ exceeded the water-quality criteria.

Trace elements considered in this study were aluminum, barium, beryllium, cadmium, chromium, cobalt, copper, iron, lead, lithium, manganese, molybdenum, nickel, silver, strontium, vanadium, and zinc. Only dissolved concentrations were determined. Results of all analyses have been reported by Smith and Schumacher (1991).

Several trace elements were not detected in any samples and others were detected in concentrations near the detection limits. The elements not detected and their detection limits are beryllium $(0.5 \mu \mathrm{g} / \mathrm{L})$, chromium $(5 \mu \mathrm{g} / \mathrm{L})$, and vanadium $(6 \mu \mathrm{g} / \mathrm{L})$. Aluminum was detected in one sample $(20 \mu \mathrm{g} / \mathrm{L}$, detection limit of $10 \mu \mathrm{g} / \mathrm{L})$, and copper was detected in one sample $(10 \mu \mathrm{g} / \mathrm{L}$, detection limit of $10 \mu \mathrm{g} / \mathrm{L}$ ). Silver was detected in several samples at concentrations of $2.0 \mu \mathrm{g} / \mathrm{L}$ or less (detection limit of $1.0 \mu \mathrm{g} / \mathrm{L}$ ). Silver is contained in the galena and sphalerite minerals mined in the area, but is more abundant in the sphalerite (Snyder and Gerdemann, 1968).

The largest barium concentrations ( 180 to $380 \mu \mathrm{g} / \mathrm{L}$ ) were detected at site 12 (fig. 9 ), which is less than 10 river mi downstream from the mouth of Mineral Fork (fig. 5). Barium concentrations were less than $125 \mu \mathrm{g} / \mathrm{L}$ at the remainder of the river sites and generally were larger at the river sites than at the seepage sites. Similar barium concentrations were detected in the Big River upstream from Mineral Fork (sites 1, 3, and 6) and in the Flat River (sites 7 and 11), which indicates no detectable effect on barium concentration in these streams from the lead-zinc tailings of the Old Lead Belt.

Cadmium, a common constituent of sphalerite, was detected (detection limit of $1 \mu \mathrm{g} / \mathrm{L}$ ) only at seepage sites 2,8 , and 9 , but most notably at sites 8 and 9 (fig. 9). At those two sites, cadmium concentrations ranged from 14 to $28 \mu \mathrm{g} / \mathrm{L}$.

The distribution of cobalt was similar to that of cadmium (fig. 9). Cobalt was detected only at one river site (site 11 ), and the concentrations were $10 \mu \mathrm{g} / \mathrm{L}$ or less. Large cobalt concentrations were detected, however, at seepage sites 8 and 9 where concentrations ranged from 310 to $610 \mu \mathrm{g} / \mathrm{L}$. Cobalt concentrations at the other seepage sites were less than $100 \mu \mathrm{g} / \mathrm{L}$.

Iron concentrations at all sites were less than $15 \mu \mathrm{g} / \mathrm{L}$. Concentrations of iron in water from river and seepage sites were similar.

Lead concentrations at all sites, except 8,9 , and 11 , were $30 \mu \mathrm{g} / \mathrm{L}$ or less (fig. 9). At sites 8 and 9 , lead concentrations ranged from 10 to $80 \mu \mathrm{g} / \mathrm{L}$. At site 11 , a lead concentration of $50 \mu \mathrm{g} / \mathrm{L}$ was detected 7 days after intense rainfall. This concentration exceeded the Missouri water-quality criteria for lead for the protection of aquatic life.

Lithium concentrations at all sites were less than $25 \mu \mathrm{g} / \mathrm{L}$. Concentrations of lithium larger than $10 \mu \mathrm{g} / \mathrm{L}$ were detected only at seepage sites.

The largest manganese concentrations were detected at sites 2 and 5 . Concentrations at these sites had a considerable range--from less than $50 \mu \mathrm{g} / \mathrm{L}$ to greater than $500 \mu \mathrm{g} / \mathrm{L}$. Manganese concentrations at the rest of the seepage sites were similar (less than $75 \mu \mathrm{g} / \mathrm{L}$ ).

Molybdenum concentrations were $20 \mu \mathrm{g} / \mathrm{L}$ or less at sites 6 and 11 and $10 \mu \mathrm{g} / \mathrm{L}$ or less at all other sites. Molybdenum was detected at six sites. 
Table 3.--Missouri water-quality criteria for the protection of aquatic life and livestock and wildlife watering for the Big River and the Flat River

[Data from the Missouri Department of Natural Resources (1987) and Missouri Department of Natural Resources (written commun., 1989); mg/L, milligrams per liter; <, less than; >, greater than; concentrations of trace elements are in micrograms per liter; chronic toxicity, conditions producing adverse effects over a long period, but having no effect over a short period; acute toxicity, conditions producing adverse effects or lethality in a short period; --, not applicable]

\begin{tabular}{|c|c|c|}
\hline & $\frac{\text { Criteria for protection of aquatic life }(\mu \mathrm{g} / \mathrm{L})^{\mathbf{a}}}{\text { In water with indicated hardness }(\mathrm{mg} / \mathrm{L})}$ & $\begin{array}{l}\text { Criteria for } \\
\text { livestock and }\end{array}$ \\
\hline Trace element & $\begin{array}{lll}<125 & 125-200 & >200\end{array}$ & wildlife watering $(\mu \mathrm{g} / \mathrm{L})^{\mathrm{b}}$ \\
\hline
\end{tabular}

Big River (general warm-water fishery)

Beryllium

Cadmium

Chronic toxicity maximum

Acute toxicity maximum

Chromium

Chronic toxicity maximum

Acute toxicity maximum

Cobalt

Copper

Chronic toxicity maximum

Acute toxicity maximum

Iron

Lead

Chronic toxicity maximum

Acute toxicity maximum

Nickel

Chronic toxicity maximum

Acute toxicity maximum

Silver

Chronic toxicity maximum

Acute toxicity maximum

Zinc

Chronic toxicity maximum

Acute toxicity maximum
5

$\begin{array}{ll}-- & 10\end{array}$

-. 33

13

52

17

72

$\begin{array}{ll}-- & 42 \\ -- & 62\end{array}$

$--\quad 62$

$--$

-. -

20

-- 30

1,000

$\begin{array}{rrr}-- & 12 & 20 \\ -- & 50 & 130 \\ -- & -- & -- \\ -- & 360 & 500 \\ -- & 3,200 & 4,600 \\ & & \\ -- & .12 & -- \\ -- & 4.1 & 8.2 \\ & & \\ -- & 245 & 345 \\ -- & 270 & 380\end{array}$

190

--

650

5,800

37

58

$-$

$-$

380

440

490

200

1,000

500 
Table 3.--Missouri water-quality criteria for the protection of aquatic life and livestock and wildlife watering for the Big River and the Flat River--Continued

\begin{tabular}{|c|c|c|c|c|c|}
\hline Trace element & Criter & $\begin{array}{l}\text { for protect } \\
\text { In water w } \\
<125\end{array}$ & $\frac{\text { of aquatic }}{\text { indicated }}$ & $\frac{\frac{\mathrm{L})^{\mathrm{a}}}{\mathrm{ss}(\mathrm{mg} / \mathrm{L})}}{>200}$ & $\begin{array}{c}\text { Criteria for } \\
\text { livestock and } \\
\text { wildlife watering }(\mu \mathrm{g} / \mathrm{L})^{\mathrm{b}}\end{array}$ \\
\hline \multicolumn{6}{|c|}{ Flat River (limited warm-water fishery) } \\
\hline Beryllium & 5 & -- & -- & -- & - \\
\hline \multicolumn{6}{|l|}{ Cadmium } \\
\hline Chronic toxicity maximum & -. & 13 & 18 & 22 & -- \\
\hline Acute toxicity maximum & -- & 46 & 72 & 100 & - \\
\hline \multicolumn{6}{|l|}{ Chromium } \\
\hline Chronic toxicity maximum & -- & 190 & -- & -- & -- \\
\hline Acute toxicity maximum & -- & 280 & -- & -- & -- \\
\hline Cobalt & -. & -- & -- & -- & 1,000 \\
\hline Copper & -- & -- & -- & -- & 500 \\
\hline Chronic toxicity maximum & -- & 30 & 43 & 55 & -- \\
\hline Acute toxicity maximum & -- & 46 & 67 & 88 & -- \\
\hline Iron & 1,000 & -- & - & -- & -- \\
\hline \multicolumn{6}{|l|}{ Lead } \\
\hline Chronic toxicity maximum & -- & 12 & 20 & 29 & -- \\
\hline Acute toxicity maximum & -- & 50 & 130 & 190 & - \\
\hline Nickel & -- & -- & -- & -- & 200 \\
\hline Chronic toxicity maximum & -- & 425 & 600 & 770 & -- \\
\hline Acute toxicity maximum & -- & 3,800 & 5,400 & 6,900 & -- \\
\hline \multicolumn{6}{|l|}{ Silver } \\
\hline Chronic toxicity maximum & -- & .12 & -- & -- & -- \\
\hline Acute toxicity maximum & -- & 4.1 & 8.2 & 13 & -- \\
\hline \multicolumn{6}{|l|}{ Zinc } \\
\hline Chronic toxicity maximum & -- & 1,065 & 1,505 & 1,920 & -- \\
\hline Acute toxicity maximum & .. & 1,180 & 1,660 & 2,120 & .- \\
\hline
\end{tabular}

a Approved analytical methods are either dissolved or total recoverable, except the method for iron and copper, which is dissolved.

b Approved analytical method is total. 

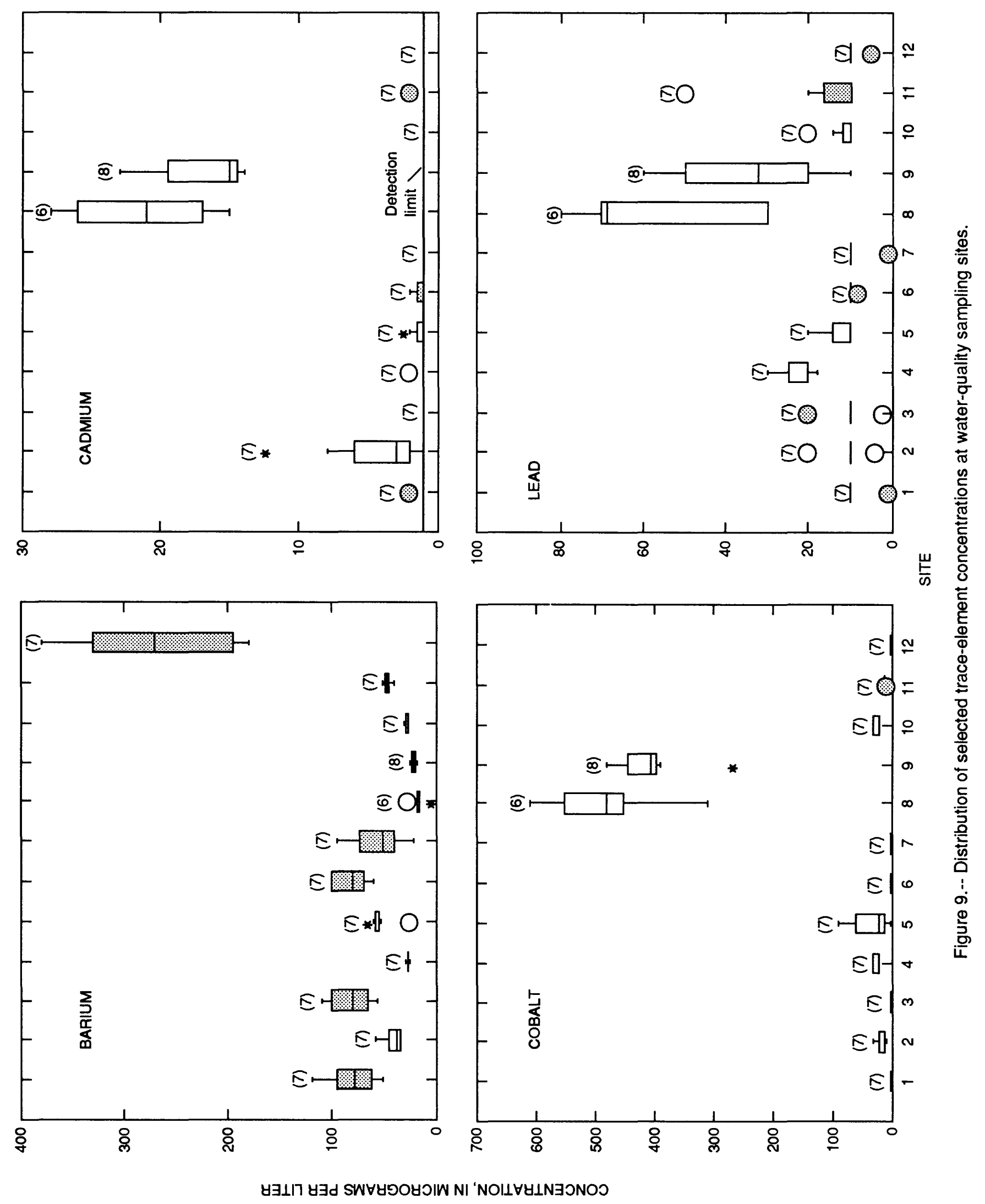

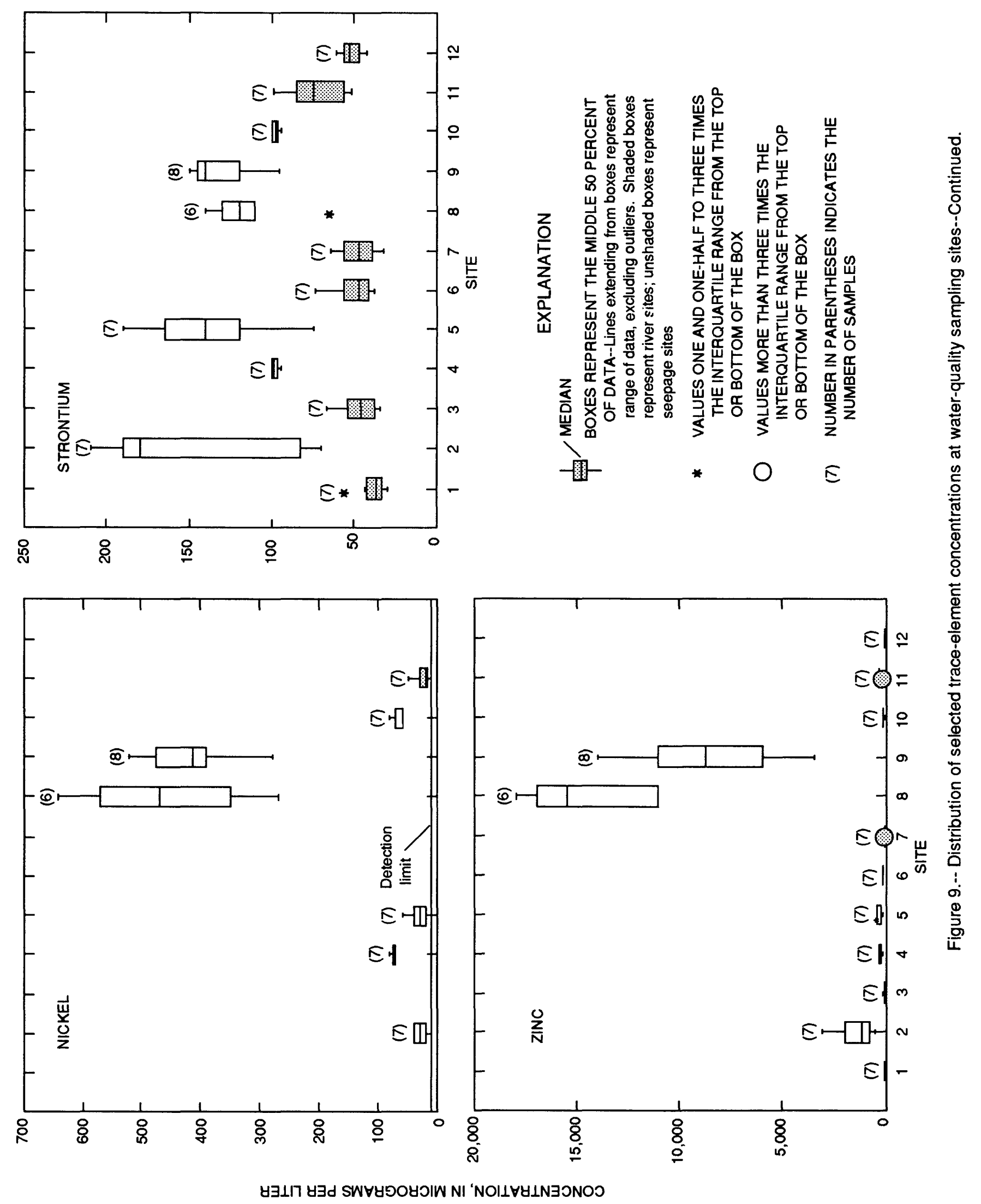
Nickel concentrations ranged from 10 to $50 \mu \mathrm{g} / \mathrm{L}$ at site 11 and were $10 \mu \mathrm{g} / \mathrm{L}$ or less for all other river sites (fig. 9). Nickel concentrations generally were largest at seepage sites; the largest concentrations were at sites 8 and 9 . Nickel concentrations at these two sites ranged from 270 to $640 \mu \mathrm{g} / \mathrm{L}$. Site $4(70$ to $80 \mu \mathrm{g} / \mathrm{L})$ and site $10(60$ to $80 \mu \mathrm{g} / \mathrm{L})$ had similar nickel concentrations.

Strontium concentrations were similar to calcium concentrations at all sites except sites 4,8 , and 9. At these sites, strontium concentrations were significantly less than the calcium concentrations. Strontium concentrations equal to or larger than $100 \mu \mathrm{g} / \mathrm{L}$ were detected at all seepage sites and exceeded $200 \mu \mathrm{g} / \mathrm{L}$ at site 2 (fig. 9).

Zinc concentrations for all river sites, except site 11 , were less than or equal to $160 \mu \mathrm{g} / \mathrm{L}$. Zinc concentrations at site 11 ranged from 110 to $400 \mu \mathrm{g} / \mathrm{L}$. The larger zinc concentrations at site 11 can be attributed primarily to inflow from the Elvins tailings pile. Seepage sites at the Elvins pile (sites 8 and 9) had the largest zinc concentrations of all sites. Zinc concentrations ranged from 11,000 to 18,000 $\mu \mathrm{g} / \mathrm{L}$ at site 8 and ranged from 3,500 to $14,000 \mu \mathrm{g} / \mathrm{L}$ at site 9 . Zinc concentrations at site 10 were less than $165 \mu \mathrm{g} / \mathrm{L}$. Zinc concentrations ranged from 550 to $3,100 \mu \mathrm{g} / \mathrm{L}$ at site 2 and from 120 to $740 \mu \mathrm{g} / \mathrm{L}$ at site 5 .

\section{Relations Between Selected Constituents}

Regression analysis indicated a positive correlation between zinc and cadmium concentrations $\left(r^{2}=0.92\right)$ in water samples collected at seepage sites (fig. 10). No cadmium minerals have been detected in the Old Lead Belt, but this relation is to be expected because sphalerite commonly contains about 1 percent cadmium in solid solution (Snyder and Gerdemann, 1968). The six points that are below the trend of the regression in figure 10 are for samples from sites 2 and 9 . According to Davis (1960), the largest cadmium values occur near the main central fault system of the Federal fault (fig. 3 ) and decrease gradually outward from the fault. This could explain in part the increased cadmium values in relation to zinc at site 9.

A positive correlation was detected between zinc and sulfate $\left(r^{2}=0.74 ;\right.$ fig. 11$)$. Zinc and sulfate were not normally distributed and, therefore, logarithms of constituent concentration were used in the regression analysis. The points in the shaded area of figure 11 represent sites 4,5 , and 10 . These sites contained larger than expected concentrations of sulfate in relation to zinc. This could be related to oxidation of sulfide minerals other than sphalerite, such as pyrite, marcasite, and galena, or preferential removal of zinc by precipitation or sorption reactions.

Two relations were noted using data collected at sites 1 and 12 on the Big River (fig. 12). The first relation is the tendency of zinc to increase with increasing discharge. Increases in constituent concentration with discharge are unusual because concentrations generally decrease from the effects of dilution. Zinc concentrations were largest at site 6 downstream from much of the mined area and decreased downstream in the Big River at site 12 . The second relation is between zinc and sulfate, two of the more soluble mining-related constituents (fig. 12). The plot of these constituents at sites 1 and 12 reflect the similar source of both constituents because they are related to oxidation of sulfide minerals, such as sphalerite, in the mining area.

\section{Water Quality During Periods of High Flow}

Water samples were collected at gaging stations on the Big River and the Flat River (sites 6 and 11) within the mined area during several high-flow events. Only during one event (September 1988) were samples collected at both sites. Analytical results of these samples have been documented by Smith and Schumacher (1991). Physical properties and selected constituent concentrations for quarterly and high-flow samples are listed in table 4. 


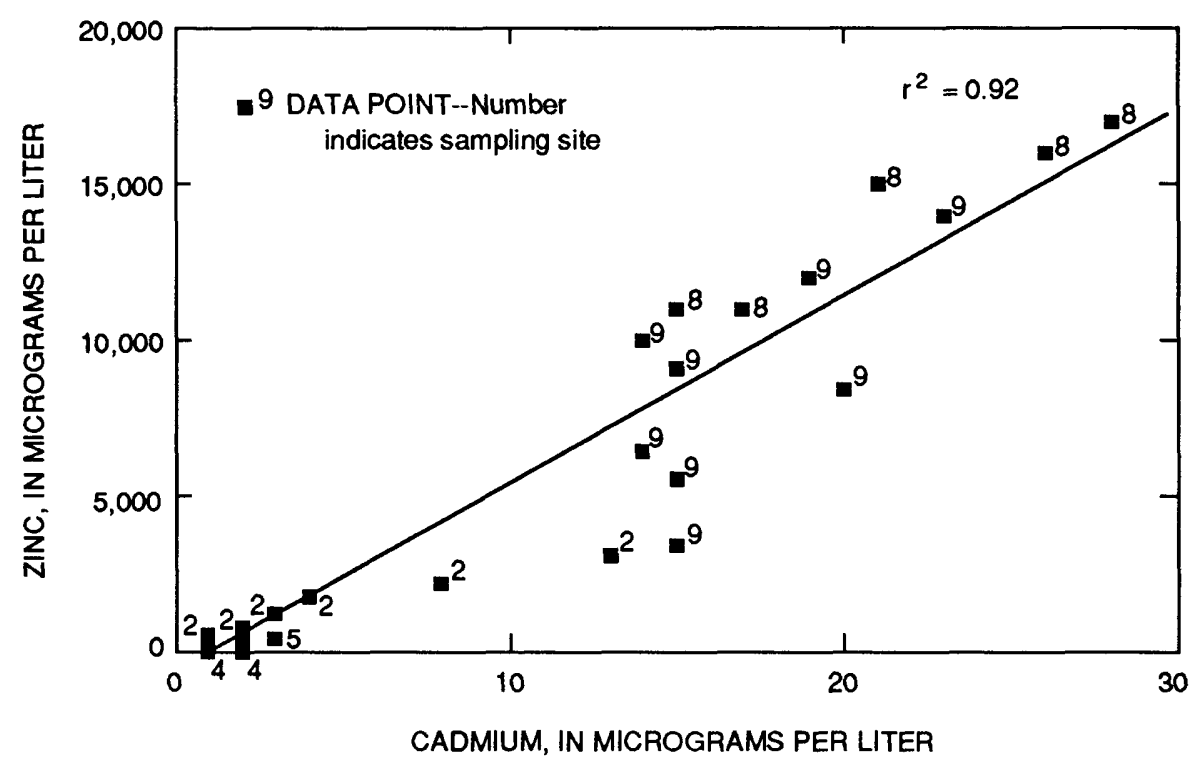

Figure 10.--Relation between dissolved zinc and cadmium at seepage sites.

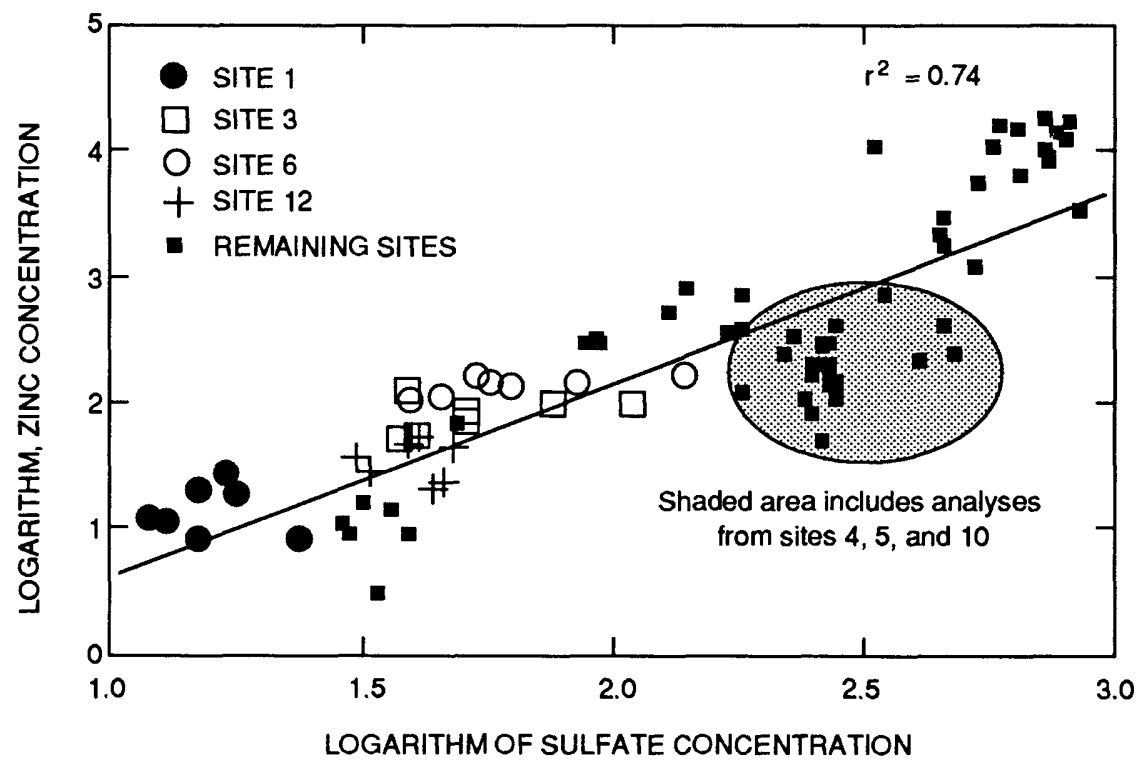

Figure 11.--Relation between dissolved zinc and sulfate at water-quality sampling sites. 

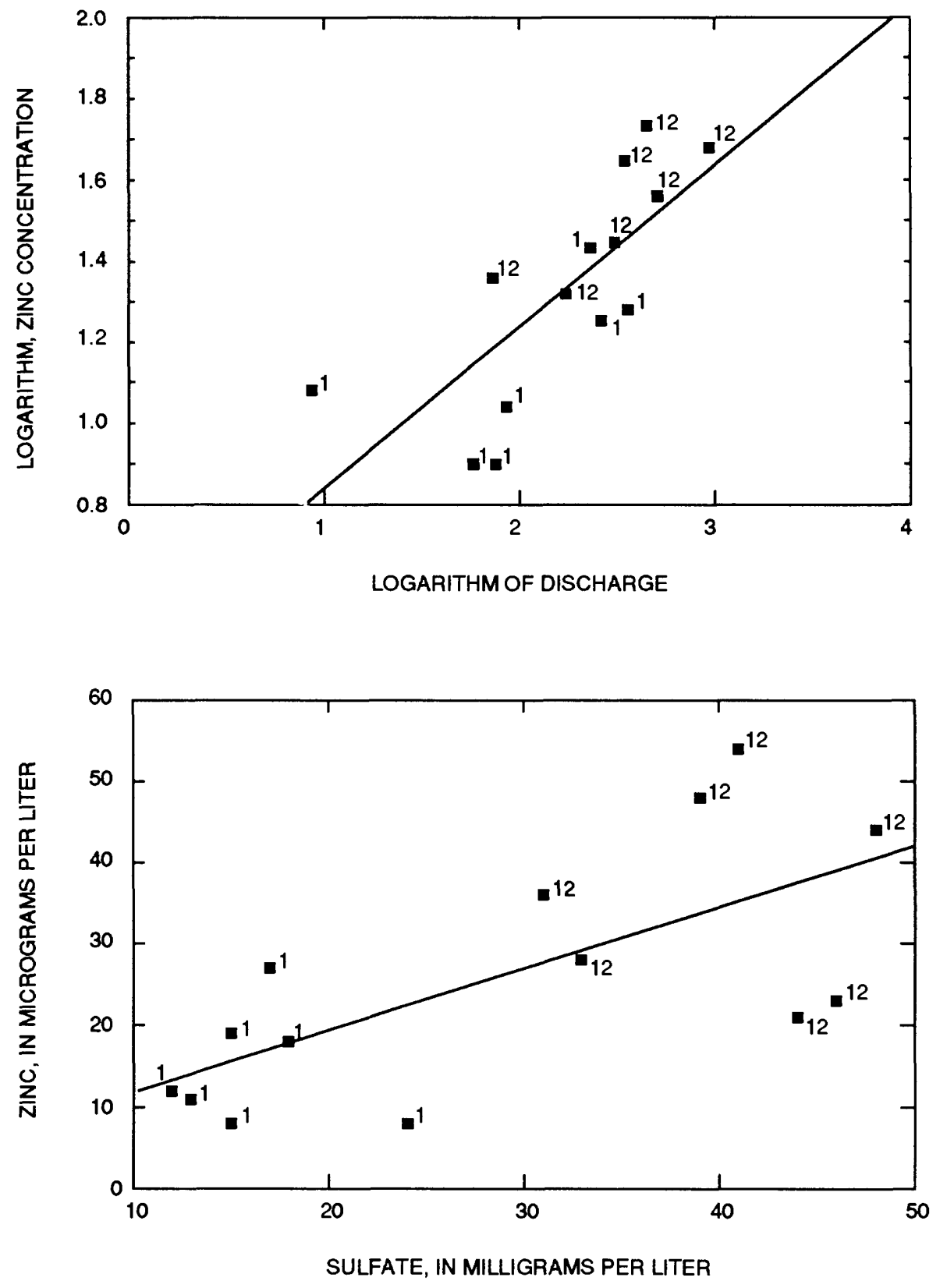

EXPlanAtion
-1 SITE AND NuMber

Figure 12.--Relation between selected properties and constituents at sites 1 and 12. 
Table 4.--Physical properties and selected constituent concentrations for quarterly and high-flow samples

$\left[\mathrm{ft}^{3} / \mathrm{s}\right.$, cubic feet per second; $\mu \mathrm{S} / \mathrm{cm}$, microsiemens per centimeter at 25 degrees Celsius; mg/L, milligrams per liter; ${ }^{\circ} \mathrm{C}$, degrees Celsius; $\mu \mathrm{g} / \mathrm{L}$, micrograms per liter; $<$, less than; trace-element concentrations are dissolved]

\begin{tabular}{|c|c|c|c|c|c|c|}
\hline & Median of & & & h-flow sam & & \\
\hline $\begin{array}{c}\text { Property or constituent } \\
\text { and unit of measurement }\end{array}$ & $\begin{array}{l}\text { quarterly samples } \\
\text { eb. 1988-Sept. 1989) }\end{array}$ & $\begin{array}{l}9-18-88 \\
\text { at } 1945\end{array}$ & $\begin{array}{l}9-19-88 \\
\text { at } 0830\end{array}$ & $\begin{array}{l}2-14-89 \\
\text { at } 1230\end{array}$ & $\begin{array}{l}2-14-89 \\
\text { at } 1430\end{array}$ & $\begin{array}{l}6-19-89 \\
\text { at } 1145\end{array}$ \\
\hline & & Site 6 & & & & \\
\hline Discharge, $\mathrm{ft}^{3} / \mathrm{s}$ & 131 & 540 & 720 & 3,190 & 2,670 & 944 \\
\hline Specific conductance, $\mu \mathrm{S} / \mathrm{cm}$ & 504 & 390 & 185 & 142 & 152 & 261 \\
\hline $\mathrm{pH}$, standard units & 7.9 & 7.8 & 7.6 & 8.2 & 8.0 & 7.7 \\
\hline Hardness as $\mathrm{CaCO}_{3}, \mathrm{mg} / \mathrm{L}$ & 230 & 170 & 88 & 72 & 63 & 130 \\
\hline Hardness, noncarbonate, $\mathrm{mg} / \mathrm{L}$ & 51 & 52 & 18 & 4 & 0 & 25 \\
\hline Calcium, mg/L & 48 & 35 & 19 & 15 & 13 & 28 \\
\hline Magnesium, mg/L & 27 & 21 & 9.8 & 8.3 & 7.3 & 15 \\
\hline Sodium, mg/L & 3.9 & 3.4 & 1.9 & 1.7 & 1.5 & 2.3 \\
\hline Potassium, mg/L & 1.9 & 2.6 & 3.9 & 1.7 & 1.2 & 1.9 \\
\hline Bicarbonate, $\mathrm{mg} / \mathrm{L}$ & 235 & 150 & 85 & 83 & 87 & 130 \\
\hline Alkalinity, $\mathrm{mg} / \mathrm{L}$ as $\mathrm{CaCO}_{3}$ & 197 & 122 & 70 & 68 & 72 & 107 \\
\hline Sulfate, mg/L & 57 & 65 & 17 & 16 & 17 & 15 \\
\hline Chloride, $\mathrm{mg} / \mathrm{L}$ & 5.6 & 4.9 & 3.6 & 2.3 & 2.4 & 2.9 \\
\hline Silica, $\mathrm{mg} / \mathrm{L}$ & 5.7 & 5.2 & 5.7 & 6.6 & 7.3 & 7.8 \\
\hline $\begin{array}{l}\text { Dissolved solids, } \\
\text { residue at } 180^{\circ} \mathrm{C}, \mathrm{mg} / \mathrm{L}\end{array}$ & 254 & 209 & 109 & 98 & 95 & 153 \\
\hline Dissolved solids, calculated & 259 & 211 & 103 & 93 & 93 & 138 \\
\hline Aluminum, $\mu \mathrm{g} / \mathrm{L}$ & $<10$ & $<10$ & $<10$ & 110 & 40 & 20 \\
\hline Barium, $\mu \mathrm{g} / \mathrm{L}$ & 81 & 56 & 59 & 31 & 31 & 83 \\
\hline Iron, $\mu \mathrm{g} / \mathrm{L}$ & $<10$ & 18 & 27 & 120 & 67 & 40 \\
\hline Lead, $\mu \mathrm{g} / \mathrm{L}$ & $<10$ & $<10$ & $<10$ & $<10$ & $<10$ & $<10$ \\
\hline Manganese, $\mu \mathrm{g} / \mathrm{L}$ & 33 & 15 & 3 & 38 & 16 & 12 \\
\hline Strontium, $\mu \mathrm{g} / \mathrm{L}$ & 47 & 36 & 21 & 22 & 19 & 33 \\
\hline Zinc, $\mu \mathrm{g} / \mathrm{L}$ & 140 & 29 & 26 & 74 & 56 & 26 \\
\hline
\end{tabular}


Table 4.--Physical properties and constituent concentrations for quarterly and high-flow samples--Continued

\begin{tabular}{|c|c|c|c|c|}
\hline \multirow[b]{2}{*}{$\begin{array}{l}\text { Property or constituent } \\
\text { and unit of measurement }\end{array}$} & \multirow{2}{*}{$\begin{array}{c}\text { Median of } \\
\text { quarterly samples } \\
\text { (Feb. 1988-Sept. 1989) }\end{array}$} & \multicolumn{3}{|c|}{ High-flow samples } \\
\hline & & $\begin{array}{l}9-18-88 \\
\text { at } 1715 \\
\end{array}$ & $\begin{array}{l}3-20-89 \\
\text { at } 1230 \\
\end{array}$ & $\begin{array}{l}3-20-89 \\
\text { at } 1445\end{array}$ \\
\hline \multicolumn{5}{|c|}{ Site 11} \\
\hline Discharge, $\mathrm{ft}^{3} / \mathrm{s}$ & 7.4 & 420 & 159 & 276 \\
\hline Specific conductance, $\mu \mathrm{S} / \mathrm{cm}$ & 732 & 140 & 350 & 275 \\
\hline $\mathrm{pH}$, standard units & 7.6 & 7.8 & 7.9 & 7.6 \\
\hline Hardness as $\mathrm{CaCO}_{3}, \mathrm{mg} / \mathrm{L}$ & 380 & 60 & 170 & 130 \\
\hline Hardness, noncarbonate, $\mathrm{mg} / \mathrm{L}$ & 170 & 22 & 33 & 22 \\
\hline Calcium, mg/L & 80 & 13 & 35 & 26 \\
\hline Magnesium, mg/L & 44 & 6.6 & 19 & 15 \\
\hline Sodium, mg/L & 9.4 & 3.0 & 6.0 & 4.0 \\
\hline Potassium, $\mathrm{mg} / \mathrm{L}$ & 2.6 & 4.3 & 1.8 & 1.6 \\
\hline Bicarbonate, $\mathrm{mg} / \mathrm{L}$ & 280 & 46 & 160 & 130 \\
\hline Alkalinity, $\mathrm{mg} / \mathrm{L}$ as $\mathrm{CaCO}_{3}$ & 229 & 38 & 133 & 105 \\
\hline Sulfate, $\mathrm{mg} / \mathrm{L}$ & 170 & 20 & 59 & 39 \\
\hline Chloride, $\mathrm{mg} / \mathrm{L}$ & 9.1 & 4.2 & 7.3 & 5.5 \\
\hline Silica, mg/L & 6.4 & 4.9 & 4.8 & 5.9 \\
\hline $\begin{array}{l}\text { Dissolved solids, } \\
\text { residue at } 180^{\circ} \mathrm{C}, \mathrm{mg} / \mathrm{L}\end{array}$ & 488 & 86 & 200 & 161 \\
\hline Dissolved solids, calculated & 447 & 79 & 213 & 160 \\
\hline Aluminum, $\mu \mathrm{g} / \mathrm{L}$ & $<10$ & 10 & $<10$ & 20 \\
\hline Barium, $\mu \mathrm{g} / \mathrm{L}$ & 47 & 36 & 38 & 32 \\
\hline Iron, $\mu \mathrm{g} / \mathrm{L}$ & $<10$ & 65 & 17 & 36 \\
\hline Lead, $\mu \mathrm{g} / \mathrm{L}$ & $<10$ & 10 & 20 & 30 \\
\hline Manganese, $\mu \mathrm{g} / \mathrm{L}$ & 26 & 12 & 37 & 28 \\
\hline Strontium, $\mu \mathrm{g} / \mathrm{L}$ & 75 & 16 & 38 & 30 \\
\hline Zinc, $\mu \mathrm{g} / \mathrm{L}$ & 330 & 20 & 91 & 63 \\
\hline
\end{tabular}


At site 6, values of $\mathrm{pH}$ and specific conductance and concentrations of most constituents in high-flow samples generally were less than median values for samples collected quarterly (table 4). However, the $\mathrm{pH}$ values for the two largest discharges (February 14, 1989, at 1230 and 1430 hours) were larger than the median values for the quarterly samples. Major constituent concentrations in most high-flow samples were less than the median concentrations for the quarterly samples, except for potassium concentrations. Also, the sulfate concentration was larger in the high-flow sample of September 18, 1988, the smallest of the sampled high-flow events, than the median concentration of the quarterly samples. Sulfate concentrations in the rest of the high-flow samples collected at site 6 were less than (only about one-fourth) the median value of the quarterly samples. Trace-element concentrations in the high-flow samples were less than the median concentrations for the quarterly samples, except for aluminum, iron, barium, and manganese. The barium concentration in the high-flow sample of June 19, 1989, and the manganese concentration in the high-flow sample of February 14, 1989, at 1230 hours (the largest measured discharge), were larger than the median concentrations for quarterly samples. Aluminum and iron concentrations in all high-flow samples were larger than the median concentrations in quarterly samples. Lead concentrations were less than $10 \mu \mathrm{g} / \mathrm{L}$, and zinc concentrations were less than $75 \mu \mathrm{g} / \mathrm{L}$ in the high-flow samples at site 6 .

At site 11 on the Flat River, specific conductance values and major constituent concentrations in high-flow samples (except one potassium concentration in the high-flow sample of September 18, 1988, at 1715 hours) were less than the median for the quarterly samples. Trace-element concentrations in the high-flow samples were less than the median for the quarterly samples, except for concentrations of aluminum, iron, and manganese. Concentrations of these three elements generally were larger in the high-flow samples than in the quarterly samples.

\section{Comparison of Instantaneous Constituent Loads}

The effects of seepage from tailings piles on the quality of water in the Big River or the Flat River is largely a function of the loads of constituents contributed to the river by seepage. To assess the effects of seepage from tailings piles, the instantaneous loads of sulfate, dissolved solids, and zinc at each sampling site were compared. The following equations were used to compute instantaneous loads in grams per second for selected constituents: the first equation was used for sulfate and dissolvedsolids concentrations in milligrams per liter; the second was used for zinc concentrations in micrograms per liter.

$$
\begin{aligned}
& \mathrm{LDC}_{\mathrm{i}}=\mathrm{C}_{\mathrm{i}} \mathrm{mg} / \mathrm{L} \times \frac{1 \mathrm{~g}}{1,000 \mathrm{mg}} \times\left(\mathrm{Q}_{\mathrm{i}} \mathrm{ft}^{3} / \mathrm{s} \times 28.317 \text { liter/ft } \mathrm{f}^{3}\right) \\
& \mathrm{LDC}_{\mathrm{i}}=\mathrm{C}_{\mathrm{i}} \mu \mathrm{g} / \mathrm{L} \times \frac{1 \mathrm{~g}}{1,000,000 \mu \mathrm{g}} \times\left(\mathrm{Q}_{\mathrm{i}} \mathrm{ft}^{3} / \mathrm{s} \times 28.317 \text { liter } / \mathrm{ft}^{3}\right)
\end{aligned}
$$

where $\mathrm{LDC}_{\mathrm{i}}$ is the instantaneous constituent load in grams per second, $\mathrm{C}_{\mathrm{i}}$ is the reported constituent concentration, and $Q_{i}$ is the instantaneous discharge in cubic feet per second.

The instantaneous sulfate load increased significantly downstream in the Big River. Sulfate loads increased from site 1 to site 3 , remained unchanged from site 3 to site 6 , and increased from site 6 to site 12 (fig. 13). At site 12, the load was about twice as large as the load at site 6 . The larger loads at site 12 indicated additional sources of sulfate, probably from the Flat River and Mineral Fork.

The instantaneous load for dissolved solids also increased downstream, as did sulfate (fig. 13); however, increases in dissolved-solids loads between sites 1 and 3 were not significant. The loads at sites 3 and 6 were approximately equal, but a significant increase in the dissolved-solids load occurred between site 6 and site 12. The large outlier at site 12 (fig. 13) for both sulfate and dissolved solids reflects the unusually large discharge for this sample $\left(948 \mathrm{ft}^{3} / \mathrm{s}\right)$ as compared with discharge from other samples (less than $510 \mathrm{ft}^{3} / \mathrm{s}$ ). 

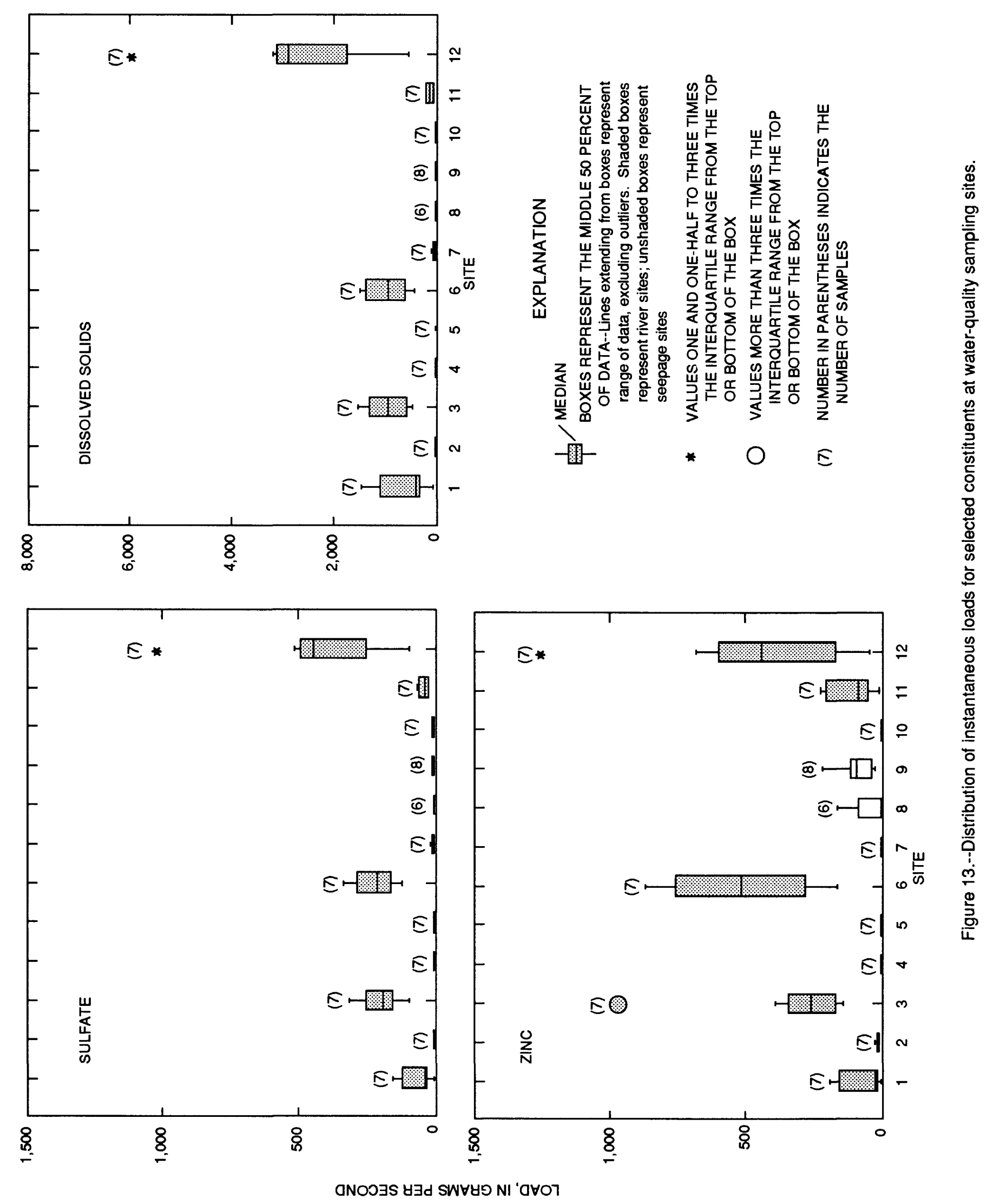
Instantaneous loads for zinc significantly increased downstream within and just downstream from the mining area. In the Big River, zinc loads significantly increased from site 1 to sites 3 and 6 . The apparent slight decrease at site 12 may be related to removal of zinc from solution by geochemical reactions, such as precipitation or sorption.

Instantaneous loads of sulfate, dissolved solids, and zinc significantly increased between site 7 and site 11 on the Flat River (fig. 13). The increase in sulfate and dissolved-solids loads was relatively small, but the increase in the zinc load was larger and similar to loads at sites 8 and 9, indicating that the zinc load at site 11 largely reflects the load contributed by seepage inflow from the Elvins tailings pile. The zinc loads at seepage sites 2,5 , and 10 were small when compared with the other sites in the study area.

\section{SURFACE- AND GROUND-WATER RELATIONS}

About 100,000 drill holes were drilled in the area of the Old Lead Belt (Snyder and Gerdemann, 1968), and, at the time of this study, many of these holes remained unplugged, which enabled ground water to reach land surface where the land surface is lower than the regional potentiometric surface. Most of the drill holes at an altitude of less than about $730 \mathrm{ft}$ are flowing at land surface. This indicates a regional potentiometric surface in the area of about $730 \mathrm{ft}$ or greater. This is supported by a predevelopment potentiometric-surface map prepared by Imes (1990), which shows the potentiometric surface ranges from 700 to $800 \mathrm{ft}$ in the mined area. During the study, water was observed flowing from some of the drill holes in the area. To understand the effects of these mining related discharges on the surface-water regime, seepage runs were conducted in the study area. In this section, results of the seepage runs are discussed in relation to the sources and quality of inflow into the Big River and the Flat River.

\section{Seepage Runs on the Big River and the Flat River}

Seepage runs, which consisted of numerous discharge measurements in a stream reach to monitor seepage into or out of the reach, were conducted in segments on the Big River and the Flat River in September and November 1989. Seepage runs on the Big River from about 1 river mi upstream from Highway 8 (site A; fig. 14) to the Leadwood Public Access (site H) and on the Flat River from Derby (site 7; fig. 15) to the gaging station downstream from the National tailings pile (site 11) were made September 13-14, 1989 (fig. 15). The seepage run on the Big River from the Leadwood Public Access (site $\mathrm{H}$ ) to the gaging station downstream from the Desloge tailings pile (site 6) was completed November 6-8, 1989 (fig. 16). Sites identified with letters in figures 14 through 16 are sites for which water-quality data were collected only during the seepage runs (Smith and Schumacher, 1991); sites identified with numbers are quarterly sampling sites, and sites with no letter or number are sites for which discharge and specific conductance measurements were made only during the

seepage runs. Seepage runs were made during high base-flow conditions, about one and one-half to three times greater than the 7-day 2-year low flow (Skelton, 1976). No rain had fallen during the 2 to 3 weeks before each seepage run. The results of the seepage runs have been reported by Smith and Schumacher (1991). Most discharge measurements made during the seepage runs were rated as good and were considered accurate to within 5 percent. Estimated discharge values for some sites probably are accurate to within 15 percent.

The Big River throughout its entire length is classified as a gaining stream (Missouri Department of Natural Resources, 1986). During the first part of the seepage run on the Big River, discharge from site A to site $E$ (fig. 14), which is upstream from the mouth of Eaton Creek, remained relatively constant, ranging from 21 to $22 \mathrm{ft}^{3} / \mathrm{s}$. Several intermittent tributaries are located in this reach of the Big River, but most had no flow. Discharge from those tributaries with flow was generally less than $0.05 \mathrm{ft}^{3} / \mathrm{s}$. Specific conductance values throughout this reach of the Big River increased only slightly from 400 to $460 \mu \mathrm{S} / \mathrm{cm}$. 


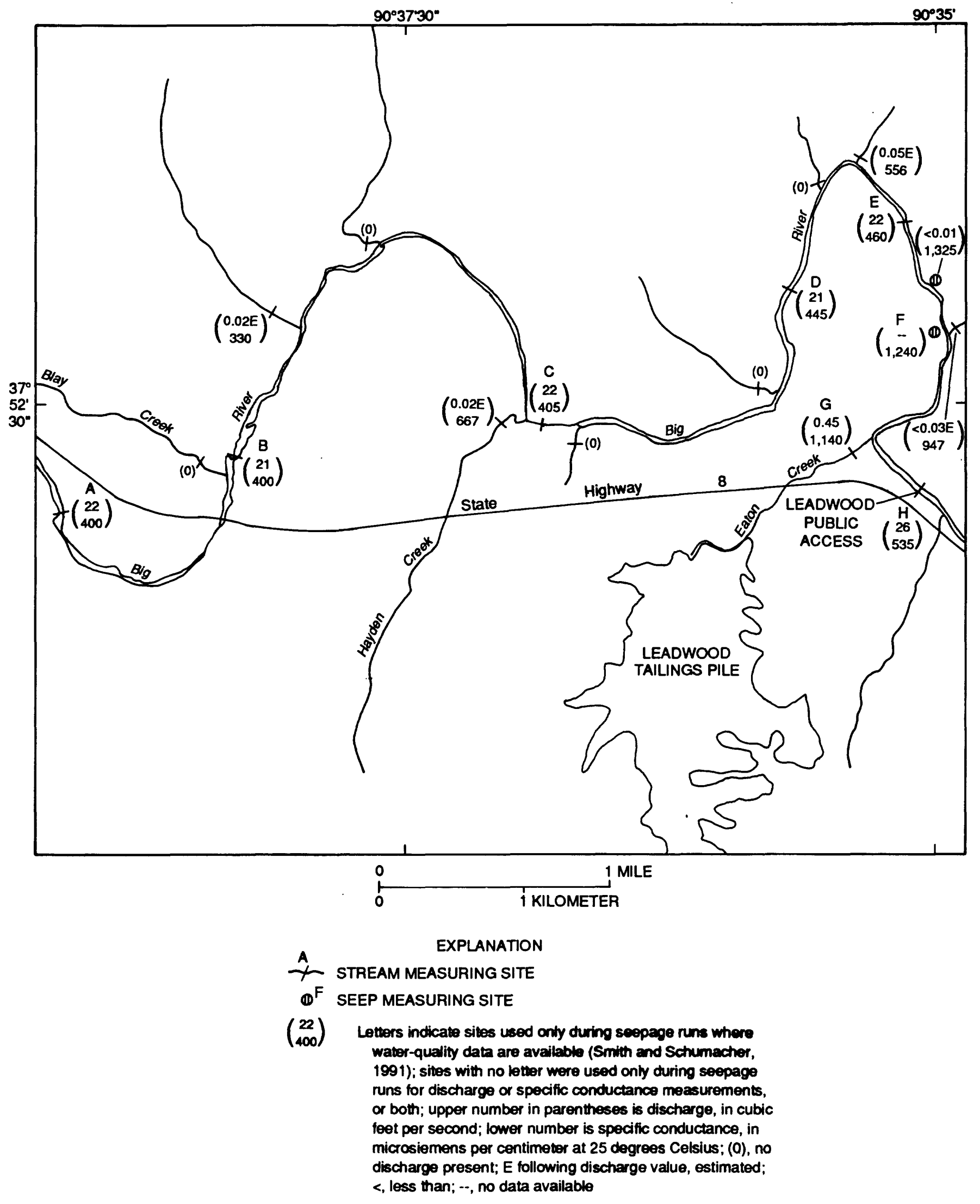

Figure 14.--Results of seepage run on the Big River, September 13, 1989. 


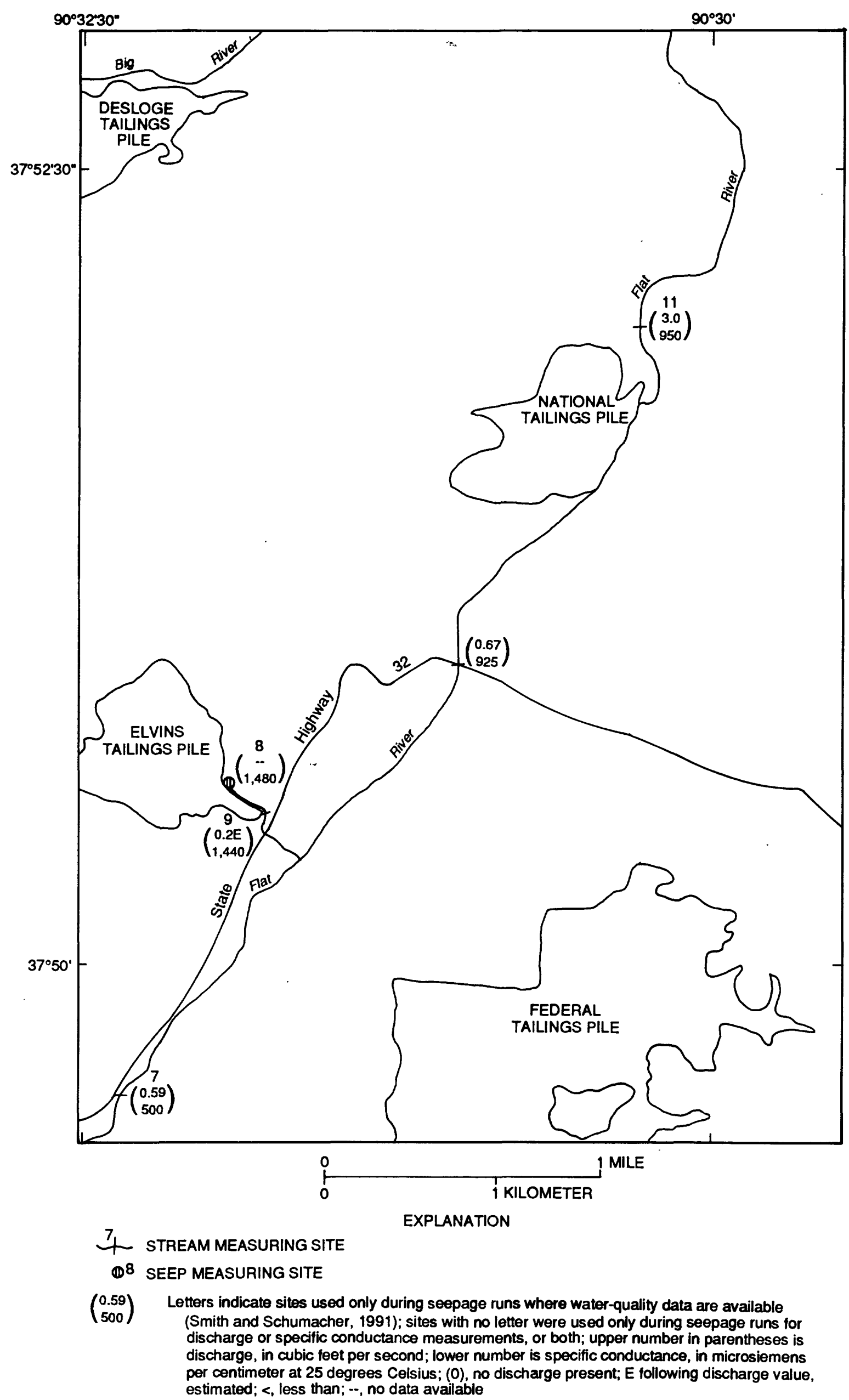

Figure 15.--Results of seepage run on the Flat River, September 13, 1989. 


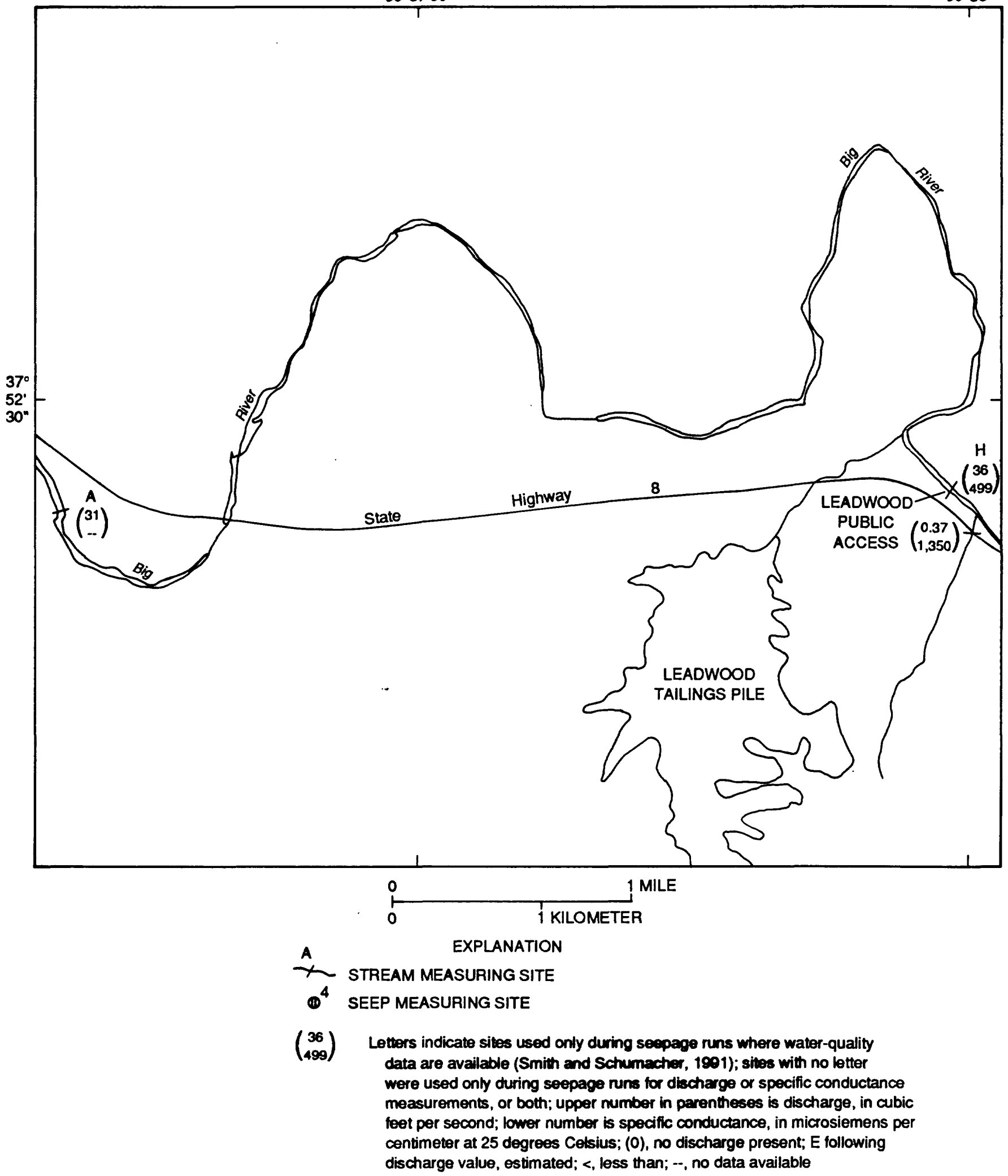

Figure 16.--Results of seepage run on the Big River, November 6-8, 1989. 


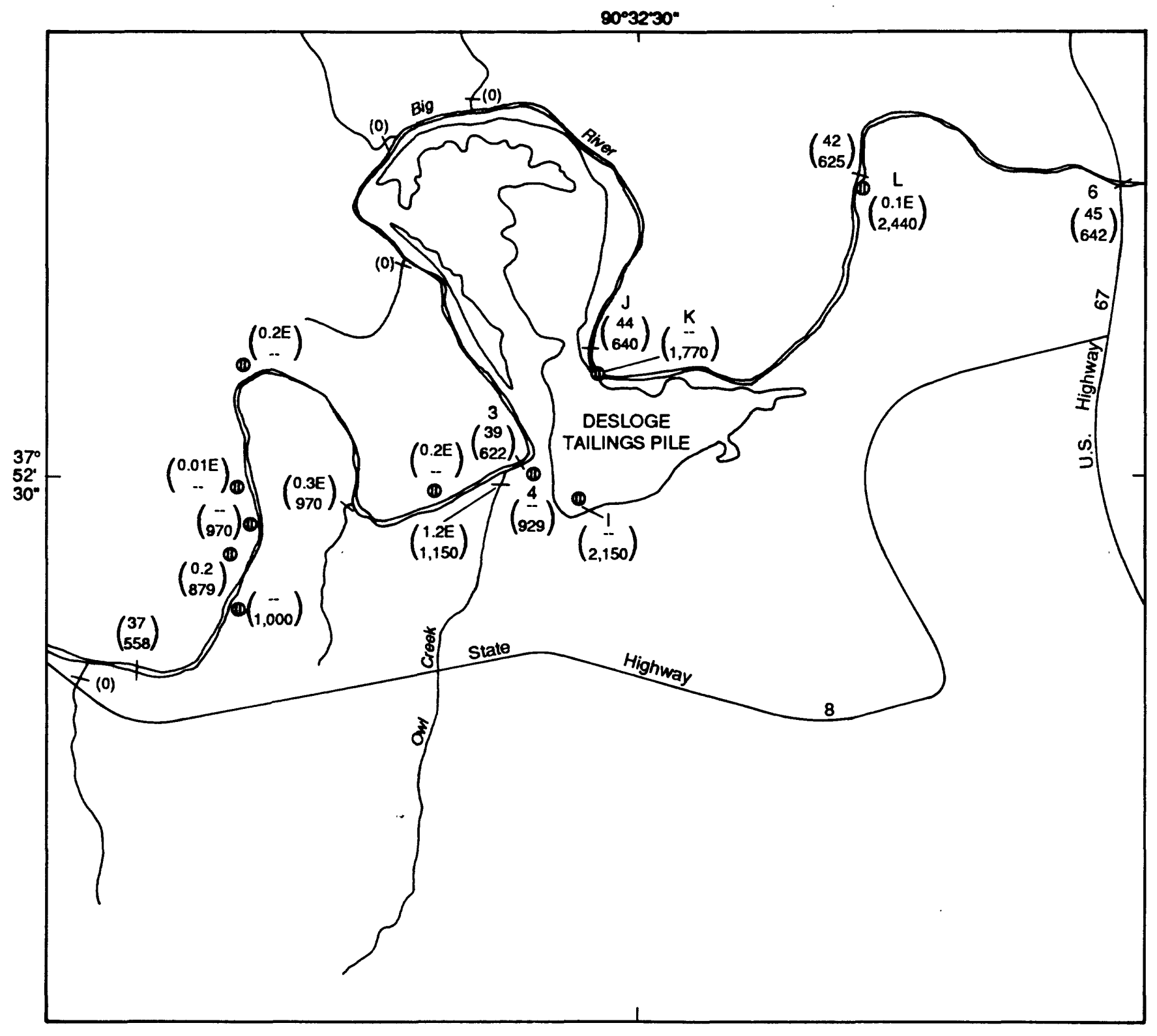

Figure 16.--Results of seepage run on the Big River, November 6-8, 1989--Continued. 
From site $\mathbf{E}$ to the Leadwood Public Access (site H), flow and specific conductance increased. Flow increased about 20 percent from 22 to $26 \mathrm{ft}^{3} / \mathrm{s}$. The inflow from ground-water sources, mostly abandoned drill holes, and tributaries measured less than $0.5 \mathrm{ft}^{3} / \mathrm{s}$, indicating a net gain of $3.5 \mathrm{ft}^{3} / \mathrm{s} \mathrm{in}$ the Big River from ground-water infiltration through the streambed. Specific conductance values increased from $460 \mu \mathrm{S} / \mathrm{cm}$ at site $\mathrm{E}$ to $535 \mu \mathrm{S} / \mathrm{cm}$ at site $\mathrm{H}$. Specific conductance values of measured ground-water sources, such as water flowing from abandoned drill holes, were about two and one-half times the specific conductances of water in the Big River. Eaton Creek (site G), which contributes flow to the Big River, contained seepage from the Leadwood tailings pile and had a specific conductance value of $1,140 \mu \mathrm{S} / \mathrm{cm}$.

The Flat River is considered to be a gaining stream in some reaches (Missouri Department of Natural Resources, 1986) and an intermittent stream in other reaches (Kramer, 1976). Discharge in the river remained fairly constant from site 7 to the site at Highway 32, which is about 1 river mi downstream from the Elvins tailings pile. Discharge downstream from the Highway 32 site to site 11 increased about $2.3 \mathrm{ft}^{3} / \mathrm{s}$--from 0.67 to $3.0 \mathrm{ft}^{3} / \mathrm{s}$. Discharge from the seep from the National tailings pile (which was not measured during the seepage run) ranged from about 0.5 to $1.5 \mathrm{ft}^{3} / \mathrm{s}$ during the study period and cannot account for all of the additional $2.3 \mathrm{ft}^{3} / \mathrm{s}$ of discharge. No other tributaries were measured during the seepage run. However, discharge from the Flat River sewage treatment facility upstream from the National tailings pile could be entering the Flat River.

Specific conductance in the Flat River increased from $500 \mu \mathrm{S} / \mathrm{cm}$ at site 7 to $925 \mu \mathrm{S} / \mathrm{cm}$ at the site at Highway 32. Much of this increase can be attributed to inflow from the Elvins tailings pile, which had a specific conductance of $1,440 \mu \mathrm{S} / \mathrm{cm}$. The specific conductance increased only slightly from $925 \mu \mathrm{S} / \mathrm{cm}$ at the site at Highway 32 to $950 \mu \mathrm{S} / \mathrm{cm}$ at site 11 . Seepage from the National tailings pile, which had a specific conductance of 900 to $962 \mu \mathrm{S} / \mathrm{cm}$ throughout the study period, flowed into this reach of the river.

The seepage run on the Big River downstream from the Leadwood Public Access (site $\mathrm{H}$ ) to site 6 was completed November 6-8, 1989 (fig. 16). To maintain consistency with the previous seepage run, the discharge was remeasured at site $A$ and site $H$. Base flow was larger at site $A\left(31 \mathrm{ft}^{3} / \mathrm{s}\right)$ as compared with the previous value $\left(22 \mathrm{ft}^{3} / \mathrm{s}\right)$, probably because of rainfall in October and decreased evapotranspiration caused by frost in October and November. Specific conductance values in the Big River increased from $499 \mu \mathrm{S} / \mathrm{cm}$ at site $\mathrm{H}$ to $642 \mu \mathrm{S} / \mathrm{cm}$ at site 6 , an increase of almost 30 percent. Specific conductance values from seeps and tributaries along this reach of the river were larger than values measured in the river and ranged from 879 to $2,440 \mu \mathrm{S} / \mathrm{cm}$. The specific conductance from a tributary just downstream from site $\mathrm{H}$ was $1,350 \mu \mathrm{S} / \mathrm{cm}$. Flow in the tributary mainly consisted of effluent from the Leadwood Sewage Treatment Plant. Discharge in the Big River increased about 10 percent from $36 \mathrm{ft}^{3} / \mathrm{s}$ at site $\mathrm{H}$ to $39 \mathrm{ft}^{3} / \mathrm{s}$ at site 3 . Nearly all of the increase in discharge $\left(2.5 \mathrm{ft}^{3} / \mathrm{s}\right)$ was contributed by tributaries and seeps measured along this reach of the river. Discharge at site 4 had a specific conductance value of $929 \mu \mathrm{S} / \mathrm{cm}$. Owl Creek, which drains the area south and south west of the Desloge tailings pile, had a specific conductance of $1,150 \mu \mathrm{S} / \mathrm{cm}$. In the bend of the Big River just downstream from site 3 that encompasses the Desloge tailings pile, discharge increased about 10 percent from 39 to $44 \mathrm{ft}^{3} / \mathrm{s}$. No flow was detected in any tributaries along this reach of the river. However, several flowing drill holes were observed within the stream channel 0.25 river mi downstream from site 3 . Specific conductance values increased slightly near the Desloge tailings pile from $622 \mu \mathrm{S} / \mathrm{cm}$ at site 3 to $640 \mu \mathrm{S} / \mathrm{cm}$ at site J. No substantial differences in flow were detected from the east side of the Desloge tailings pile (site J) to site 6 . A seep at a quarry upstream from site 6 had the largest specific conductance $(2,440 \mu \mathrm{S} / \mathrm{cm})$ measured during the seepage run on the Big River.

\section{Mass Balance of Selected Constituents}

To verify that the source for additional flow not accounted for by the measured inflows and the quality of this inflow into the Big River is from mine water, a mass balance of selected constituents was performed using data collected during the seepage runs on the Big River. By using two known 
discharges from an upstream and a downstream site and the known constituent concentrations from the upstream site, constituent concentrations can be estimated for the downstream site based on the increases in discharge and average constituent concentrations in inflow from abandoned mines. The constituent concentrations at the downstream site can be estimated using the equation below. The estimated concentrations can then be compared with the measured concentrations detected at the downstream site to determine if the assumption was correct.

$$
C_{2}=\frac{Q_{1}\left(C_{1}\right)+\left(Q_{2}-Q_{1}\right)(C m)}{Q_{2}},
$$

where $\mathrm{C}_{2}$ is the estimated constituent value or concentration, in microsiemens per centimeter, milligrams per liter, or micrograms per liter, at the downstream site;

$\mathrm{Q}_{1}$ is the discharge at the upstream site, in cubic feet per second;

$\mathrm{C}_{1}$ is the constituent value or concentration, in microsiemens per centimeter, milligrams per liter, or micrograms per liter, at the upstream site;

$\mathrm{Q}_{2}$ is the discharge at the downstream site, in cubic feet per second; and

$\mathrm{Cm}$ is the assumed constituent concentration of mine water, in milligrams per liter or micrograms per liter, using median concentrations from quarterly samples from site 4 .

The results of mass-balance calculations at selected sites on the Big River are given in table 5 . Data from the September 1989 seepage run were used for calculations from site E to site H, and data from the November 1989 seepage run were used for all other calculations. All available specific conductance data from the seepage runs were used for conductance calculations for site $\mathrm{E}$ to site $\mathrm{H}$, for site $\mathrm{H}$ to site 3 , and for site $J$ to site 6 (figs. 14 and 16). Water-quality data were available for calculations involving constituent concentrations only at sites $\mathrm{E}, \mathrm{H}, 3, \mathrm{~J}$, and 6 . As previously stated, discharge measurements were considered to be accurate within plus or minus 5 percent. When these discharges are used in computations with analytical results, which also have associated measurement errors, the computed values probably are accurate within no more than plus or minus 10 percent.

Estimated specific conductance values were within 5 percent of the measured values for all stream reaches. Specific conductance values of additional inflow from seeps and tributaries into the Big River account for the increase in specific conductance values detected throughout the measured reach of the Big River.

The concentrations of major constituents estimated using equation 3 generally were in good agreement with measured concentrations. The estimated calcium and magnesium concentrations were within 10 percent of the measured concentrations for all stream reaches except for the reach from site $\mathrm{H}$ to site 3 . Estimated sodium concentrations were within 15 percent and estimated sulfate concentrations were within 20 percent of the measured concentrations for all stream reaches except for the reach from site $\mathrm{H}$ to site 3 . Other sources of inflow to the Big River may exist that were not detected or measured, such as effluent from a sewage treatment plant. Differences in calcium, magnesium, sodium, and sulfate concentrations also may exist between the mine sources. Estimated values for calcium, magnesium, and sulfate for the reach from site $\mathrm{H}$ to site 3 had the largest variation from the measured values for all the reaches and were always less than the measured values. 
Table 5.--Mass-balance analysis of selected properties and constituents in the Big River

$[\mu \mathrm{S} / \mathrm{cm}$, microsiemens per centimeter at 25 degrees Celsius; $\mathrm{mg} / \mathrm{L}$, milligrams per liter; $\mu \mathrm{g} / \mathrm{L}$, micrograms per liter; first number is property or constituent value or concentration measured during seepage run (September 13,1989, or November 6-8, 1989); second number is value or concentration of property or constituent estimated using a mass-balance equation; number in parentheses is percentage difference between the estimated and the measured value or concentration]

\begin{tabular}{cllllll}
\hline $\begin{array}{c}\text { Site letter } \\
\text { or number } \\
\text { (figs. 14 and 16) }\end{array}$ & $\begin{array}{c}\text { Specific } \\
\text { conductance } \\
(\mu \mathrm{S} / \mathrm{cm})\end{array}$ & $\begin{array}{c}\text { Calcium } \\
(\mathrm{mg} / \mathrm{L})\end{array}$ & $\begin{array}{c}\text { Magnesium } \\
(\mathrm{mg} / \mathrm{L})\end{array}$ & $\begin{array}{c}\text { Sodium } \\
(\mathrm{mg} / \mathrm{L})\end{array}$ & $\begin{array}{c}\text { Sulfate } \\
(\mathrm{mg} / \mathrm{L})\end{array}$ & $\begin{array}{c}\text { Zinc } \\
(\mu \mathrm{g} / \mathrm{L})\end{array}$ \\
\hline E to H & $535,558(4)$ & $58,57(-2)$ & $36,36(0)$ & $5.0,5.1(2)$ & $71,83(17)$ & $31,77(148)$ \\
H to 3 & $622,594(-5)$ & $64,54(-16)$ & $40,34(-15)$ & $5.9,4.7(-20)$ & $93,67(-27)$ & $100,103(3)$ \\
3 to J & $640,656(2)$ & $65,69(6)$ & $40,36(-10)$ & $5.5,6.3(15)$ & $100,110(10)$ & $150,111(-26)$ \\
J to 6 & $642,652(0.02)$ & $70,66(-6)$ & $40,40(0)$ & $6.2,5.6(-10)$ & $100,103(3)$ & $91,151(66)$ \\
\hline
\end{tabular}

The only zinc concentration that was estimated within 10 percent was in the reach from site $\mathrm{H}$ to site 3. For this reach, there was a 3 percent difference between the estimated and the measured concentrations. In the rest of the stream reaches, the estimated concentrations of zinc were substantially different from the measured concentrations. From site E to site $\mathrm{H}$, the estimated concentration was 148 percent larger than the measured concentration. Similarly, the zinc concentration for the reach from site $J$ to site 6 was estimated 66 percent larger than the measured concentration. The estimated zinc concentration from site 3 to site $\mathrm{J}$ was about 25 percent less than the measured concentration.

\section{SEDIMENT QUALITY}

Suspended-sediment and bed-sediment samples were collected at sampling sites throughout the Old Lead Belt (fig. 5). Results of analyses of these sediment samples are given in a report by Smith and Schumacher (1991).

\section{Suspended Sediment}

Suspended-sediment concentrations were determined at sites 1, 2, 3, 6, 7, 9, 10, 11, and 12 . Concentrations at all sites, excluding site 10 , were less than $35 \mathrm{mg} / \mathrm{L}$ (fig. 17). Site 10 has a large variation in suspended-sediment concentration because of difficulty in collecting a representative sample due to the small size and steep gradient of the channel and turbulent flow. The largest suspended-sediment concentration of $95 \mathrm{mg} / \mathrm{L}$ at site 10 was in a sample collected shortly after 1.5 in. of rainfall (Bryant Aubuchon, St. Francois County Landfill, written commun., 1990). Median suspended-sediment concentrations during periods of base flow did not increase substantially within the mining area in either the Big River or the Flat River. 


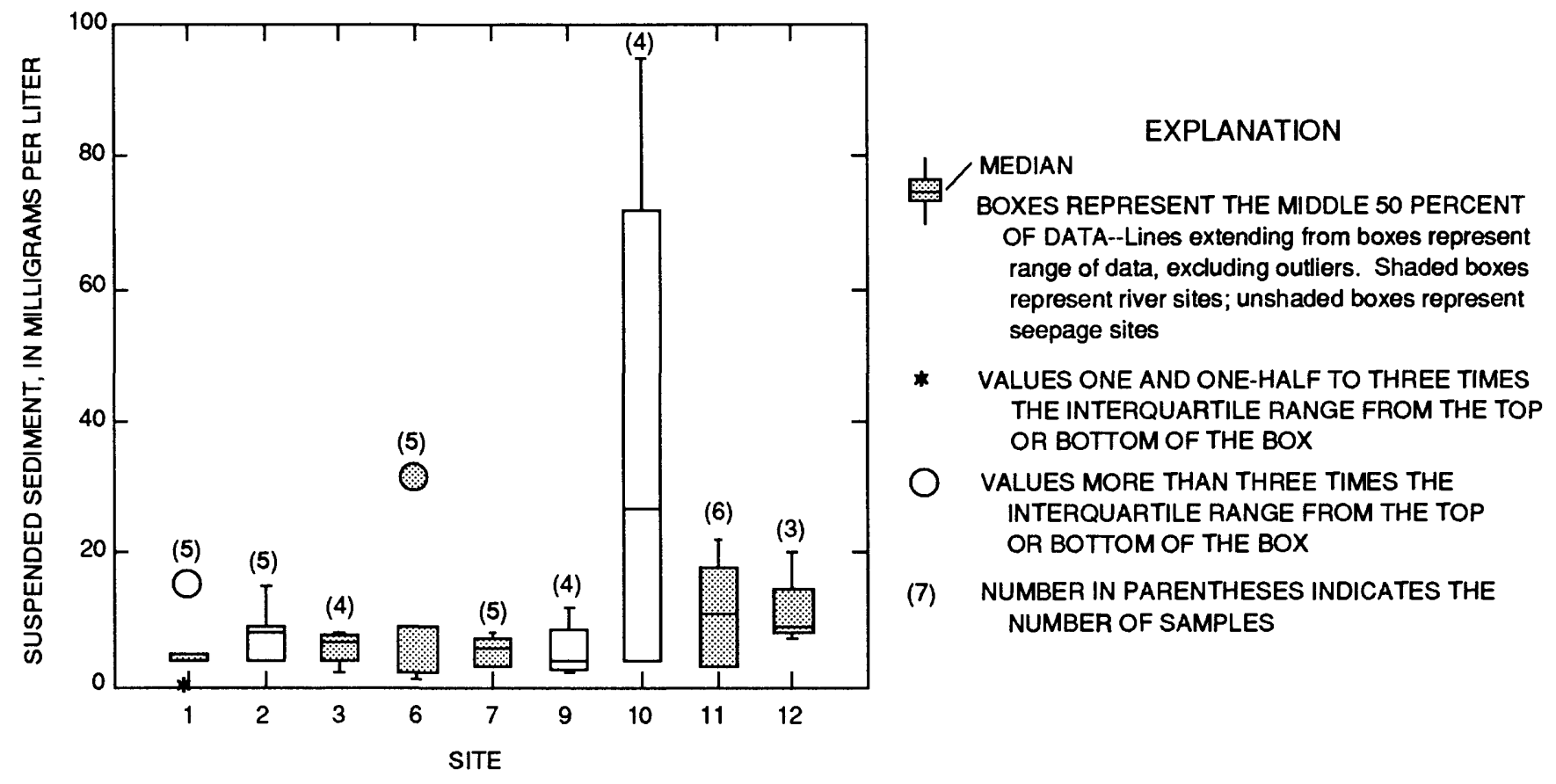

Figure 17.--Distribution of suspended-sediment concentrations.

\section{Particle-Size Distribution and Chemical Composition of Suspended Sediment During Periods of High Flow}

Suspended-sediment samples collected at sites 6 and 11 were analyzed for particle-size distribution. Results of analyses of these samples indicated that silt-size particles accounted for about 50 to 75 percent of suspended sediment during high flow. Clay-size particles generally accounted for about 25 to 33 percent of the suspended sediment, and sand-size particles generally accounted for less than 20 percent.

Concentrations of selected constituents in suspended-sediment samples collected during periods of high flow are given in table 6. At site 6, suspended sediment contained 2.7 to 8.7 percent calcium and had concentrations of barium ranging from 390 to $630 \mu \mathrm{g} / \mathrm{g}$ (micrograms per gram), lead ranging from 1,100 to $3,200 \mu \mathrm{g} / \mathrm{g}$, and zinc ranging from 1,100 to $2,200 \mu \mathrm{g} / \mathrm{g}$. Larger chromium and nickel concentrations were detected in suspended-sediment samples collected at smaller discharges than at larger discharges, whereas smaller lead concentrations were detected in samples from the smaller discharges. At site 11, calcium constituted from 11 to 14 percent of the suspended sediment and the sediment had concentrations of barium ranging from 190 to $330 \mu \mathrm{g} / \mathrm{g}$, lead ranging from 2,800 to $5,200 \mu \mathrm{g} / \mathrm{g}$, and zinc ranging from 410 to $680 \mu \mathrm{g} / \mathrm{g}$. At site 11 , two samples were collected a few hours apart on March 20, 1989. Of these two sediment samples, the sample representing the greatest discharge had the greatest concentrations of most constituents, except for copper, lead, nickel, and zinc. 


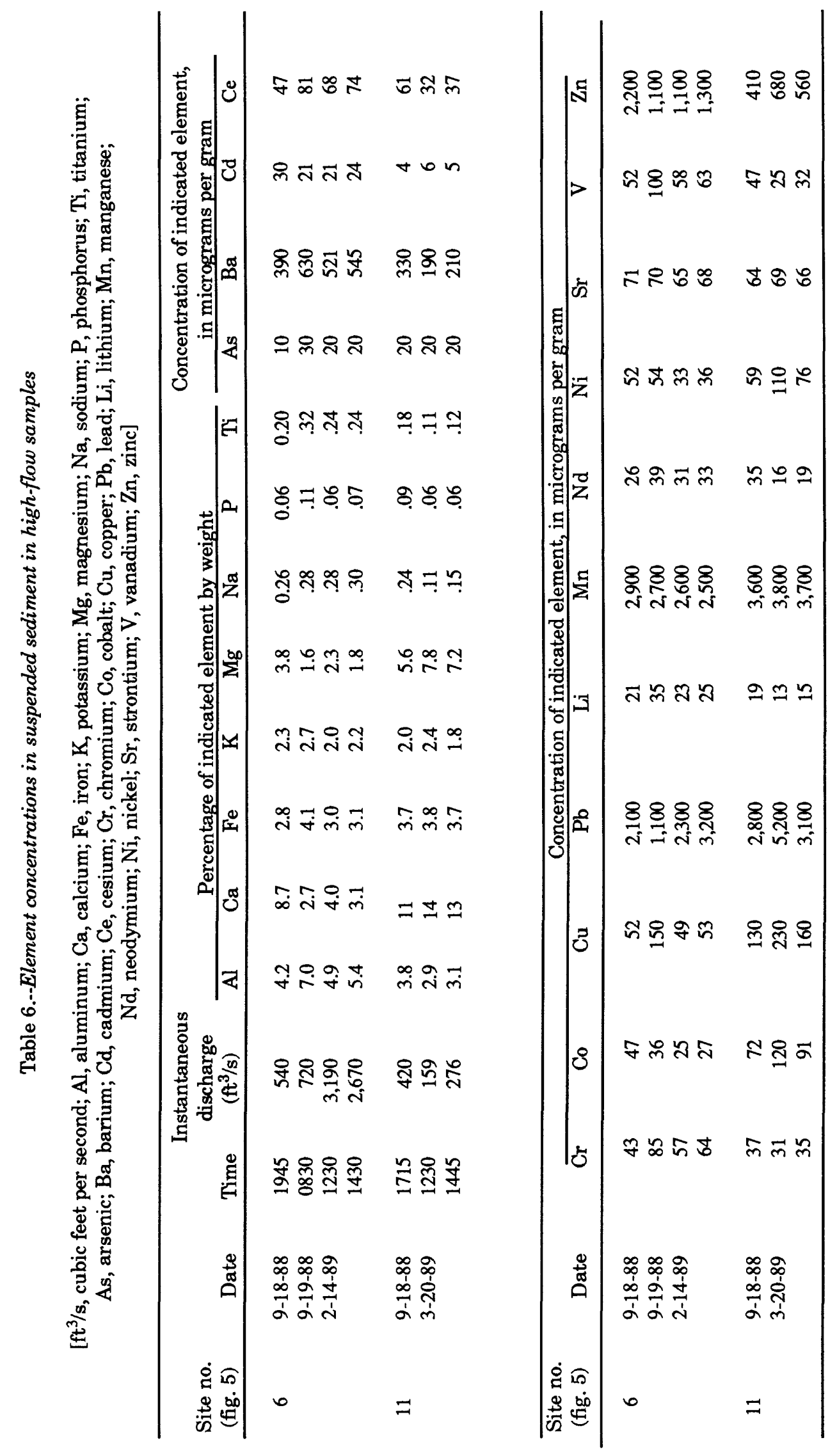




\section{Loads of Selected Trace Elements}

Schmitt and Finger (1982) used multiple regression analyses to investigate the relations between cadmium, copper, iron, lead, manganese, and zinc concentrations and particle size in suspended sediment in the Big River at Brown's Ford, which is less than 10 river mi downstream from site 12. Their models regressed total trace-element concentration in the suspended sediment with the percentage of sand-, silt-, and clay-size materials. These relations yielded large values of $r^{2}$ (between 0.97 and 0.99), indicating element concentrations were highly correlated with particle-size distribution. However, a large degree of auto-correlation might exist between regression coefficients, because one size class is a function of the remaining two classes. Data collected in this investigation indicate that, with the exception of zinc, concentrations of most trace elements were largest in the silt to clay size fraction.

The concentration of trace elements in the dissolved phase was much smaller than in the suspended phase; however, at low to intermediate flows, the small concentrations in the dissolved phase may be significant in a mass balance of dissolved and suspended phase transport because of the small quantities of suspended matter transported. To examine the relative importance of the dissolved and suspended phase transport in the Big River, estimates of the daily loads for barium, iron, lead, and zinc in both the dissolved and suspended phases were made at site 6. Instantaneous discharge measurements made at this site, in conjunction with the collection of quarterly water-quality and suspended-sediment samples, ranged from 36 to $257 \mathrm{ft}^{3} / \mathrm{s}$. The instantaneous discharge measurements closely approximate the daily mean discharge values for the date of sample collection. A plot of the daily mean discharge (fig. 18) indicates that the instantaneous discharge measurements (and associated water-quality and suspended-sediment measurements) made at the time of sample collection represents a range of discharges that encompasses about 80 percent of the daily mean discharges for the period of record. Regression analyses indicate that concentrations of several constituents, such as sulfate and barium, were highly correlated with instantaneous discharge $\left(r^{2}=0.87\right.$ and $\left.r^{2}=0.94\right)$. Because the instantaneous discharge values closely approximate the daily mean discharge for the date of sample collection, regression equations were used to estimate a daily mean constituent concentration from the daily mean discharge. These values were then multiplied by the daily mean discharge to estimate a daily mean constituent load, in tons per day. Estimates of daily mean loads for constituents not having a significant correlation with discharge were made by multiplying the median constituent concentration of the quarterly samples by the daily mean discharge for each day.

Relations between suspended-sediment concentrations and daily mean discharge also were examined by regression analyses. Instantaneous discharges at the time of collection of suspendedsediment samples were compared to the daily mean discharge hydrograph. Except for the 3 days on which high-flow samples were collected, the instantaneous discharge measured during sample collection approximated the daily mean discharge. Assuming the shape of the sediment hydrograph parallels the shape of the discharge hydrograph, although shifted slightly in time, daily mean concentrations of suspended sediment can be estimated from the discharge. A linear fit through a log-log plot of suspended-sediment concentration and daily mean discharge (fig. 19) was used to estimate daily mean suspended-sediment concentrations for each day of the period of record (554 days). The regression equation used was

$$
\log \mathrm{ss}=1.16 \log \mathrm{Q}-1.403 \text {, }
$$

where ss is the daily mean suspended-sediment concentration, in milligrams per liter, and $Q$ is the daily mean discharge, in cubic feet per second. This equation was used for values of discharge greater than $65 \mathrm{ft}^{3} / \mathrm{s}$. For discharges less than $65 \mathrm{ft}^{3} / \mathrm{s}$, instantaneous measurements indicated near uniform concentrations of suspended sediment and a concentration of $2 \mathrm{mg} / \mathrm{L}$ was assumed. Concentrations of suspended sediment were then used to calculate the load of suspended sediment, in tons per day. 


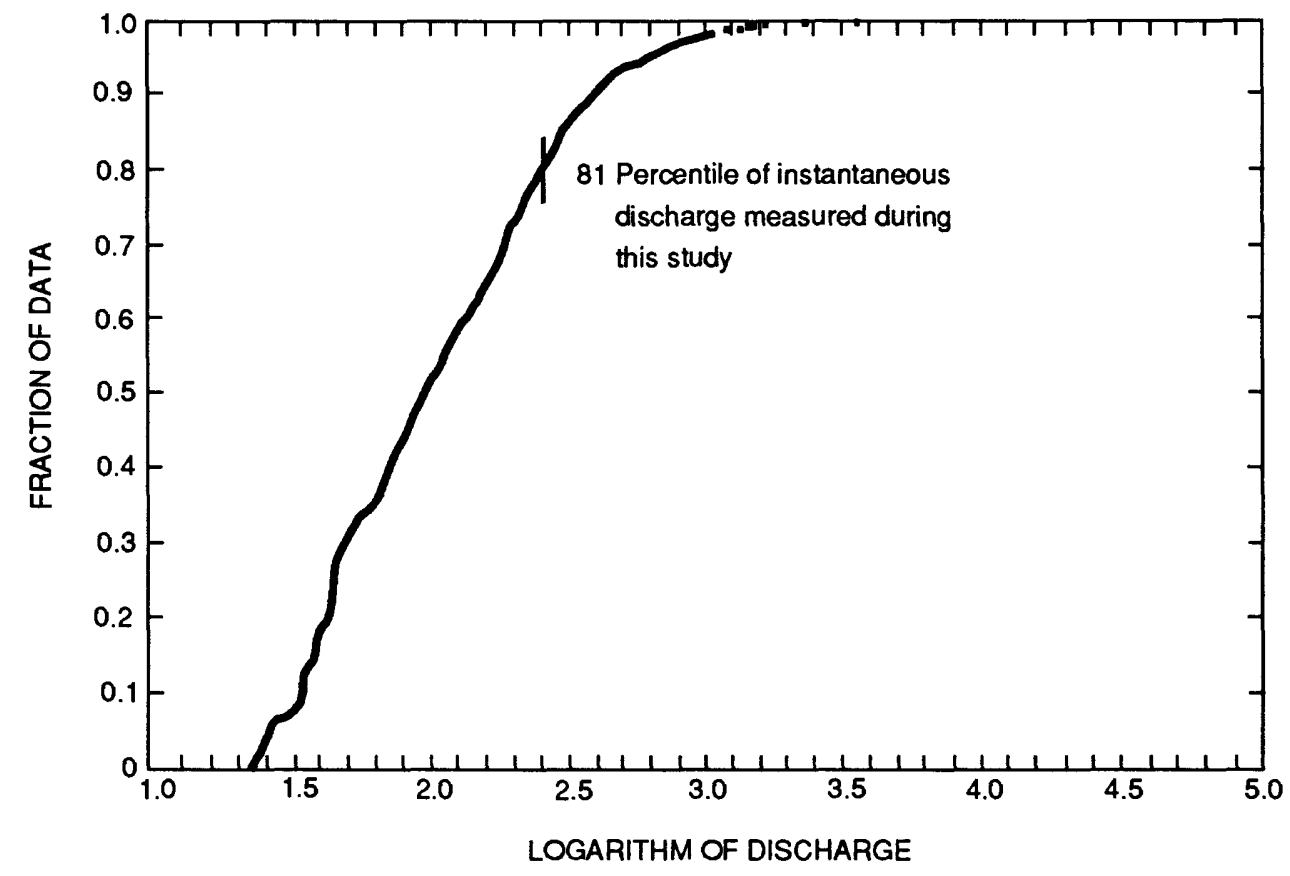

Figure 18.--Daily mean discharge values from March 1988 through September 1989 at site 6.

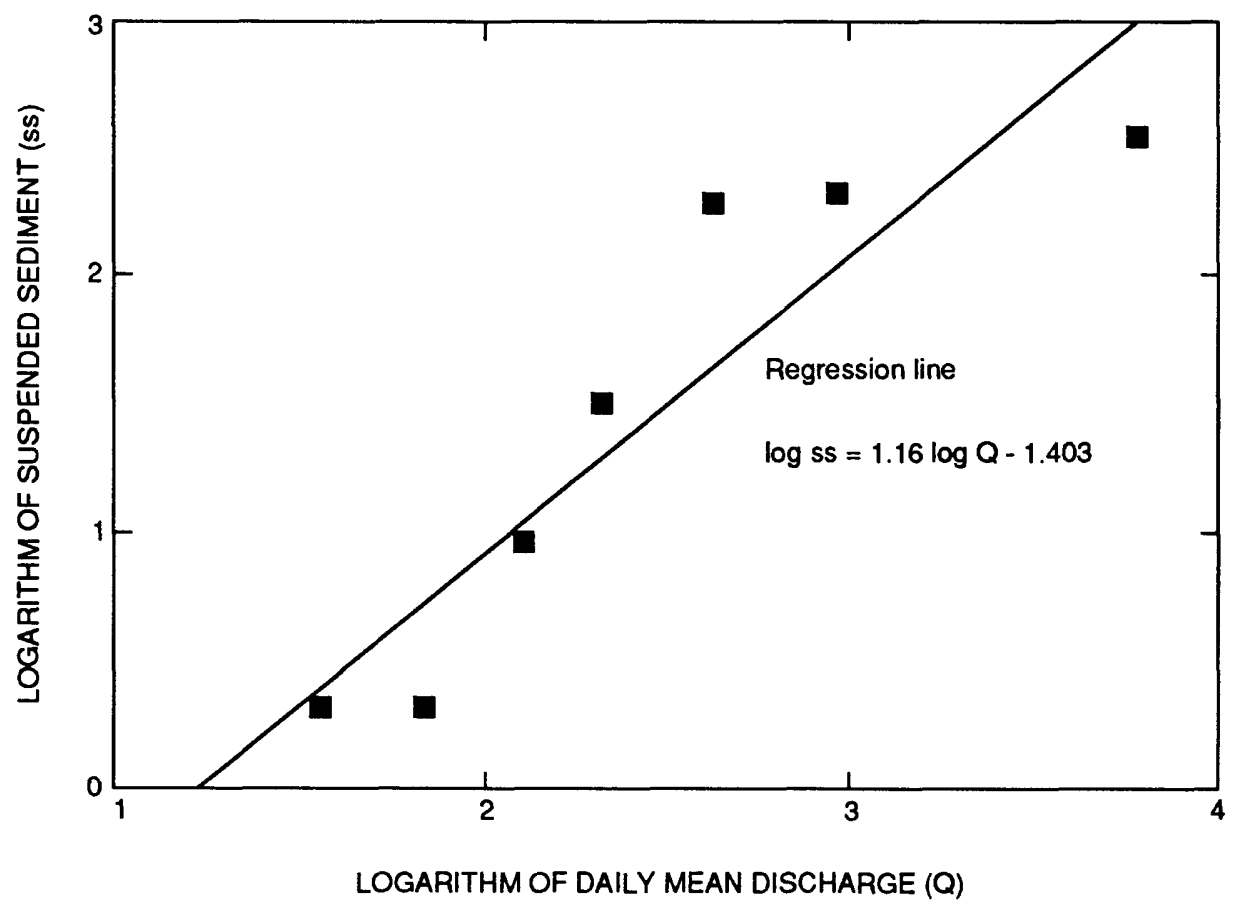

Figure 19.--Suspended-sediment concentration as a function of daily mean discharge at site 6. 
In addition to estimates of daily mean suspended-sediment loads, estimates of daily loads of barium, iron, lead, and zinc were calculated. The median concentration of these constituents in the four high-flow samples was used as an approximation for the concentration in the suspended sediment. These values were multiplied by the estimated daily mean suspended-sediment concentration to compute daily mean loads of each trace element.

Dissolved and suspended loads of barium, iron, lead, and zinc at low flows in the Big River are listed in table 7. The data in this table indicate that, even though suspended-sediment concentrations are small at low flows, more than 90 percent of the iron and lead probably is transported in the suspended phase at discharges less than $258 \mathrm{ft}^{3} / \mathrm{s}$. Dissolved transport seems to be more important for barium and zinc because 93 percent of the barium and 89 percent of the zinc are transported in the dissolved phase in this range of discharge. Calculations of total sediment loads for the period of record indicate individual high-flow events transport substantial quantities of sediment. Estimated total loads of suspended barium, iron, lead, zinc, and suspended sediment transported by the Big River during the period of record are listed in table 8 . The estimate for total suspended sediment transported during the 19 months of record (about 41,000 tons) is comparable to suspended sediment transported (about 66,000 tons) at a station on the St. Francis River, about 40 river mi south of the Old Lead Belt, operated by the U.S. Geological Survey during a 10-month period from December 1988 to September 1989 (Waite and others, 1990). The drainage area of the St. Francis River at Saco (664 $\left.\mathrm{mi}^{2}\right)$ is more than twice as large as that of the Big River below Desloge $\left(260 \mathrm{mi}^{2}\right)$. A single high-flow event at site 6 on the Big River (February 13-15, 1989) transported about 17,000 tons or about 40 percent of the total suspended sediment for the period of record. This event also transported substantial quantities of trace elements in the solid phase; about 20 tons of barium, 1,200 tons of iron, 90 tons of lead, and 50 tons of zinc.

Although these calculations are at best approximations and errors of as much as 50 percent are not unlikely, the effects of lead mining activities in the Big River upstream from Desloge are most readily observed in the quantities of dissolved barium and zinc and suspended lead and iron transported by the river. These calculations also indicate that an individual high-flow event can transport substantial quantities of sediment and associated trace elements. More accurate determinations of dissolved and suspended transport of trace elements would require additional data collection targeted specifically at high-flow events.

Table 7.--Dissolved and suspended loads for selected trace elements in the Big River at site 6 at low flow

[All values are in tons per day; flows are less than 258 cubic feet per second]

\begin{tabular}{|c|c|c|c|c|c|}
\hline \multirow[b]{2}{*}{ Constituent } & \multicolumn{3}{|c|}{ Load } & \multirow{2}{*}{$\begin{array}{l}\text { Percent } \\
\text { dissolved }\end{array}$} & \multirow{2}{*}{$\begin{array}{c}\text { Percent } \\
\text { suspended }\end{array}$} \\
\hline & Dissolved & Suspended & Total & & \\
\hline Barium & 9.4 & 0.73 & 10.1 & 93 & 7 \\
\hline Iron & .67 & 42 & 42.7 & 2 & 98 \\
\hline Lead & .22 & 3.0 & 3.2 & 7 & 93 \\
\hline Zinc & 13 & 1.6 & 14.6 & 89 & 11 \\
\hline
\end{tabular}


Table 8.--Total loads of barium, iron, lead, zinc, and suspended sediment transported by the Big River at site 6 for February 13-15, 1989, and for the period of record, March 1988 through September 1989

[All values are in tons; period of record is 554 days]

\begin{tabular}{lcr}
\hline \multirow{2}{*}{ Constituent } & \multicolumn{2}{c}{ Total load } \\
\cline { 2 - 3 } & February $13-15,1989$ & Period of record \\
\hline Barium & 9 & 22 \\
Iron & 500 & 1,200 \\
Lead & 40 & 90 \\
Zinc & 20 & 49 \\
Suspended sediment & 17,000 & 41,000 \\
\hline
\end{tabular}

\section{Bed Sediment}

A discussion of bed-sediment data is presented in the following sections. This discussion includes results of previous investigations, the particle-size distribution, mineralogy, and chemical composition of samples collected during this investigation.

\section{Previous Investigations}

In the Big River upstream from the Old Lead Belt, Zachritz (1978) reported background lead concentrations in bed sediment that ranged from 50 to $100 \mu \mathrm{g} / \mathrm{g}$, zinc concentrations that ranged from 55 to $340 \mu \mathrm{g} / \mathrm{g}$, cadmium concentrations that ranged from 1 to $5 \mu \mathrm{g} / \mathrm{g}$, and copper concentrations that ranged from 12 to $15 \mu \mathrm{g} / \mathrm{g}$. Within the Old Lead Belt, lead concentrations in bed sediment ranged from 673 to $8,150 \mu \mathrm{g} / \mathrm{g}$, zinc concentrations ranged from 1,025 to $8,558 \mu \mathrm{g} / \mathrm{g}$, cadmium concentrations ranged from 11 to $180 \mu \mathrm{g} / \mathrm{g}$, and copper concentrations ranged from 35 to $360 \mu \mathrm{g} / \mathrm{g}$. Increased trace-element concentrations in bed sediment were detected for about 60 river mi downstream from the Old Lead Belt (Zachritz, 1978).

Kramer (1976) reported that lead concentrations in bed sediment of the Flat River downstream from the Elvins tailings pile and the Federal tailings pile ranged from 2,050 to $3,140 \mu \mathrm{g} / \mathrm{g}$, zinc concentrations ranged from 322 to $7,450 \mu \mathrm{g} / \mathrm{g}$, cadmium concentrations ranged from 7 to $24 \mu \mathrm{g} / \mathrm{g}$, and copper concentrations ranged from 54 to $181 \mu \mathrm{g} / \mathrm{g}$. Bed sediment from the seepage channel at the Elvins tailings pile had a lead concentration of $3,900 \mu \mathrm{g} / \mathrm{g}$, a zinc concentration of $36,200 \mu \mathrm{g} / \mathrm{g}$, a cadmium concentration of $35 \mu \mathrm{g} / \mathrm{g}$, and a copper concentration of $96 \mu \mathrm{g} / \mathrm{g}$. Bed sediment from two seepage channels at the Federal tailings pile had lead concentrations of 3,360 and $3,420 \mu \mathrm{g} / \mathrm{g}$, zinc concentrations of 441 and $1,960 \mu \mathrm{g} / \mathrm{g}$, cadmium concentrations of 10 and $13 \mu \mathrm{g} / \mathrm{g}$, and copper concentrations of 154 and $161 \mu \mathrm{g} / \mathrm{g}$ (Kramer, 1976).

Bed-sediment samples collected from the Flat River upstream from the National tailings pile (Elliot, 1982) had a maximum lead concentration of $10,123 \mu \mathrm{g} / \mathrm{g}$ and a maximum zinc concentration of $3,146 \mu \mathrm{g} / \mathrm{g}$. Runoff from the Elvins and the Federal tailings piles probably was the cause of the large quantities of trace elements detected. Bed sediment in the Flat River and the Big River downstream from the National tailings pile had lead concentrations that ranged from 1,013 to $7,221 \mu \mathrm{g} / \mathrm{g}$. Zinc concentrations ranged from 115 to $4,875 \mu \mathrm{g} / \mathrm{g}$, cadmium concentrations ranged from 5 to $889 \mu \mathrm{g} / \mathrm{g}$, and copper concentrations ranged from 56 to $332 \mu \mathrm{g} / \mathrm{g}$. As the quantity of tailings in the streambed 
decreased downstream from the tailings pile, the concentration of trace elements increased in the bed sediment. The concentration of trace elements also increased with a decrease in particle size (Elliott, 1982).

The lead concentration in tailings from the Desloge tailings pile as reported by Novak and Hasselwander (1980) ranged from 850 to $2,400 \mu \mathrm{g} / \mathrm{g}$, the zinc concentration ranged from 680 to 1,000 $\mu \mathrm{g} / \mathrm{g}$, the cadmium concentration ranged from 14 to $25 \mu \mathrm{g} / \mathrm{g}$, and the copper concentration ranged from 11 to $41 \mu \mathrm{g} / \mathrm{g}$. The lead concentration in tailings from the Elvins tailings pile (Kramer, 1976) ranged from 2,360 to $26,200 \mu \mathrm{g} / \mathrm{g}$. The zinc concentration ranged from 288 to $20,900 \mu \mathrm{g} / \mathrm{g}$, the cadmium concentration ranged from 8 to $158 \mu \mathrm{g} / \mathrm{g}$, and the copper concentration ranged from 12 to $610 \mu \mathrm{g} / \mathrm{g}$. The largest concentration of trace elements was detected in the smallest size fraction (Kramer, 1976). The lead concentration in tailings from the National tailings pile (Elliot, 1982) ranged from 1,177 to $9,283 \mu \mathrm{g} / \mathrm{g}$. The zinc concentration ranged from 34 to $5,055 \mu \mathrm{g} / \mathrm{g}$ with most concentrations less than $1,000 \mu \mathrm{g} / \mathrm{g}$. The cadmium concentration ranged from 2 to $87 \mu \mathrm{g} / \mathrm{g}$, and the copper concentration ranged from 32 to $628 \mu \mathrm{g} / \mathrm{g}$ (Elliott, 1982). No data are available for the trace-element concentration of the Bonne Terre, Leadwood, and Federal tailings piles.

\section{Particle-Size Distribution}

Many of the tailings piles in the study area contain two kinds of tailings material: coarser tailings hauled to the site and finer tailings (slimes) pumped to the site as a slurry. Tailings samples collected from the slimes area of the Desloge tailings pile have been shown to contain 1.2 percent claysize particles [less than $0.002 \mathrm{~mm}$ (millimeter)], 85.7 percent silt-size particles (less than 0.062 to 0.002 $\mathrm{mm}$ ), and 13.1 percent sand-size particles (less than 2 to $0.062 \mathrm{~mm}$ ). Samples of the coarser tailings contained 2.2 percent clay-size particles, 15.9 percent silt-size particles, and 81.9 percent sand-size particles (S.J. Sutley, U.S. Geological Survey, written commun., 1990).

Sand was the predominant size fraction in streambed sediment at most sites in the study area (fig. 20). The percentage of sand-size particles varied from site to site, but generally was largest at seepage sites that were closely associated with a tailings pile (sites $5,8,9$, and 10). At these sites, sand-size particles constituted from 60 to more than 90 percent of the bed material. Even though site 2 was near a tailings pile, the percentage of sand-size particles at this site was not as large as at the other sites. At this site, the bottom of the seepage channel was not in tailings but in bedrock, where samples were difficult to obtain and the size distribution probably was not representative of bed sediment. Site 3 had the largest percentage of sand of the Big River sites.

Gravel-size particles ( $2 \mathrm{~mm}$ or larger) were predominant at site 1 (65 to 85 percent) and made up almost 50 percent of the bed sediment at site 7 on the Flat River. At sites on the Big River within the Old Lead Belt, gravel-size particles made up a much smaller percentage of the bed sediment. The percentage of gravel-size particles was largest at sites either upstream or downstream from the mining area in both the Big River and Flat River. At sites 1 and 12, the largest percentage of gravel-size particles was detected in the samples collected in September 1989. Because these two sampling sites were at bends in the river near riffle areas, this percentage could be a result of increased flow that had removed the smaller particles.

Silt- and clay-size particles constituted less than 15 percent of bed sediment at all sites. Sites 5 and 10 had the largest percentage of silt-size particles (fig. 20). Runoff and flow at these sites were through the slimes areas. Percentages of clay-size particles in bed sediment generally were less than 1 percent and were greatest at sites $2,5,6$, and 10 . 


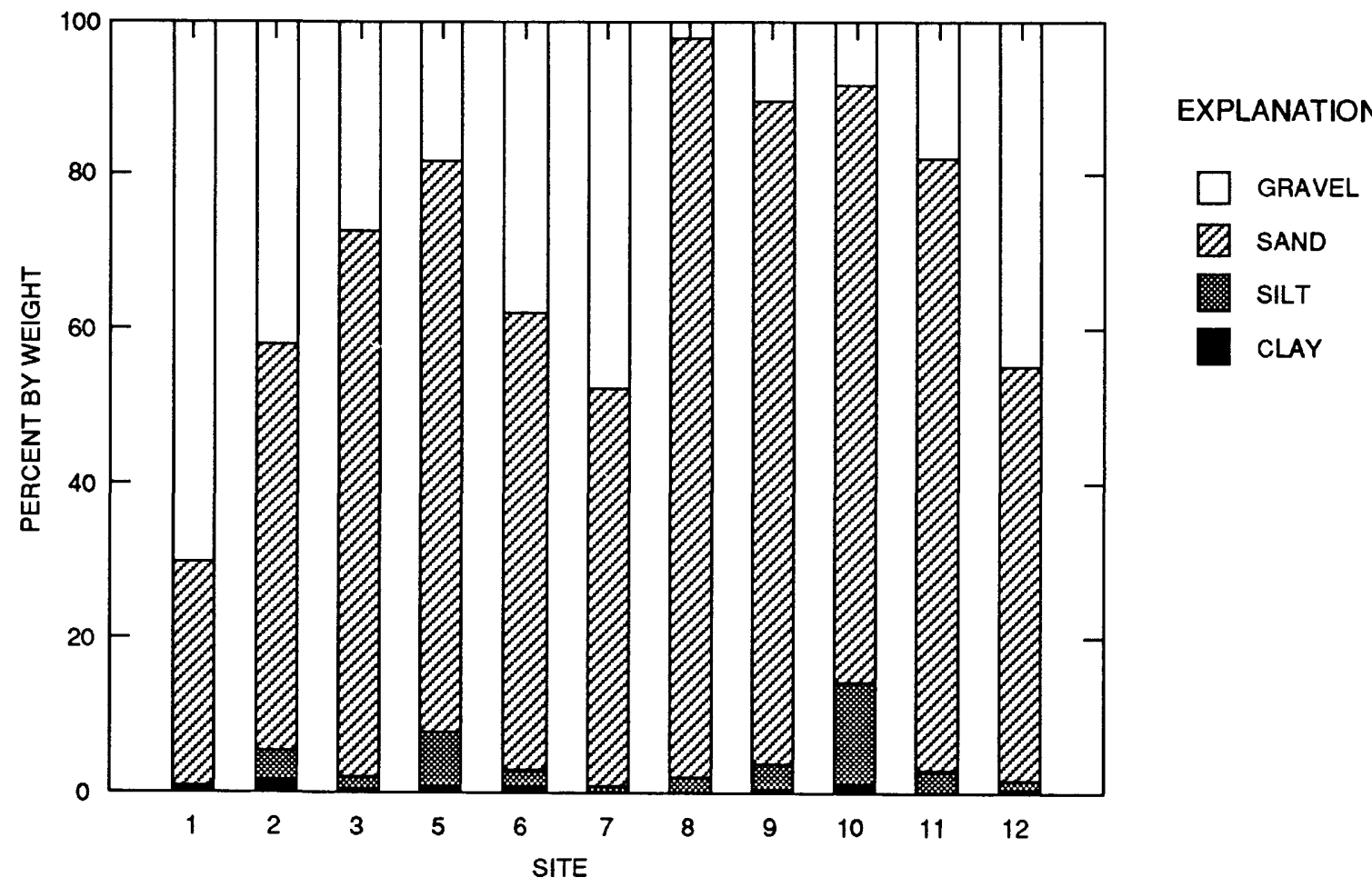

Figure 20.--Particle-size distribution of bed sediment.

The particle-size distribution of the bed sediment for the four Big River sites is shown in figure 21. At site 1, the histogram is skewed to the left, indicating an abundance of larger particles, characteristic of Ozark streams. At site 3, downstream from a low-water crossing, the particle-size distribution reflects the effect of mine tailings that have a moderate to large abundance of sand-size particles and a lack of particles less than $0.5 \mathrm{~mm}$. The particle-size distribution at site 6 also reflects the abundance of mine tailings. Visual inspection of the streambed at this site indicated the streambed was completely composed of tailings, which would tend to make the distribution more uniform. The particle-size distribution at site 12 was somewhat bi-modal, and it is probable that the large peak at the $0.5-\mathrm{mm}$ grain size represents silt-size particles from barite mining, in addition to those from lead and zinc mining.

\section{Mineralogy}

Mineralogical analyses of bed-sediment samples collected during this investigation were made on the bulk sample, which was less than $180 \mu \mathrm{m}$ (micrometers), using X-ray diffraction techniques. For a detailed presentation of the analytical results, the reader is referred to Smith and Schumacher (1991). Mineralogy of bed sediment at river sites 1 and 12 was predominately quartz (at least 85 percent; fig. 22) and potassium feldspar. The bed sediment of site 1 was composed of quartz (90 to 95 percent) and minor quantities of dolomite. At site 12, the distribution of quartz and dolomite was not significantly different from that at site 1 because of the small effect of lead and zinc tailings or the large influx of quartz-rich sediment from Mineral Fork. At the upstream site on the Flat River (site 7), quartz constituted from 65 to 70 percent of the bed sediment, and potassium feldspar constituted a larger percentage of the bed sediment than at sites 1 and 12. The large quantity of potassium feldspar in bed sediment at this site probably is related to outcrops of Precambrian granite rocks of the St. Francois Mountains and Cambrian Lamotte Sandstone, which has a basal arkosic conglomerate.

Mineralogy of the bed sediment at the remaining sites (river sites 3,6 , and 11, and seepage sites $2,5,8,9$, and 10 ) was predominately carbonate, specifically dolomite and ankerite (iron-rich dolomite; fig. 22). The tailings predominately are dolomite because lead was mined from the Bonneterre Dolomite. At these sites where the mineralogy was predominately carbonate, dolomite and 


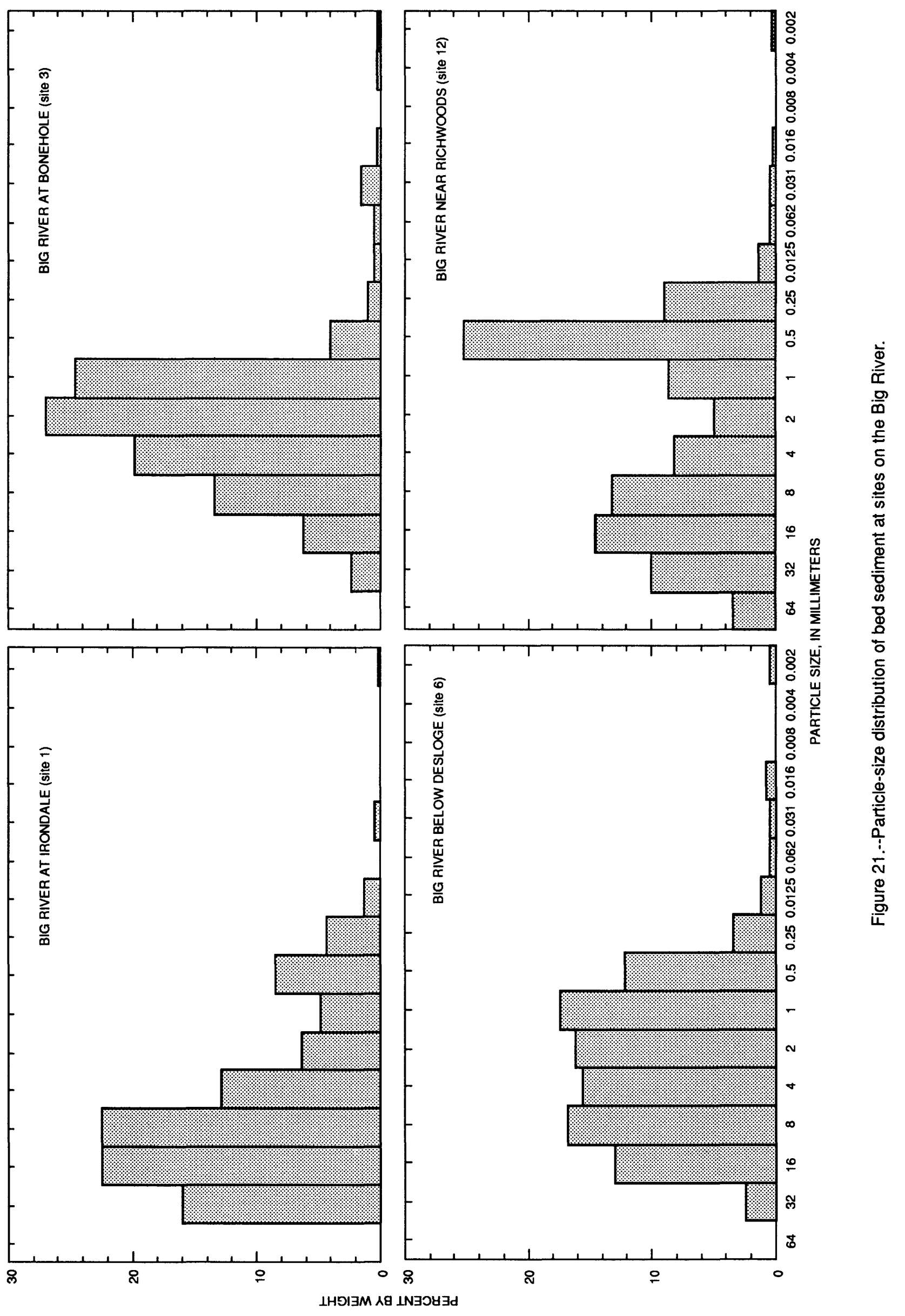



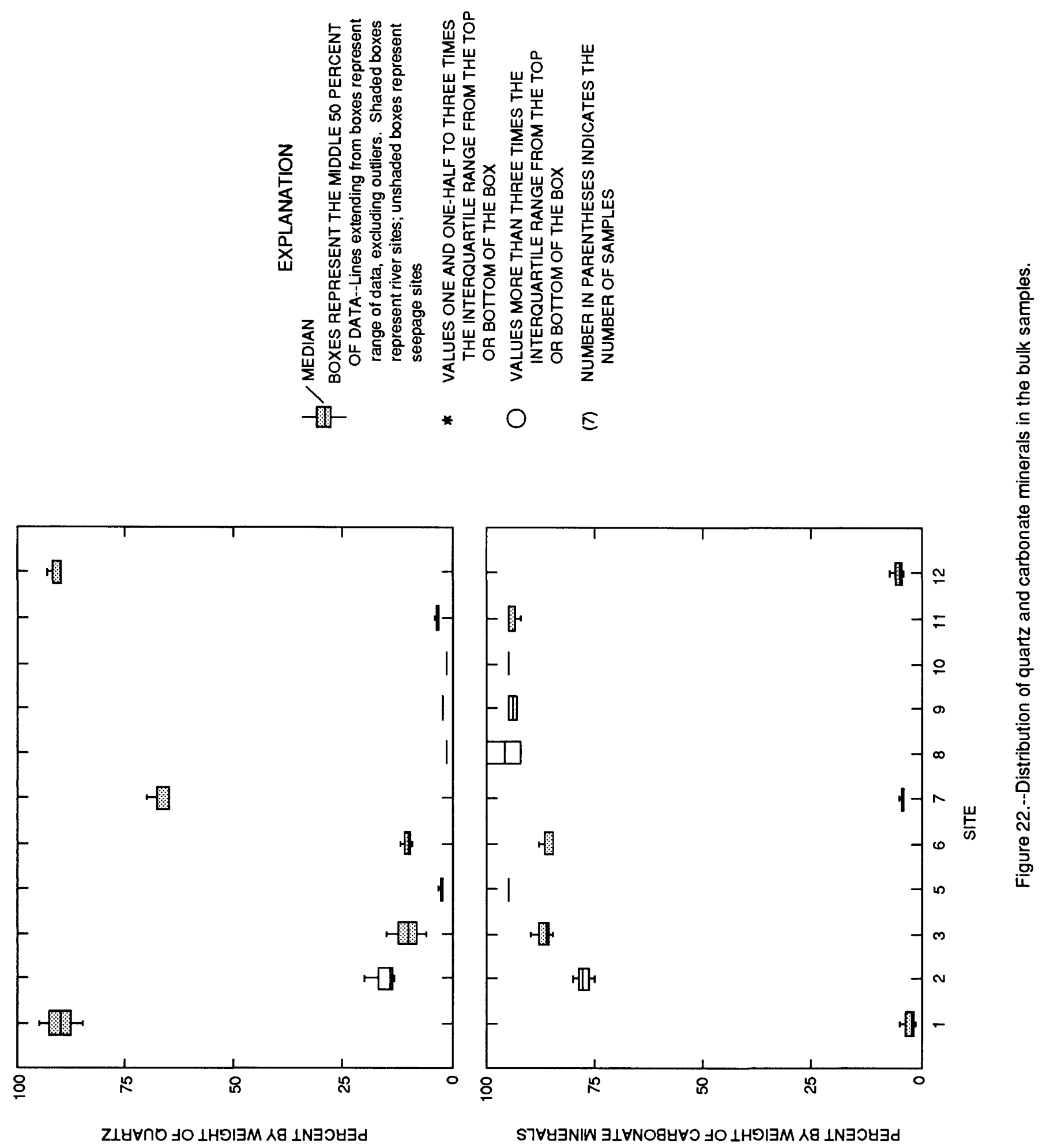
ankerite constituted at least 75 percent of the sample. At sites 3 and 6 on the Big River, the bed sediment was more than 90 percent dolomite and less than 5 percent quartz. Sites 2 and 5 had smaller ratios of quartz to dolomite, which is indicative of tailings, such as observed at seepage sites 8,9 , and 10. However, at site 2, quartz comprised from about 5 to 20 percent of the sample--a much larger percentage of the sample than at the other sites. If calcite was present at any site, it was less than 5 percent of the sample. A regression of dolomite, ankerite, and calcite percentages with quartz percentages was significant $\left(r^{2}=0.97\right)$ at all sites. Within the mining area, several sites $(2,3,6,8,9$, and 10) had small quantities (less than 3 percent) of sulfide minerals (galena and sphalerite). Gypsum was detected only at site 10 , where it was about 2 percent of the sample. Gypsum is not an ore mineral but is a secondary product of the oxidation of minerals and the subsequent dissolution of calcite or dolomite.

To further determine the effects of tailings in the Old Lead Belt and to characterize the differences in the mineralogic composition of the bed sediment in the mined areas as compared with bed sediment from areas unaffected by mining, sulfide and other ore minerals were examined in the bulk sample. The bulk sample was floated through bromoform (specific gravity 2.85) where the light minerals were removed and the heavy minerals were concentrated. The heavy minerals were subsequently passed through an isodynamic magnetic separator to produce three heavy mineral fractions: C-1, C-2, and C-3, based on their magnetic properties. Results of the analyses for each fraction have been reported by Smith and Schumacher (1991) and are discussed only briefly in this section. The C-1 fraction contains highly magnetic minerals. Magnetite was the only mineral detected in this fraction. At all sites, the percentage by weight of the C-1 fraction was 6 percent or less, when compared with the remaining two fractions.

The C-2 fraction contains the para-magnetic, mostly non-ore minerals, many of which occur in non-mineralized areas. For all sites, the percentage by weight of this fraction ranged from 13 to 100 percent. The C-2 fraction was the largest fraction for all sites. Major constituents of the C-2 fraction were mostly iron-rich carbonate and highly oxidized minerals. At all river sites, except site 11, carbonate minerals and oxidized minerals were the major constituents of this fraction. At site 11, carbonate minerals were the predominant constituent. Iron-rich carbonate minerals were the major constituent (as much as 90 percent) of the C-2 fraction from the rest of the sites. Galena and pyrite were the sulfides most often detected in the C-2 fraction samples from all sites. Galena is not normally associated with the C-2 fraction, but, when concentrations of this mineral are large, it can be carried over into the para-magnetic fraction. Pyrite was present in quantities of as much as 10 percent of the C-2 fraction sample. Two samples contained hematite--one sample each from site 3 and site 7 . The sample from site 7 contained about 20 percent hematite in the C-2 fraction.

The C-3 fraction contains the non-magnetic ore and non-ore minerals. Only at site 3 did the percentages by weight of the C-3 fraction exceed 50 percent (62 and 83 percent for two samples). Carbonate and sulfide minerals were the major constituents of the C-3 fraction (table 9 and Smith and Schumacher, 1991). Carbonate minerals ranged from 10 to 90 percent of the C-3 fraction in all samples. Dolomite, ankerite, and calcite were the carbonate minerals detected. Dolomite and ankerite were detected in one-half of the samples from all sites and calcite in one-third of the samples. Zinc substitution in dolomite was detected in two-thirds of all samples and the presence of a zinc-rich carbonate was detected in one-third of all samples.

Grain size and bulk mineralogic data for bed sediment indicated that sites 3,6 , and 11 were strongly affected by tailings. However, the data for the upstream sites for both the Big River and the Flat River (sites 1 and 7) indicated no mining-related effects, and the presence of lead-zinc mining-related effects at site 12 tend to be overshadowed by the effects from barite mining. Sulfide minerals in the C-3 fraction ranged from 10 to 30 percent at site 1 to 30 to 70 percent at site 3,30 to 40 percent at site 6 , and 10 percent at site 12 (table 9 ). At the river sites, as much as 40 percent of the sulfide minerals in bed sediment was galena and as much as 50 percent was pyrite. In the Big River at sites 3 and 6 , from 40 to 60 percent of the sulfide minerals in bed sediment was sphalerite. The 


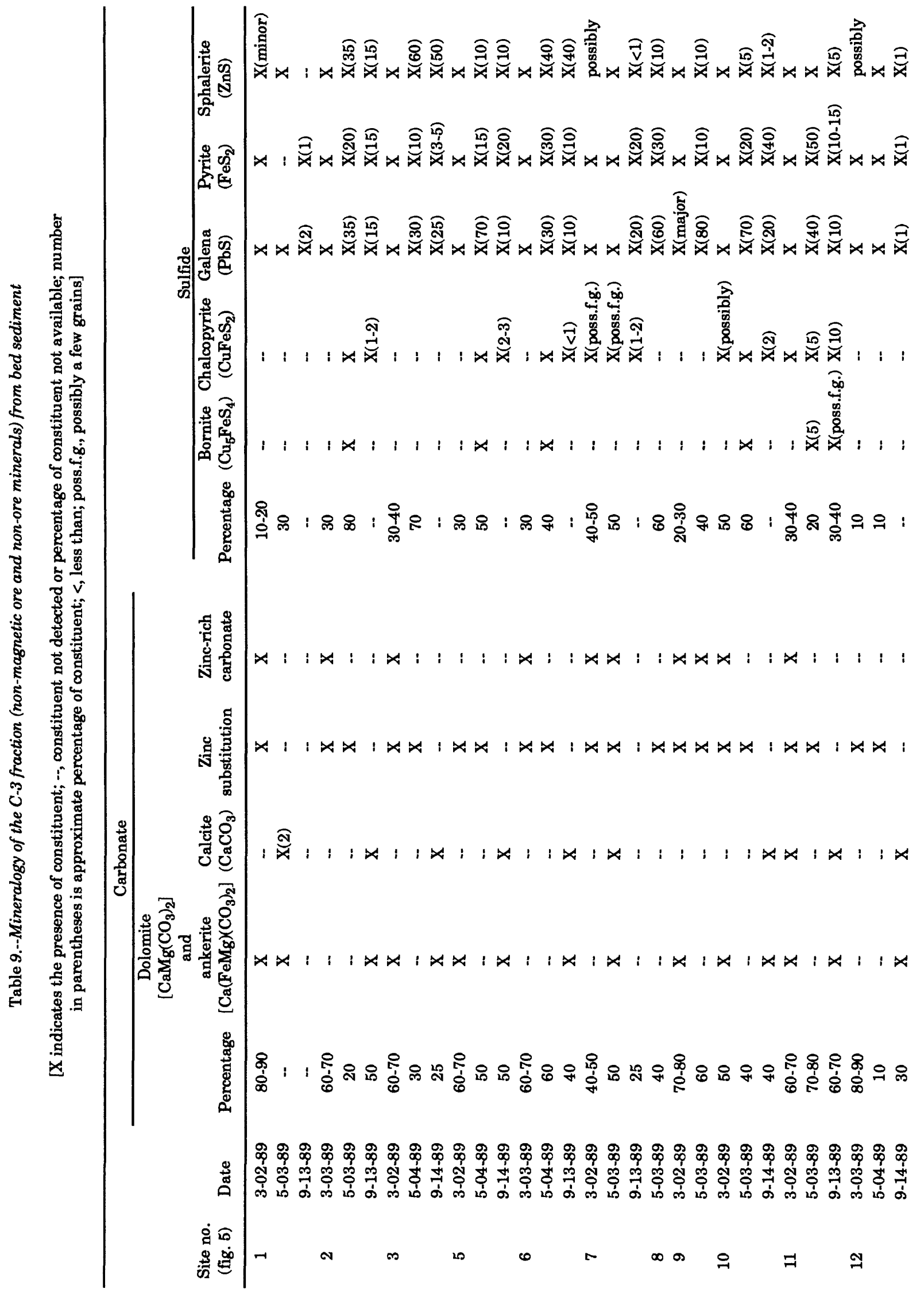




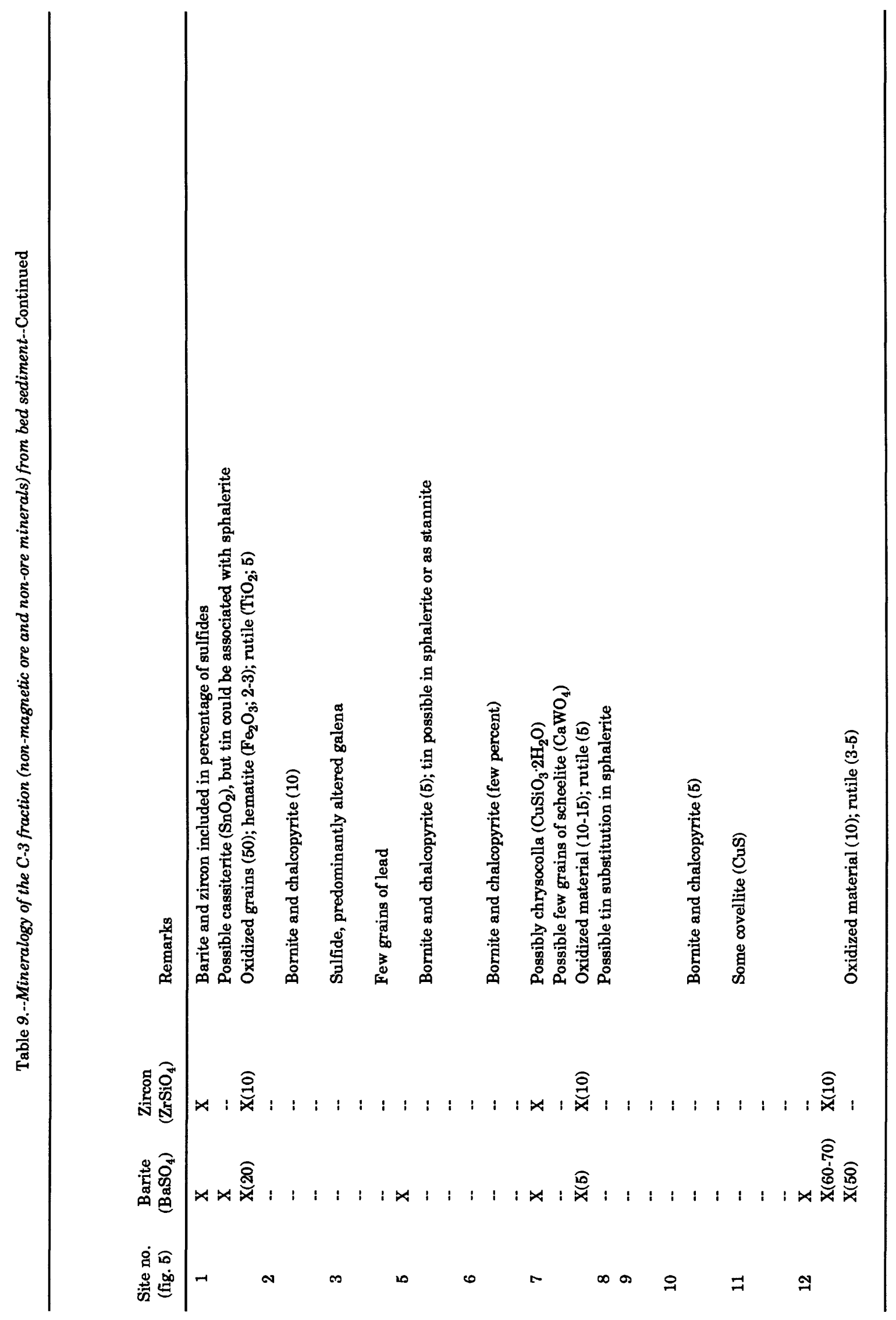


concentration of lead and zinc sulfides in non-magnetic minerals in the C-3 fraction increased from site 1 to sites 3 to 6 , but the concentration at site 12 was similar to that at site 1 . Effects of barite mining within the Mineral Fork basin are indicated by the barite concentration of the C-3 fraction of bed sediment increasing from about 20 percent at site 1 to about 50 to 70 percent at site 12 downstream from Mineral Fork.

Galena and sphalerite concentrations in bed sediment at site 3 generally equaled or exceeded that at site 6. The larger galena and sphalerite concentrations at site 3 could be caused by the low-water crossing trapping the denser minerals, such as sulfide minerals, within the sediment. Another less likely possibility is that the tailings derived from the Desloge pile have smaller quantities of lead and zinc sulfides than those from the Leadwood tailings pile.

In addition to the detailed mineralogic analyses, solid-phase associations were determined in the bed sediment using a scanning electron microscope equipped with energy dispersive and wavelength dispersive $x$-rays. At the upstream river sites (sites 1 and 7) and downstream site (site 12), most of the barium, iron, lead, manganese, titanium, and zinc were associated with the oxide phase. More iron in the oxide and sulfide phases was detected in the coarse fraction than in the fine fraction. At site 11, the quantity of iron in the sulfide phase decreased, but lead in the sulfide phase increased. As a result of mining activities, secondary minerals, such as lead sulfate, have formed within the tailings piles from the oxidation of tailings. At site 12, barium was detected in the phosphate and sulfate phases. The quantity of titanium in the oxide phase at site 2 was twice that in bed sediment from any other site. In bed-sediment samples collected at sites 8 and 9, zinc was detected in the carbonate phase in large quantities as compared to samples from other sites. Most of this was zinc carbonate coatings or rims around dolomite particles (fig. 23). Sorption and subsequent replacement of magnesium by zinc on dolomite particles may be an important mechanism controlling aqueous concentration of zinc. Some zinc also was present in the oxide phase. At site 10, relatively large quantities of iron were present, mostly in the sulfide phase, but also in the sulfate phase. Lead carbonate coatings were detected on calcite and dolomite particles (fig. 24) at this site.

\section{Chemical Composition}

Bed-sediment samples were analyzed for their chemical composition. Samples were divided into the fine fraction, less than $63 \mu \mathrm{m}$, and the coarse fraction, 63 to $180 \mu \mathrm{m}$. Results of these chemical analyses of these two size fractions are given in a report by Smith and Schumacher (1991) and are discussed briefly in this section.

The calcium and magnesium concentrations in bed sediment were largest in bed sediment collected within the mining area. The calcium concentrations in bed sediment in the Big River ranged from 0.70 to 13 percent in the fine fraction and 0.36 to 15 percent in the coarse fraction. The magnesium concentrations ranged from 0.42 to 6.6 percent in the fine fraction and 0.13 to 8.5 percent in the coarse fraction. Generally, the calcium and magnesium concentrations in the bed sediment of the Big River (fig. 25) increased from site 1 to site 3 and from site 3 to site 6 and decreased from site 6 to site 12. The calcium and magnesium concentrations in both size fractions of bed sediment from sites on the Flat River were nearly equal, but the calcium and magnesium concentrations increased substantially from site 7 to site 11 . The increase in calcium and magnesium concentrations at site 11 probably was caused by mine tailings from the Elvins and National tailings piles.

Barium concentrations in bed sediment in the Big River and the Flat River decreased downstream. Barium concentrations in bed sediment in the Big River at sites 3 and 6 were slightly smaller than those at the upstream site (site 1) and barium concentrations in the Flat River at site 11 were substantially smaller than those at the upstream site (site 7), indicating the tailings in the Old Lead Belt may actually contain smaller barium concentrations than the natural stream sediments. Semi-quantitative emission spectrographic analyses of sediments from the Desloge tailings pile indicated that barium concentrations were less than $300 \mu \mathrm{g} / \mathrm{g}$ (S.J. Sutley, written commun., 1990) as 


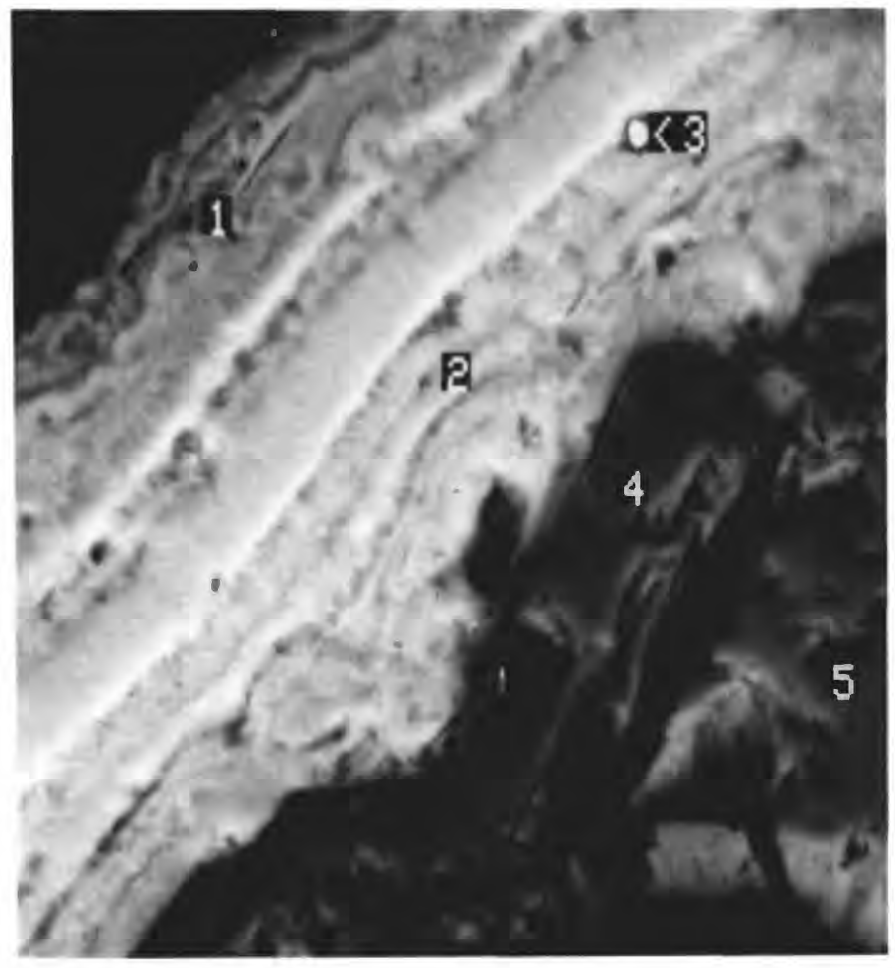

\section{EXPLANATION}

1 ZINC CARBONATE COATING DOLOMITE

2 ZINC CARBONATE

3 COBALT NICKEL SULFIDE

4 DOLOMITE

5 CALCIUM CARBONATE

EXPLANATION

1 ZINC CARBONATE

2 CALCIUM CARBONATE

3 DOLOMITE

Figure 23.--Scanning electron photomicrographs of bed sediment showing zinc carbonate coating dolomite particles from site 8 . 


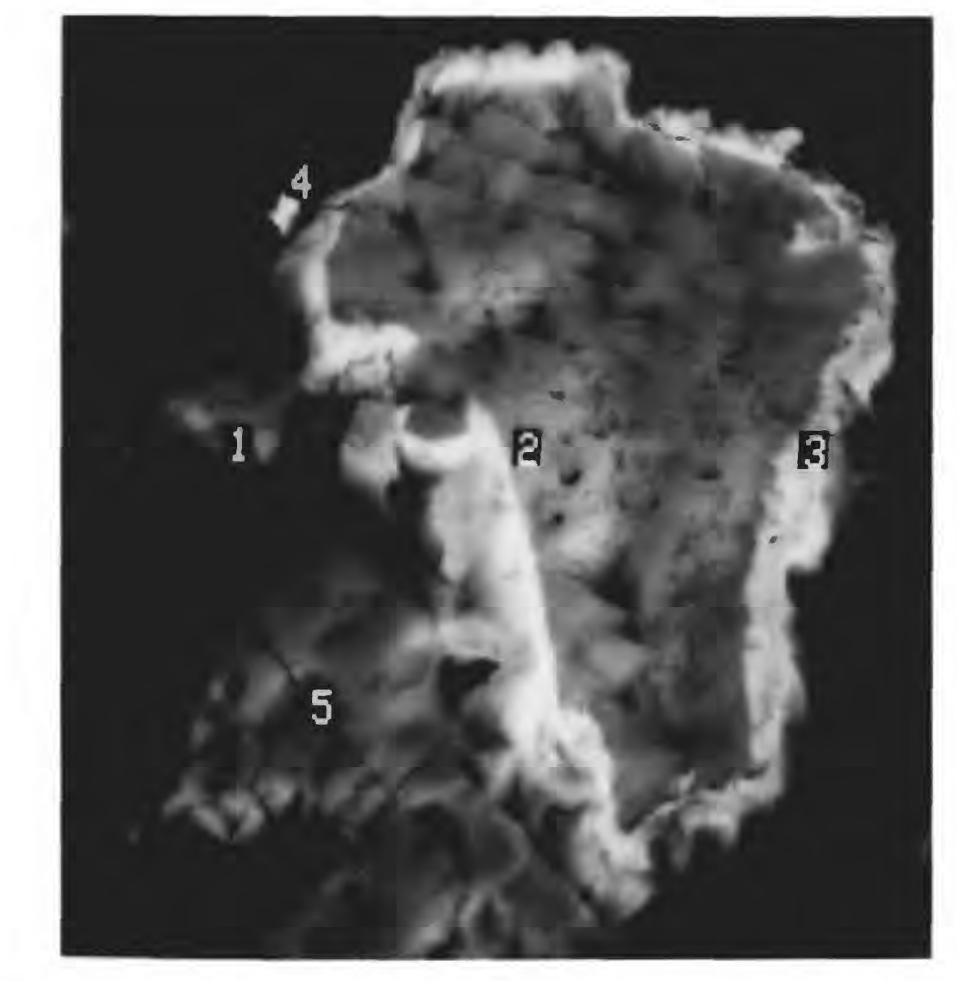

EXPLANATION

1 ALUMINUM, SILICA, POTASSIUM

2 CALCIUM CARBONATE

3 LEAD CARBONATE

4 LEAD SULFIDE

5 DOLOMITE

Figure 24.--Scanning electron photomicrograph of bed sediment showing lead carbonate coating a carbonate particle from site 10 .

compared to values greater than $500 \mu \mathrm{g} / \mathrm{g}$ (for the fine fraction) at sites 1 and 7 . Barium concentrations at all sites were less than $1,000 \mu \mathrm{g} / \mathrm{g}$, except at site 12 . The large barium concentrations $(1,500$ to $2,900 \mu \mathrm{g} / \mathrm{g}$ in the fine fraction and 2,300 to $4,300 \mu \mathrm{g} / \mathrm{g}$ in the coarse fraction) at site 12 probably were caused by the barium-rich sediment entering from the Mineral Fork basin. Barium concentrations were larger in the fine fraction, except at site 12 where the coarse fraction contained about one-third more barium than the fine fraction.

Cadmium concentrations in bed sediment generally were less than $100 \mu \mathrm{g} / \mathrm{g}$ (fig. 26) at sites in both the Big River and the Flat River basins. In both size fractions, cadmium concentrations substantially increased from site 1 to site 3 on the Big River, but decreased downstream from site 3, possibly because the heavier minerals were trapped above the low-water crossing downstream from site 3. In the Flat River, the cadmium concentrations increased from site 7 (less than the detection limit of $2 \mu \mathrm{g} / \mathrm{g}$ ) to site 11 (less than $15 \mu \mathrm{g} / \mathrm{g}$ in both size fractions), possibly because of inflow from the Elvins tailings pile (relatively large concentrations of cadmium were detected at sites 8 and 9). The bed sediment at site 10 had the smallest cadmium concentrations of any of the seepage sites.

Cobalt concentrations in bed sediment generally were less than $150 \mu \mathrm{g} / \mathrm{g}$ at all sites except sites 8 and 9 (fig. 26). The cobalt concentrations at site $9(650$ to $2,300 \mu \mathrm{g} / \mathrm{g})$ were more than double those at site 8 . At all sites, cobalt concentrations were larger in the fine fraction than in the coarse fraction.

Copper concentrations were small at most river sites in the Big River and the Flat River, but generally were larger at the seepage sites. Copper concentrations in bed sediment generally were less than $75 \mu \mathrm{g} / \mathrm{g}$ at sites $1,3,6,7$, and 12 , but were as much as $540 \mu \mathrm{g} / \mathrm{g}$ at site 11 (fig. 26). Copper concentrations in bed sediment in the Big River at sites 6 and 12 generally were about double those at sites 1 and 3. It is likely that the copper concentrations at seepage site 5 were contributing to the large concentrations detected at river site 6 . However, the anomalous copper values at site 11 cannot be 


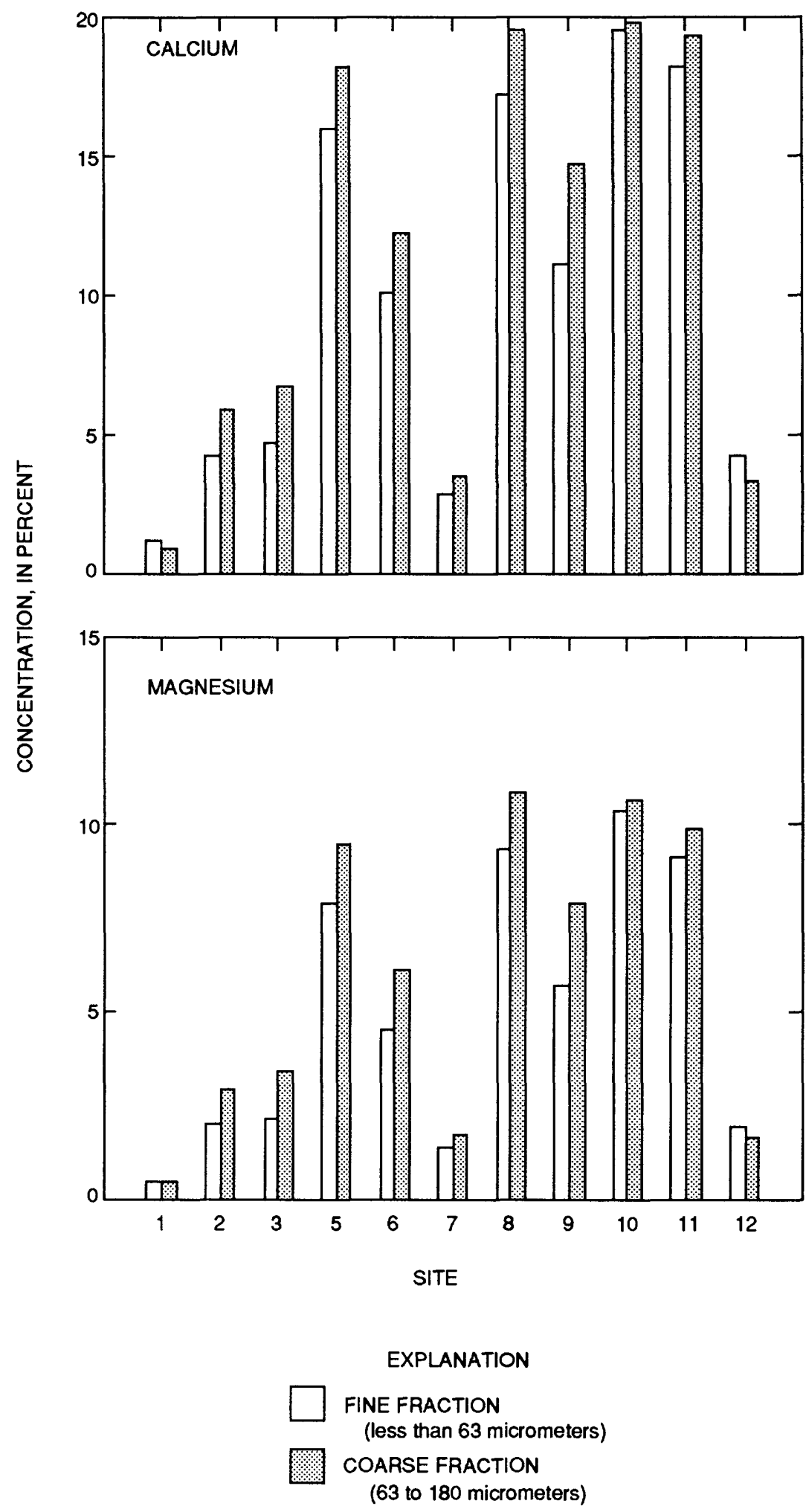

Figure 25.--Mean concentrations of calcium and magnesium in fine and coarse fractions of bed sediment. 

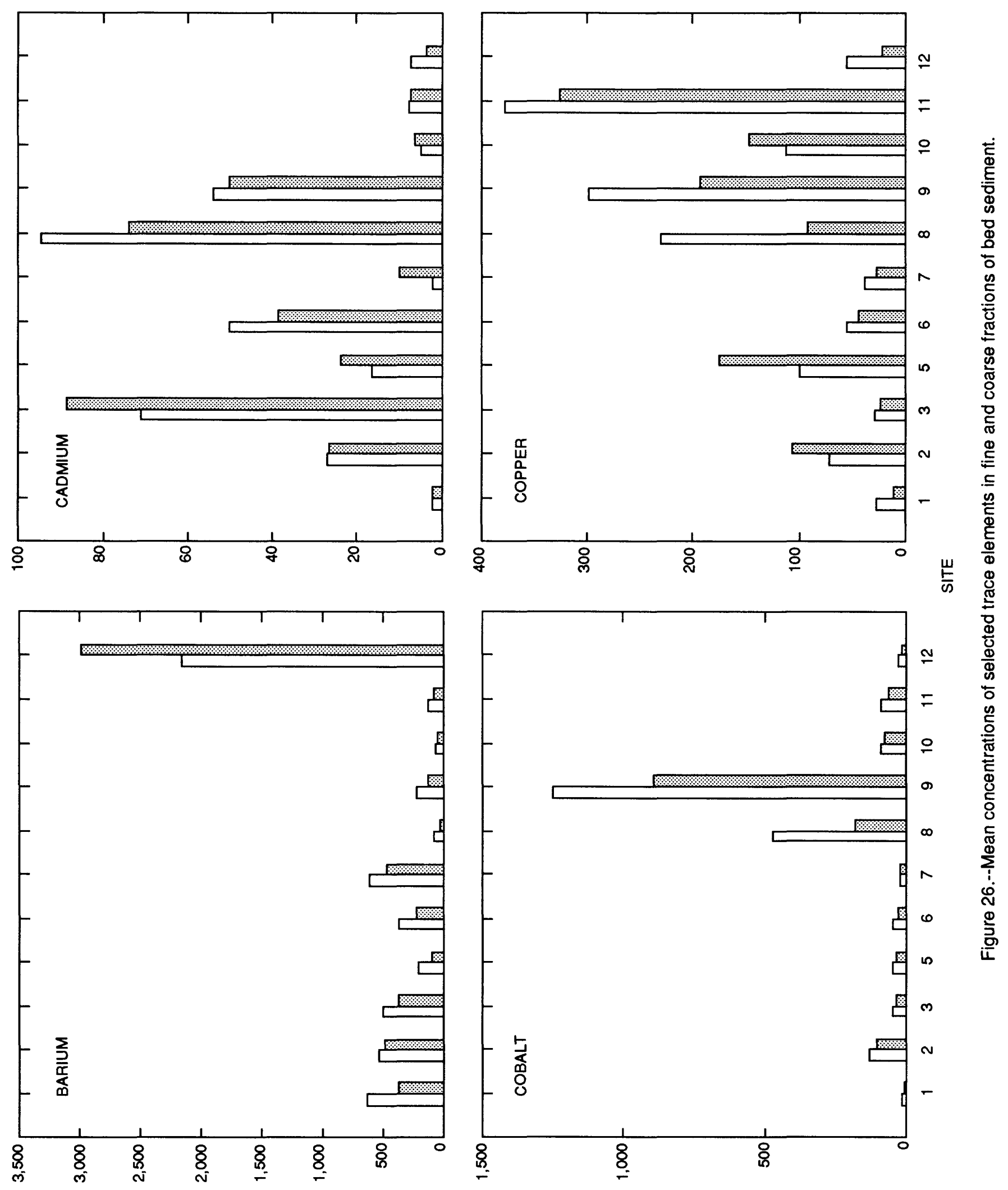

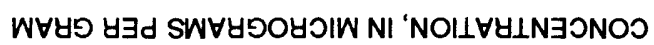



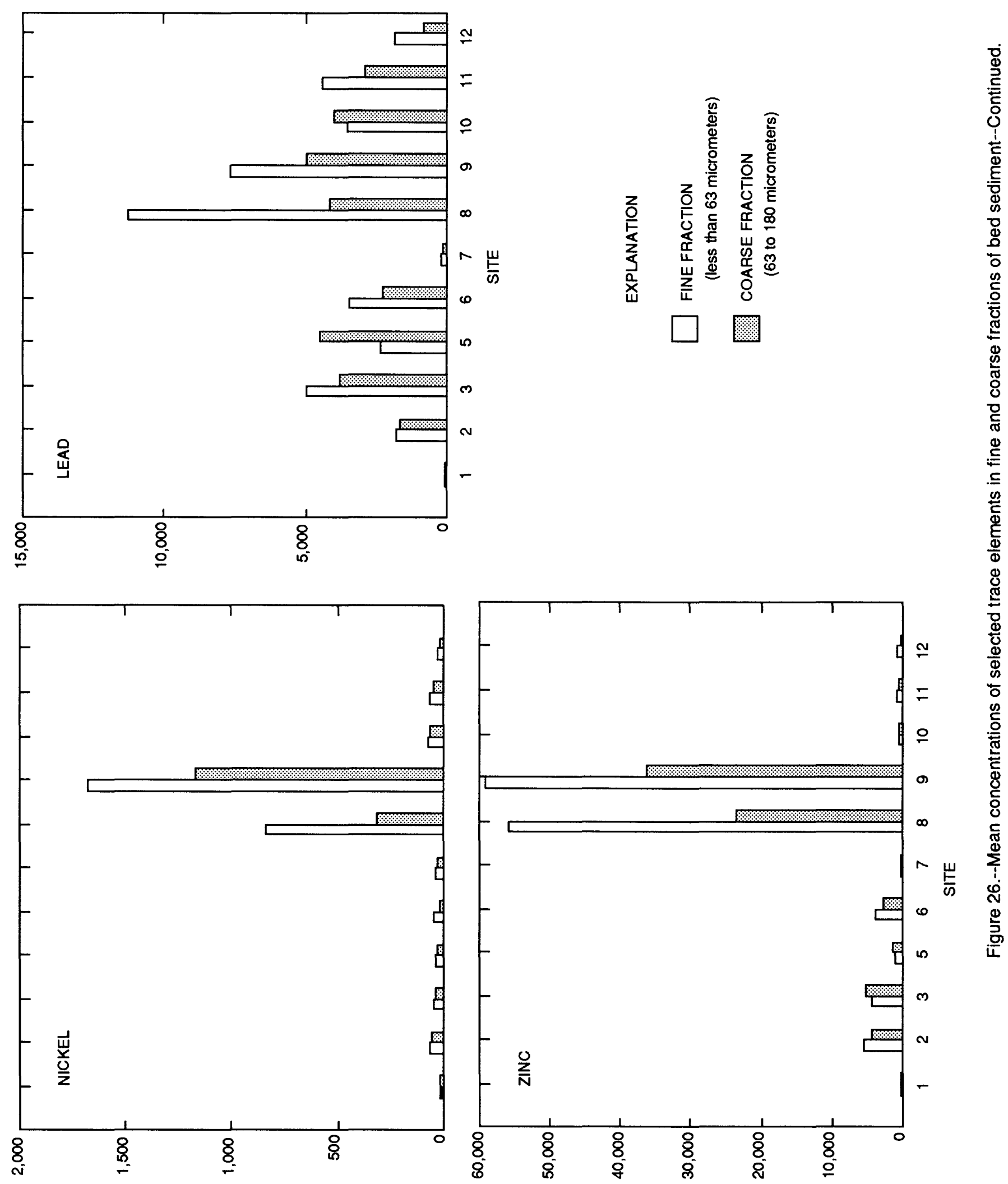

WVYפ 
explained by contributions from the tailings seeps monitored upstream (sites 8, 9, and 10) in this study. Consequently, other sources of copper, such as seepage from the Federal tailings pile (not sampled), could be contributing substantial quantities of copper.

The distribution of nickel in bed sediment in the study area was similar to that of cobalt because these elements were detected in large quantities only at sites 8 and 9 . With the exception of these two sites, nickel concentrations at all sites in both size fractions were less than $125 \mu \mathrm{g} / \mathrm{g}$. The nickel concentrations in both fractions of bed sediment ranged from 95 to $1,200 \mu \mathrm{g} / \mathrm{g}$ at site 8 and from 440 to $3,300 \mu \mathrm{g} / \mathrm{g}$ at site 9 . The cobalt-nickel sulfide, siegenite, is present in minor quantities in the Old Lead Belt, and, in the eastern and southern parts of the Old Lead Belt, siegenite occurs in seams as thick as 3 in. along bedding planes (Snyder and Gerdemann, 1968). The downstream site on the Flat River (site 11) had bed sediment with the largest cobalt and nickel concentrations of the river sites. The cobalt and nickel concentrations at that site likely were related to tailings from the Elvins or Federal tailings piles.

The lead concentrations in bed sediment increased between the most upstream and most downstream sites on the Big River and the Flat River. Lead concentrations in bed sediment increased substantially from site 1 to site 3 (fig. 26) and decreased from site 3 to site 6 and from site 6 to site 12 . However, the concentration of lead at site 12 was substantially larger than at site 1 . The large lead concentration at site 3 (mean concentration of about $5,000 \mu \mathrm{g} / \mathrm{g}$ in the fine fraction and about $3,800 \mu \mathrm{g} / \mathrm{g}$ in the coarse fraction) was considered anomalous because the concentration was significantly larger than the concentrations in tailings at the Leadwood tailings pile upstream from this site (site 2; mean concentration of about $1,800 \mu \mathrm{g} / \mathrm{g}$ in the fine fraction and about $1,700 \mu \mathrm{g} / \mathrm{g}$ in the coarse fraction). This could be the result of trapping of denser material behind the low-water crossing at site 3 . Lead concentrations in bed sediment at site 6 ranged from 1,700 to $3,800 \mu \mathrm{g} / \mathrm{g}$ in the fine fraction and from 1,700 to $3,300 \mu \mathrm{g} / \mathrm{g}$ in the coarse fraction. Similarly, the lead concentrations in the Flat River increased substantially from site 7 (130 to $230 \mu \mathrm{g} / \mathrm{g}$ in the fine fraction and 88 to $180 \mu \mathrm{g} / \mathrm{g}$ in the coarse fraction) to site $11(3,100$ to $5,500 \mu \mathrm{g} / \mathrm{g}$ in the fine fraction and 1,700 to $6,100 \mu \mathrm{g} / \mathrm{g}$ in the coarse fraction).

The mean lead concentration in the coarse fraction of bed material at the seepage sites was relatively consistent, ranging from about 4,000 to about $5,000 \mu \mathrm{g} / \mathrm{g}$ (fig. 26). Furthermore, at site 8 , the lead concentrations in the fine fraction were almost three times the concentration in the coarse fraction. The difference in lead concentration in the two size fractions of bed sediment can be related to milling techniques used to remove lead (in galena) from the raw ore by density separation because the techniques were not as efficient in concentrating lead from the extremely small particles. The relatively uniform lead concentration in the coarse fraction at the seepage sites and the variation in the fine fraction probably reflect the efficiency of the separation techniques.

Zinc concentrations in bed sediment in the Big River and the Flat River also increased between the most upstream and most downstream sites. Zinc concentrations in bed sediment increased substantially from site 1 to site 3 and decreased from site 3 to site 6 and from site 6 to site 12 (fig. 26). Zinc concentrations in bed sediment at site 6 ranged from 1,800 to $8,100 \mu \mathrm{g} / \mathrm{g}$. Zinc concentrations at site 12 were substantially larger than at site 1 . Similarly, the zinc concentrations in the Flat River increased substantially from site 7 to site 11 . Zinc concentrations in bed sediment at site 11 ranged from 380 to $960 \mu \mathrm{g} / \mathrm{g}$.

The zinc concentrations in the coarse fraction of bed material at the seepage sites varied considerably. The zinc concentrations in the coarse fraction ranged from 1,600 to $6,900 \mu \mathrm{g} / \mathrm{g}$ at site 2; from 620 to $1,900 \mu \mathrm{g} / \mathrm{g}$ at site 5 ; from 9,000 to $51,000 \mu \mathrm{g} / \mathrm{g}$ at site 8 ; from 26,000 to $63,000 \mu \mathrm{g} / \mathrm{g}$ at site 9; and from 280 to $470 \mu \mathrm{g} / \mathrm{g}$ at site 10 . The zinc concentrations in the fine fraction of bed sediment at the seepage sites generally were larger than the zinc concentrations in the coarse fraction. Both size fractions of bed sediment at sites 8 and 9 contained zinc in concentrations 5 to 10 times those at the other seepage sites. 
Cadmium, lead, and zinc concentrations in bed sediment in the Big River all increased from site 1 to site 3 and decreased from site 3 to site 6 . The large cadmium, lead, and zinc concentrations at site 3 probably are because of the trapping of denser metal-rich particles behind the low-water crossing. Positive correlations existed between cadmium and zinc concentrations in the fine fraction $\left(\mathrm{r}^{2}=0.88\right)$ and coarse fraction $\left(\mathrm{r}^{2}=0.93\right)$ of bed sediment in the Big River at sites 3, 6, and 12 (fig. 27). This relation indicated similar phase associations for cadmium and zinc in both fractions. A positive correlation of cobalt and nickel also was detected in the fine fraction $\left(\mathrm{r}^{2}=0.93\right)$ and the coarse fraction $\left(r^{2}=0.76\right.$; fig. 28) which indicates a similar source for cobalt and nickel, such as siegenite. A positive correlation was noted between the logarithms of zinc and lead concentrations in both size fractions $\left(\mathrm{r}^{2}\right.$ $=0.88$ for the fine fraction and $r^{2}=0.88$ for the coarse fraction; fig. 29). For samples from site 12, the lead to zinc ratio was larger than expected. This could be because of large concentrations of lead in sediment from Mineral Fork or because of the relative insolubility of lead-bearing phases and dissolution of zinc-bearing minerals in the bed sediment.

\section{GEOCHEMICAL CONTROLS ON WATER QUALITY}

To investigate thermodynamic controls on water quality, equilibrium-speciation calculations were made using the geochemical program codes WATEQ4F (Ball and others, 1987) and PHREEQE (Parkhurst and others, 1980) for the seepage sites. Only seepage sites were selected for these calculations because of their relatively small variation in water quality and bed sediment, which enabled verification of proposed solid-phase controls by analysis of associated bed sediment and precipitates. These calculations provided the probable speciation of aqueous constituents based on thermodynamic association constants and saturation indices (SI) of minerals phases that may be reacting in the system (table 10 ). The SI of a given mineral is described by the equation

$$
\mathrm{SI}=\log \mathrm{IAP} / \mathrm{K}_{\mathrm{t}}
$$

where IAP is the ion activity product of the mineral-water reaction, and $\mathrm{K}_{\mathrm{t}}$ is the thermodynamic equilibrium constant of the mineral at the temperature of the water. For example, to determine the SI of calcite for the dissociation reaction

$$
\mathrm{CaCO}_{3}=\mathrm{Ca}^{2+}+\mathrm{CO}_{3}{ }^{2-} \text {, }
$$

the mass-action equation can be written as

$$
\text { Kcalcite }=\mathrm{ACa}^{2+} \times \mathrm{ACO}_{3}{ }^{2-} / \mathrm{ACaCO}_{3},
$$

where $\mathbf{A}$ is the activity of a given species in solution. Activities of pure solids generally are considered to be unity and the equation simplifies to

$$
\text { Kcalcite }=\mathrm{ACa}^{2+} \times \mathrm{ACO}_{3}{ }^{2-} .
$$

The SI is calculated by substituting the measured constituent activities into equation 5 and dividing by the appropriate equilibrium constant. In natural systems, a steady-state equilibrium may be achieved between the aqueous phase and solid phase, providing reaction kinetics are rapid compared to residence times. If these conditions are disturbed, such as with the addition of a calcium-rich waste water to a system in equilibrium with calcite, reactions will occur (in this case precipitation of calcite) to re-establish equilibrium. An important limitation on the use of thermodynamic equilibrium calculations is that reaction kinetics are not considered and generally are 


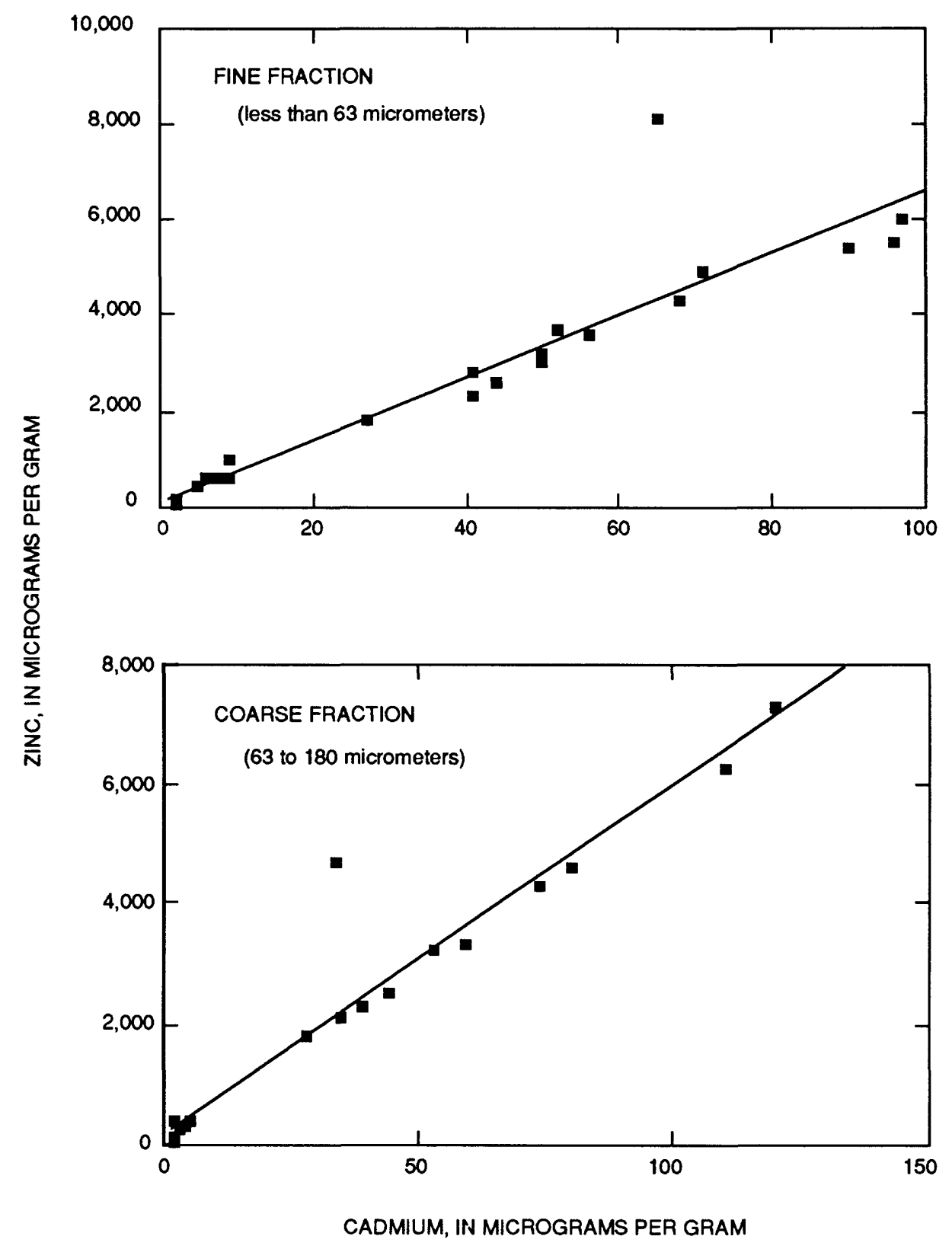

Figure 27.--Relation between concentrations of zinc and cadmium in bed sediment in the Big River. 

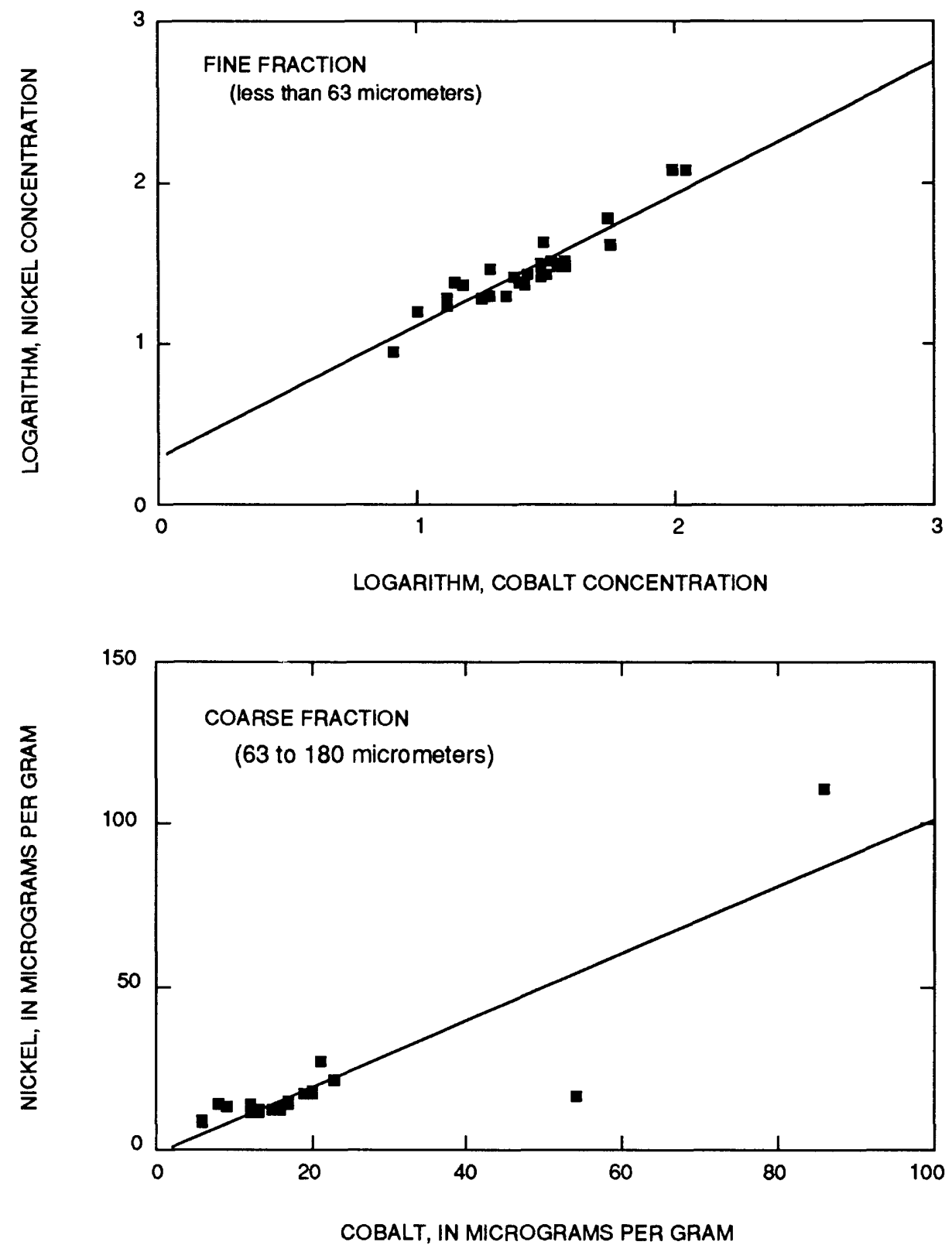

Figure 28.--Relation between concentrations of nickel and cobalt in bed sediment in the Big River. 


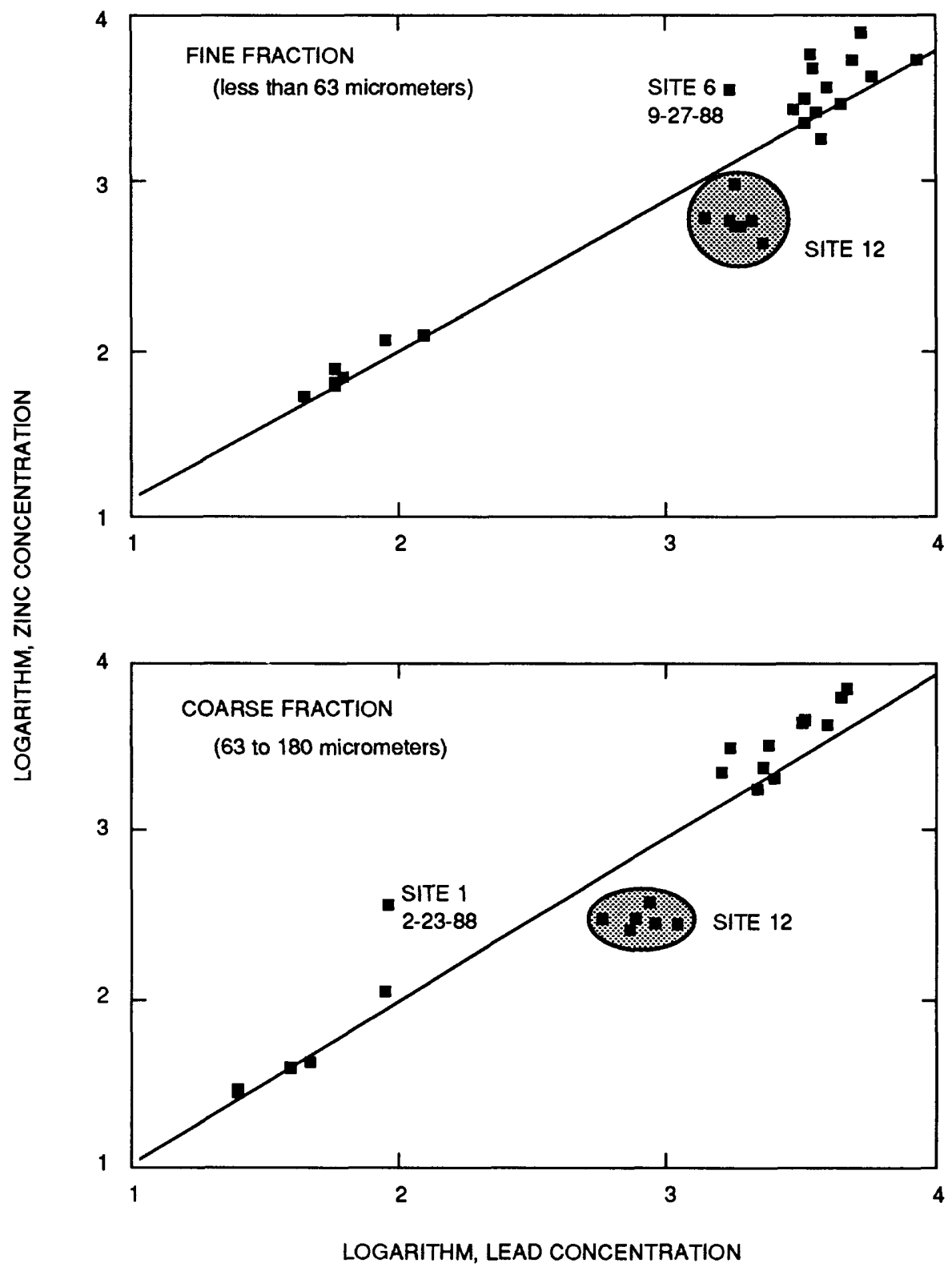

Figure 29.--Relation between concentrations of zinc and lead in bed sediment in the Big River. 


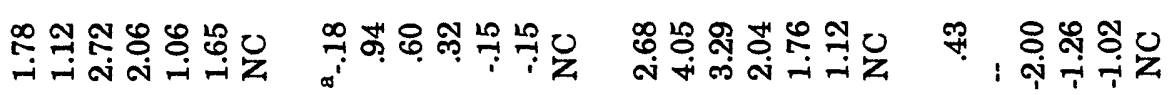

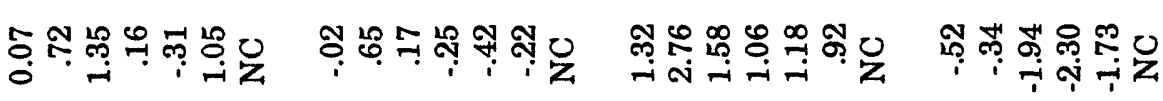

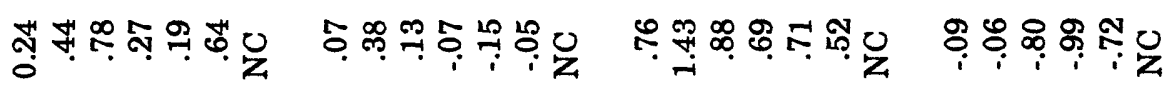

离各

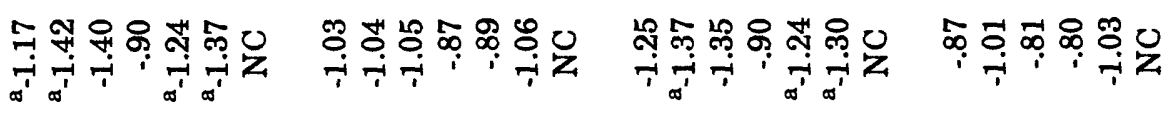

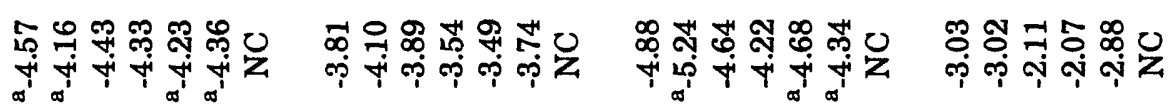

000 운

งิ

o

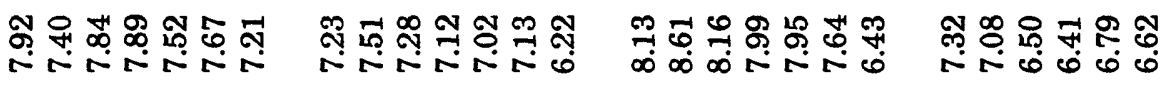

$\infty \infty \infty \infty \infty$

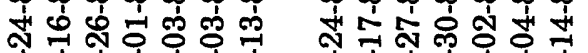

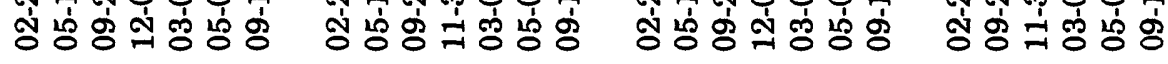

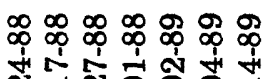

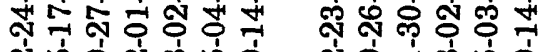

密

N

4

is

$\infty$ 


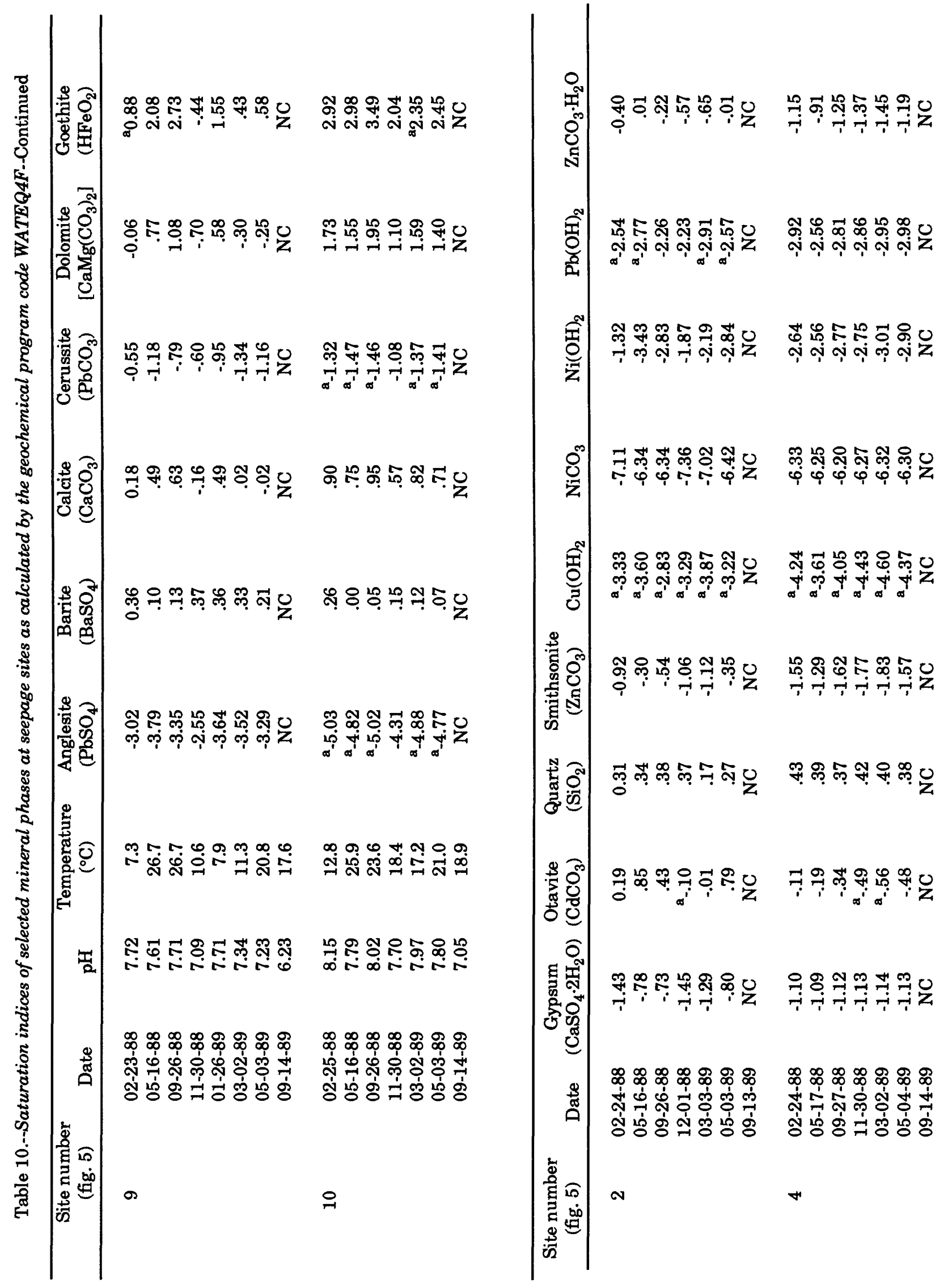




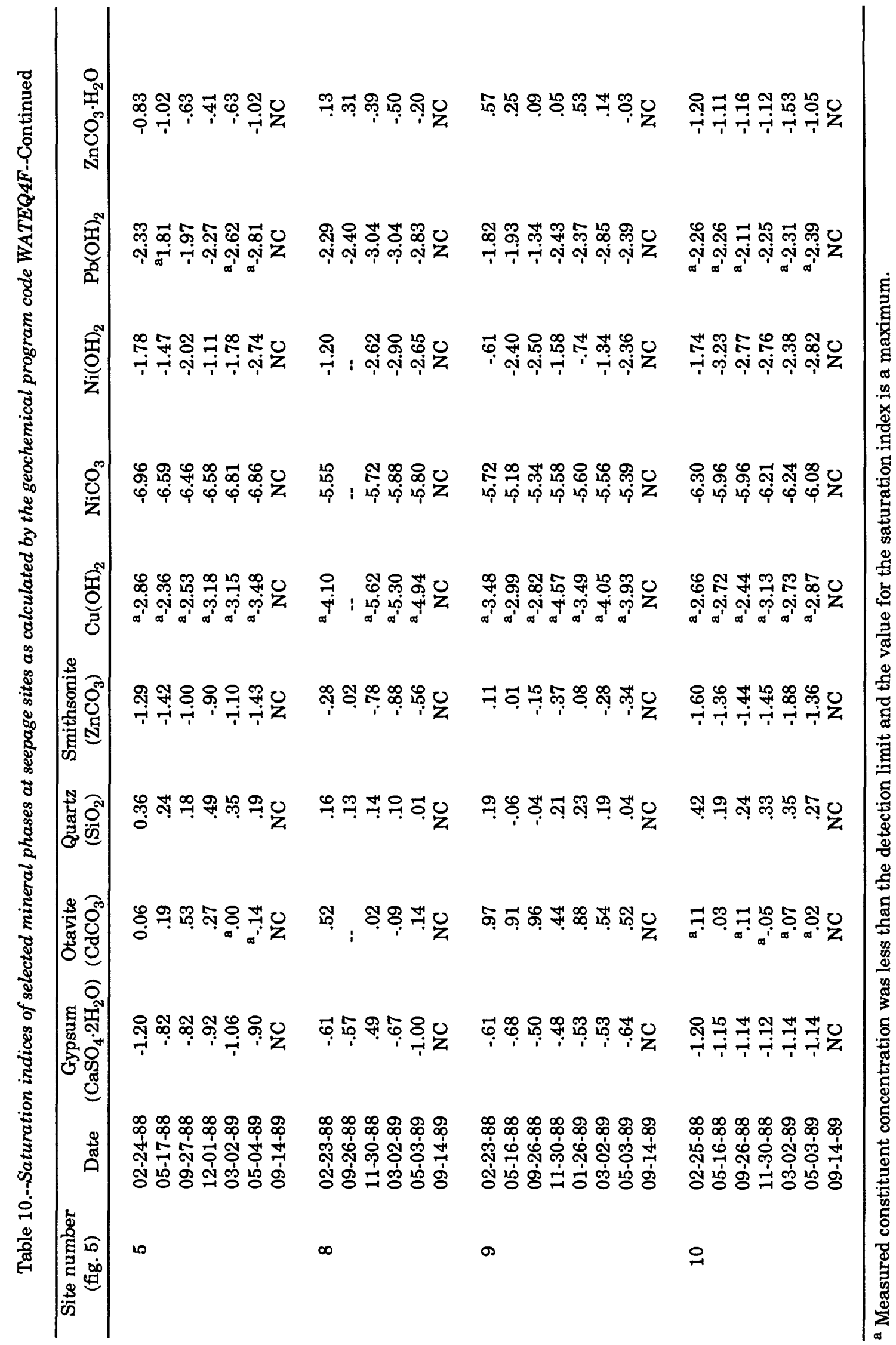


poorly understood for many phases. A mineral with an SI greater than zero indicates a mineral phase is thermodynamically supersaturated. This does not necessarily indicate that a given phase will precipitate.

Equilibrium-speciation calculations using the geochemical program code WATEQ4F (Ball and others, 1987) indicated that barite was at equilibrium at all seepage sites (table 9). These calculations also indicated that calcite and dolomite generally were at or near equilibrium or slightly supersaturated at the seepage sites and that gypsum generally was undersaturated at these sites.

Lead was slightly undersaturated with respect to cerussite (lead carbonate) at all seeps (a lead concentration of $10 \mu \mathrm{g} / \mathrm{L}$ was assumed where the concentration was reported to be less than the detection limit of $10 \mu \mathrm{g} / \mathrm{L}$ ). The SI ranged from -0.6 to -1.47 , but uncertainty in the thermodynamic data for trace elements is large; therefore, cerussite could be at or near equilibrium. Plausible controls on the aqueous concentration of lead could be the formation of lead carbonate (the scanning electron microscope indicated the presence of lead carbonate and lead oxide in bed-sediment samples) and lead oxides or the ability of lead to sorb readily to oxides and clay particles.

Although the concentrations of other trace elements were small, caused in part by the near neutral $\mathrm{pH}$ values and their insolubility in an alkaline bicarbonate-rich environment, large concentrations of zinc in solution did exist, especially at the Elvins tailings pile (sites 8 and 9). The SI values from WATEQ4F indicated a hydrated zinc carbonate phase was at equilibrium at sites $2,5,8$, and 9 (SI values from -1.02 to 0.57 ). At site 8, a milky white precipitate cemented individual grains together in the channel bottom (fig. 23). Analysis of this precipitate and associated grains by scanning electron microscope and $x$-ray diffraction indicated this phase was a hydrated zinc carbonate, possibly smithsonite $\left(\mathrm{ZnCO}_{3}\right)$, confirming the equilibrium-speciation calculations. The fact that this phase was only observed on dolomite grains, and not calcite grains, may indicate the dolomite surface serves as a nucleation site for precipitation of zinc carbonate. Because this phase was detected in bed-sediment samples from site 8 , precipitation of this phase is a likely control on the aqueous concentrations of zinc.

Because cadmium usually is present in sphalerite, there were increased concentrations of cadmium at sites 8 and 9 and most other seepage sites (a cadmium concentration of $1 \mu \mathrm{g} / \mathrm{L}$ was used in the WATEQ4F calculations when the measured concentration was reported to be less than the detection limit of $1 \mu \mathrm{g} / \mathrm{L}$ ). The control on cadmium at the seepage sites may be the solubility of cadmium carbonate (otavite) because the SI indicated saturation or supersaturation (table 10).

At seepage sites in the Old Lead Belt, $\mathrm{pH}$ values ranged from 6.2 to 8.6. Cadmium concentrations ranged from less than 1 to $28 \mu \mathrm{g} / \mathrm{L}$; cobalt concentrations ranged from less than 3 to $610 \mu \mathrm{g} / \mathrm{L}$; copper concentrations were less than or equal to $10 \mu \mathrm{g} / \mathrm{L}$; iron concentrations ranged from less than 3 to $60 \mu \mathrm{g} / \mathrm{L}$; lead concentrations ranged from less than 10 to $80 \mu \mathrm{g} / \mathrm{L}$; nickel concentrations ranged from 10 to $640 \mu \mathrm{g} / \mathrm{L}$; and zinc concentrations ranged from 120 to $18,000 \mu \mathrm{g} / \mathrm{L}$ (all concentrations were dissolved). Nearly all the flow from seepage sites was in equilibrium with respect to calcite and dolomite. The presence of large quantities of carbonate minerals in tailings in the Old Lead Belt tends to limit aqueous concentrations of many trace elements by the formation of less soluble carbonate and oxide complexes. This situation is in contrast to that in the Tri-State District of southwestern Missouri, southeastern Kansas, and northeastern Oklahoma. Mineralization in the Tri-State District generally is within silicified breccia that lacks appreciable quantities of carbonate rocks, and, therefore, acid-forming reactions are not buffered by the dissolution of carbonate minerals. For the Tri-State District, $\mathrm{pH}$ values in mine water (Spruill, 1987) and seepage associated with tailings piles (Barks, 1977) were as low as 3.5 and large concentrations of dissolved trace elements have been detected in seepage from tailings piles. Aluminum concentrations ranged from 0 to $4,200 \mu \mathrm{g} / \mathrm{L}$; cadmium concentrations ranged from 1 to $74 \mu \mathrm{g} / \mathrm{L}$; cobalt concentrations ranged from 0 to $10 \mu \mathrm{g} / \mathrm{L}$; copper concentrations ranged from 0 to $350 \mu \mathrm{g} / \mathrm{L}$; iron concentrations ranged from 10 to $390 \mu \mathrm{g} / \mathrm{L}$; lead concentrations ranged from 0 to $1,300 \mu \mathrm{g} / \mathrm{L}$; nickel concentrations ranged from 4 to $30 \mu \mathrm{g} / \mathrm{L}$; and zinc concentrations ranged from 540 to $35,000 \mu g / L$ (Barks, 1977). 
Some of the possible geochemical reactions within the mines and adjacent to the tailings piles in the Old Lead Belt were investigated using the geochemical program code PHREEQE (Parkhurst and others, 1980). In these simulations, water moving through the St. Francois aquifer with a chemical composition as determined from analyses of water from a public-drinking water supply well was assumed to come into contact with the minerals in abandoned, flooded mines. Three separate hypotheses were simulated based on assumptions that the mine cavities were (1) closed to atmospheric oxygen, (2) completely open to atmospheric oxygen, and (3) partially open to atmospheric oxygen. Results of the simulation were compared to water-quality data for samples collected from a flowing drill hole open to the mine cavity system (site 4). Because the mined cavities are between 200 and 300 $\mathrm{ft}$ below land surface, they were assumed to be closed to atmospheric oxygen in the first simulation. In this simulation, oxidation of pyrite and other sulfide minerals would consume any available oxygen producing iron oxides and dissolved sulfate, thereby lowering the $\mathrm{pH}$ value. In this simulation, the system was buffered by the dissolution of carbonate minerals present. However, simulated calcium, magnesium, and sulfate concentrations were 66,42 , and $54 \mathrm{mg} / \mathrm{L}$, as compared to measured concentrations of 110,64 , and $260 \mathrm{mg} / \mathrm{L}$ at site 4 (flowing borehole from the abandoned mines). At site 4, there was not a large quantity of iron present (less than $10 \mu \mathrm{g} / \mathrm{L}$ ), but in an abandoned mine shaft 2 mi southeast of site 4 at River Mines (fig. 1), the dissolved iron concentration ranged from 1,000 to $2,000 \mu \mathrm{g} / \mathrm{L}$. Results of this simulation indicated that oxidation of sulfide minerals in a closed system does not generate the large concentrations of calcium, magnesium, and sulfate detected in water flowing from the abandoned mines.

The second simulation was based on the assumption that the system was open to the atmosphere and abundant quantities of oxygen were available. Simulated concentrations of calcium, magnesium, and sulfate of 132,83 , and $268 \mathrm{mg} / \mathrm{L}$ were similar to concentrations from site 4 . However, the bicarbonate concentration estimated by this simulation was $572 \mathrm{mg} / \mathrm{L}$, compared to the measured concentration (median) of $350 \mathrm{mg} / \mathrm{L}$.

The third simulation treated the system as one that was partially open with some continuous influx of oxygen to the mines. In this simulation, sulfate could be produced from secondary minerals that have formed on the walls of the mines during the more than 100 years that many of the mines were open. These minerals, such as gypsum, would have formed from the oxidation of sulfide minerals that were exposed to oxygen during mining. Estimated concentrations of calcium, magnesium, sulfate, and bicarbonate of $110,70,283$, and $360 \mathrm{mg} / \mathrm{L}$ in this simulation compare favorably to the measured concentrations of $110,64,260$, and $350 \mathrm{mg} / \mathrm{L}$.

To understand more clearly the possible geochemical reactions at the tailings piles, reaction path and mass-transfer calculations were made for site 8 at the Elvins tailings pile. This was the only tailings pile in the study area where water samples were collected directly from seepage emerging at the base of the pile. Based on the constituent concentrations at the other piles, in particular at site 2, it is possible that similar reactions are occurring at other piles and that the constituent concentrations detected during this study reflect dilution and precipitation effects downstream from these piles. At site 8, the system is open to atmospheric oxygen. From WATEQ4F calculations, calcite and dolomite were near saturation at $\mathrm{pH}$ values of about 6.5 to 7.3. In a simulation of the water chemistry at the pile, pure water (with oxygen) was assumed to percolate through the pile. Reactive phases in this simulation were calcite, dolomite, gypsum, pyrite, and iron hydroxides. At equilibrium, calcite and iron hydroxides were precipitated; dolomite and gypsum were dissolved; and pyrite was oxidized. The final solution had a $\mathrm{pH}$ of 6.6 and simulated constituent concentrations of $247 \mathrm{mg} / \mathrm{L}$ calcium; $69 \mathrm{mg} / \mathrm{L}$ magnesium; $758 \mathrm{mg} / \mathrm{L}$ sulfate; and $203 \mathrm{mg} / \mathrm{L}$ bicarbonate, which compared favorably with measured concentrations of $200,66,615$, and $150 \mathrm{mg} / \mathrm{L}$ (Smith and Schumacher, 1991). 


\section{SUMMARY AND CONCLUSIONS}

The Old Lead Belt, which was the Nation's largest producer of lead for almost 50 years, covers $110 \mathrm{mi}^{2}$ in southeastern Missouri. In 1988, concern about the effects of seepage and runoff from the abandoned mines and numerous mine tailings piles, prompted the U.S. Geological Survey, in cooperation with the Missouri Department of Natural Resources, Land Reclamation Commission, to conduct a study of the quality of surface water and bed sediment in the area of the Old Lead Belt.

Water quality at six sites on the two main streams in the study area, the Big River and the Flat River, met the water-quality criteria for the protection of aquatic life and livestock and wildlife watering for the trace elements analyzed for in this study of these rivers as defined by the Missouri Department of Natural Resources, with the exception of one sample from the Flat River that exceeded the water-quality criteria for lead. The concentrations of most major constituents were similar at most sites on these two rivers, with the exception of the most downstream site on the Flat River. At this site, which is downstream from large tailings piles, concentrations of sodium, chloride, and sulfate generally were larger than those at the other river sites. Trace-element concentrations in water at the six river sites generally were small. However, barium concentrations ranged from 180 to $380 \mu \mathrm{g} / \mathrm{L}$ at the most downstream site on the Big River. This site is located downstream from a tributary draining an area mined for barite.

Values of physical properties and concentrations of major constituents in water at six sites associated with seepage from the tailings piles also were determined. Concentrations of major constituents at these sites generally were largest at sites near the Elvins tailings pile where values of specific conductance ranged from 823 to $1,540 \mu \mathrm{S} / \mathrm{cm}$, cadmium concentrations ranged from 14 to $28 \mu \mathrm{g} / \mathrm{L}$, cobalt concentrations ranged from 310 to $610 \mu \mathrm{g} / \mathrm{L}$, lead concentrations ranged from 10 to $80 \mu \mathrm{g} / \mathrm{L}$, and zinc concentrations ranged from 3,500 to $18,000 \mu \mathrm{g} / \mathrm{L}$.

Seepage runs on the Big River and the Flat River, which were made during high base-flow conditions, indicated that discharge in both streams increased slightly downstream. As discharge increased, specific conductance values also increased. At times, inflow from ground-water sources and seepage from the tailings piles had specific conductance values two to three times those of the river water upstream from the mining area. Estimated values of specific conductance at downstream sites were within about 10 percent of measured values when additional discharge was assumed to be water from the abandoned mines. Mass-balance calculations using changes in concentrations of selected constituents between various sites on the Big River indicated that the downstream increase in flow along Big River probably is caused by inflow from the abandoned mines.

During the 19-month period of record at the Big River below Desloge, about 41,000 tons of suspended sediment were transported by the river. A single flood transported about 17,000 tons or about 40 percent of the total suspended-sediment load for the period of record and also transported about 20 tons of barium, 1,200 tons of iron, 90 tons of lead, and 50 tons of zinc. At discharges of less than $258 \mathrm{ft}^{3} / \mathrm{s}$, iron and lead seem to be transported primarily in the suspended solid phase, and barium and zinc seem to be transported primarily in the dissolved phase.

Bed sediment at river sites that are unaffected by mining was composed mainly of quartz. Bed sediment at river sites affected by mining and sites receiving seepage from the tailings piles was composed mainly of carbonate minerals, primarily dolomite and ankerite.

Phase associations in the bed sediment at all sites indicated that most of the trace elements were associated with the carbonate, oxide, and sulfide phases. At the Elvins tailings pile, zinc associated with the carbonate phase was detected in large quantities, primarily as zinc carbonate coatings on dolomite particles. 
In the Big River, the largest trace-element concentrations in bed sediment generally were at site 3, downstream from the Leadwood tailings pile. Except for barium, trace-element concentrations in bed sediment generally were smaller at site 6 and smaller yet at site 12 , the most downstream site on the Big River, than at site 3, but remained larger than concentrations at site 1 . At site 3 , cadmium concentrations ranged from 44 to $120 \mu \mathrm{g} / \mathrm{g}$, lead concentrations ranged from 2,400 to $8,500 \mu \mathrm{g} / \mathrm{g}$, nickel concentrations ranged from 15 to $118 \mu \mathrm{g} / \mathrm{g}$, and zinc concentrations ranged from 2,600 to $7,300 \mu \mathrm{g} / \mathrm{g}$. Large barium concentrations $(1,500$ to $4,300 \mu \mathrm{g} / \mathrm{g})$ were detected in bed sediment at site 12 , probably as a result of barite mining within the Mineral Fork basin. In the Flat River, trace-element concentrations in bed sediment increased from site 7 upstream from the mined area to site 11 downstream from the mined area. At site 11, copper concentrations ranged from 230 to $540 \mu \mathrm{g} / \mathrm{g}$; lead concentrations ranged from 1,700 to $6,100 \mu \mathrm{g} / \mathrm{g}$; nickel concentrations ranged from 23 to $82 \mu \mathrm{g} / \mathrm{g}$; and zinc concentrations ranged from 380 to $960 \mu \mathrm{g} / \mathrm{g}$.

Largest concentrations of trace elements in bed sediment at seepage sites were detected at two sites near the Elvins tailings pile. Cobalt concentrations at these sites ranged from 79 to $2,500 \mu \mathrm{g} / \mathrm{g}$, copper concentrations ranged from 69 to $450 \mu \mathrm{g} / \mathrm{g}$, lead concentrations ranged from 2,800 to 38,000 $\mu \mathrm{g} / \mathrm{g}$, nickel concentrations ranged from 95 to $3,200 \mu \mathrm{g} / \mathrm{g}$, and zinc concentrations ranged from 9,000 to more than $100,000 \mu \mathrm{g} / \mathrm{g}$.

In water samples collected at seepage sites, dolomite and calcite generally were at or near saturation with respect to calcite and dolomite and undersaturated with respect to gypsum. Seepage at those sites was slightly undersaturated with respect to lead carbonate. Smithsonite and a hydrated zinc carbonate phase were at saturation in water from several of the seepage sites. Zinc carbonate precipitates were detected as coatings on dolomite particles at the Elvins tailings pile. The solubility of carbonate phases probably controls aqueous concentrations of cadmium, lead, and zinc. In addition, lead and zinc were associated with secondary oxide and carbonate phases in stream sediment, indicating sorption and coprecipitation are likely controls on aqueous concentrations. A zinc carbonate precipitate was detected at one seepage site. Dolomite grains probably serve as nucleation sites for these precipitates.

Simulation of geochemical reactions indicate that the hydrologic system that exists in abandoned mines of the Old Lead Belt probably is at least partially open to the atmosphere. The oxidation of sulfide minerals and production of hydrogen ions and subsequent buffering and neutralization by dissolution of carbonate minerals that seems to be occurring indicates a source of oxygen to the system. Sources of sulfate (concentrations larger than $250 \mathrm{mg} / \mathrm{L}$ ) in seeps from the abandoned mines could be the oxidation of secondary minerals formed during the operation of the mines. 


\section{REFERENCES CITED}

Association of Missouri Geologists, 1969, Major geologic features of lead and barite districts of southeast Missouri--16th annual field trip guide: Viburnum, Mo., $24 \mathrm{p}$.

Ball, J.W., Nordstrom, D.K, and Zachmann, D.W., 1987, WATEQ4F--A personal computer Fortran translation of the geochemical model WATEQ2 with revised data base: U.S. Geological Survey Open-File Report 87-50, 108 p.

Barks, J.H., 1977, Effects of abandoned lead and zinc mines and tailings piles on water quality in the Joplin area, Missouri: U.S. Geological Survey Water-Resources Investigations 77-75, 49 p.

Davis, J.H., 1960, Mineralization in the southeast Missouri lead district: Madison, University of Wisconsin, unpublished Ph.D. dissertation, 68 p.

Elliott, L.E., 1982, Impacts of tailings from abandoned lead mines on the water quality and sediments of Flat River Creek and Big River in southeastern Missouri: University of Missouri-Rolla, unpublished M.S. thesis, $63 \mathrm{p}$.

Fenneman, N.M., 1938, Physiography of eastern United States: New York, McGraw Hill, 714 p.

Imes, J.L., 1990, Major geohydrologic units in and adjacent to the Ozark Plateaus Province, Missouri, Arkansas, Kansas, and Oklahoma--St. Francois aquifer: U.S. Geological Survey Hydrologic Investigations Atlas HA-711-C, 2 sheets.

Imes, J.L., and Smith, B.J., 1990, Areal extent, stratigraphic relation, and geohydrologic properties of regional geohydrologic units in southern Missouri: U.S. Geological Survey Hydrologic Investigations Atlas HA-711-I, 3 sheets.

Koenig, J.W., ed., 1961, The stratigraphic succession in Missouri: Rolla, Missouri Division of Geology and Land Survey, v. XL, 2d series, 185 p.

Kramer, R.L., 1976, Effects of a century old Missouri lead mining operation upon the water quality, sediments and biota of Flat River Creek: University of Missouri-Rolla, unpublished M.S. thesis, $111 \mathrm{p}$.

McCracken, M.H., 1971, Structural features of Missouri: Rolla, Missouri Division of Geology and Land Survey Report of Investigations 49, $99 \mathrm{p}$.

Missouri Department of Natural Resources, 1986, Missouri water atlas: Rolla, Missouri Division of Geology and Land Survey, $97 \mathrm{p}$.

1987, Missouri water quality standards--Chapter 7, Water quality: Jefferson City, Clean Water Commission, $79 \mathrm{p}$.

Missouri Water Pollution Board, 1964, Water quality of the Big, Bourbeuse, and Meramec River basins: Jefferson City, 65 p.

National Oceanic and Atmospheric Administration, 1988, Climatological data, Missouri: Asheville, N.C., National Climatic Data Center, v. 92, no. 1-12. 


\section{REFERENCES CITED--Continued}

Novak, J.T., and Hasselwander, G.B., 1980, Control of mine tailing discharges to Big River: Jefferson City, Missouri Department of Natural Resources, 75 p.

Parkhurst, D.L., Thorstenson, D.C., and Plummer, L.N., 1980, PHREEQE--A computer program for geochemical calculations: U.S. Geological Survey Water-Resources Investigations 80-96, $193 \mathrm{p}$.

Schmitt, C.J., and Finger, S.E., 1982, The dynamics of metals from past and present mining activities in the Big and Black River watersheds, southeastern Missouri: U.S. Fish and Wildlife Service, $153 \mathrm{p}$.

Skelton, John, 1976, Missouri stream and springflow characteristics--Low-flow frequency and flow duration: Rolla, Missouri Division of Geology and Land Survey Water Resources Report 32, $71 \mathrm{p}$.

Smith, B.J., 1988, Assessment of water quality in non-coal mining areas of Missouri: U.S. Geological Survey Water-Resources Investigations Report 87-4286, 50 p.

Smith, B.J., and Schumacher, J.G., 1991, Hydrochemical and sediment data for the Old Lead Belt, southeastern Missouri--1988-89: U.S. Geological Survey Open-File Report 91-211, 98 p.

Snyder, F.G., and Gerdemann, P.E., 1968, Geology of the southeast Missouri lead district, in Ridge, J.S., ed., Ore deposits of the United States, 1933-1967: New York, American Institute of Mining, Metallurgical, and Petroleum Engineers, Inc., p. 326-369.

Spruill, T.B., 1987, Assessment of water resources in lead-zinc mined areas in Cherokee County, Kansas, and adjacent areas: U.S. Geological Survey Water-Supply Paper 2268, 68 p.

Tukey, J.W., 1977, Exploratory data analysis: Reading, Mass., Addison-Wesley, 688 p.

U.S. Geological Survey, and Missouri Division of Geology and Land Survey, 1967, Mineral and water resources of Missouri: U.S. 90th Congress, 1st Session, Senate Document 19, 399 p.; also Missouri Division of Geology and Land Survey, v. XLIII, 2d series, 399 p.

Waite, L.A., Davis, J.V., Reed, H.L., Hatten, D.O., and Perkins, T.J., 1989, Water resources data Missouri water year 1988: U.S. Geological Survey Water-Data Report MO-88-1, 287 p. (published annually).

1990, Water resources data Missouri water year 1989: U.S. Geological Survey Water-Data Report MO-89-1, 353 p. (published annually).

Wharton, H.M., Larsen, K.G., Sweeney, P.H., Harrison, Ed, Bradley, Milton, Davis, J.H., Rogers, R.K., Brown, W.J., Paarlberg, N.L., Evans, L.L., Mouat, M.M., and Clendenin, Jr., C.W., 1975, Guidebook to the geology and ore deposits of selected mines in the Viburnum Trend, Missouri: Rolla, Missouri Division of Geology and Land Survey Report of Investigations 58, $56 \mathrm{p}$.

Winslow, Arthur, 1894, Lead and zinc deposits: Rolla, Missouri Division of Geology and Land Survey, v. 5 and $6,763 \mathrm{p}$. 


\section{REFERENCES CITED--Continued}

Wixson, B.G., Gale, N.L., Elliott, L.E., and Davies, B.E., 1982, Influences of tailings from the Old Lead Belt of Missouri on sediments of the Big River, in Hemphill, D.D., ed., Trace Elements in Environmental Health, 16th, Columbia, Mo., 1982 Proceedings: Columbia, University of Missouri, p. 3-11.

Zachritz, W.H., 1978, The effects of the "Old Lead Belt" mining district of southeastern Missouri on the water quality and sediments of the Big River basin: University of Missouri-Rolla, unpublished M.S. thesis, $103 \mathrm{p}$. 


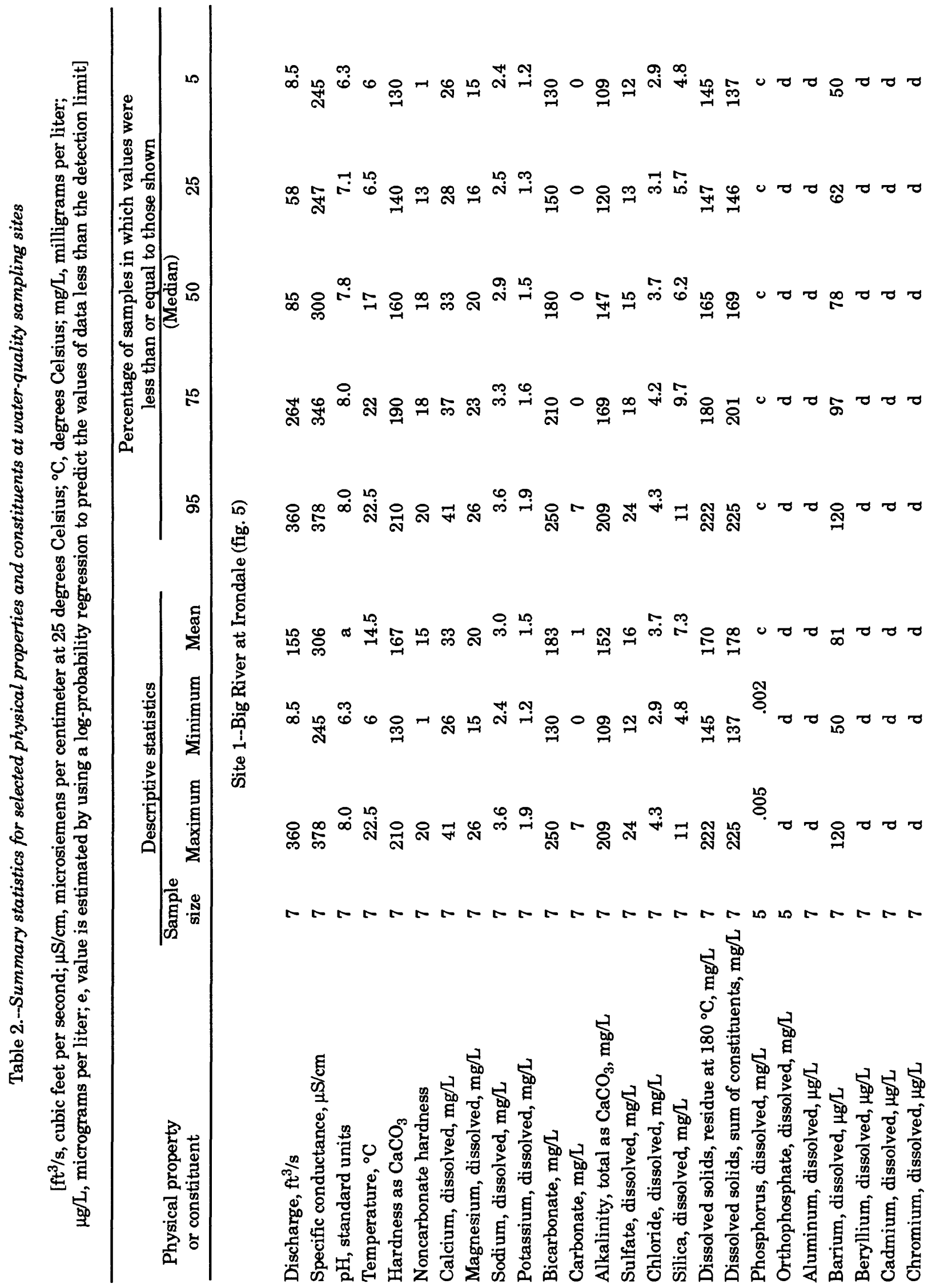




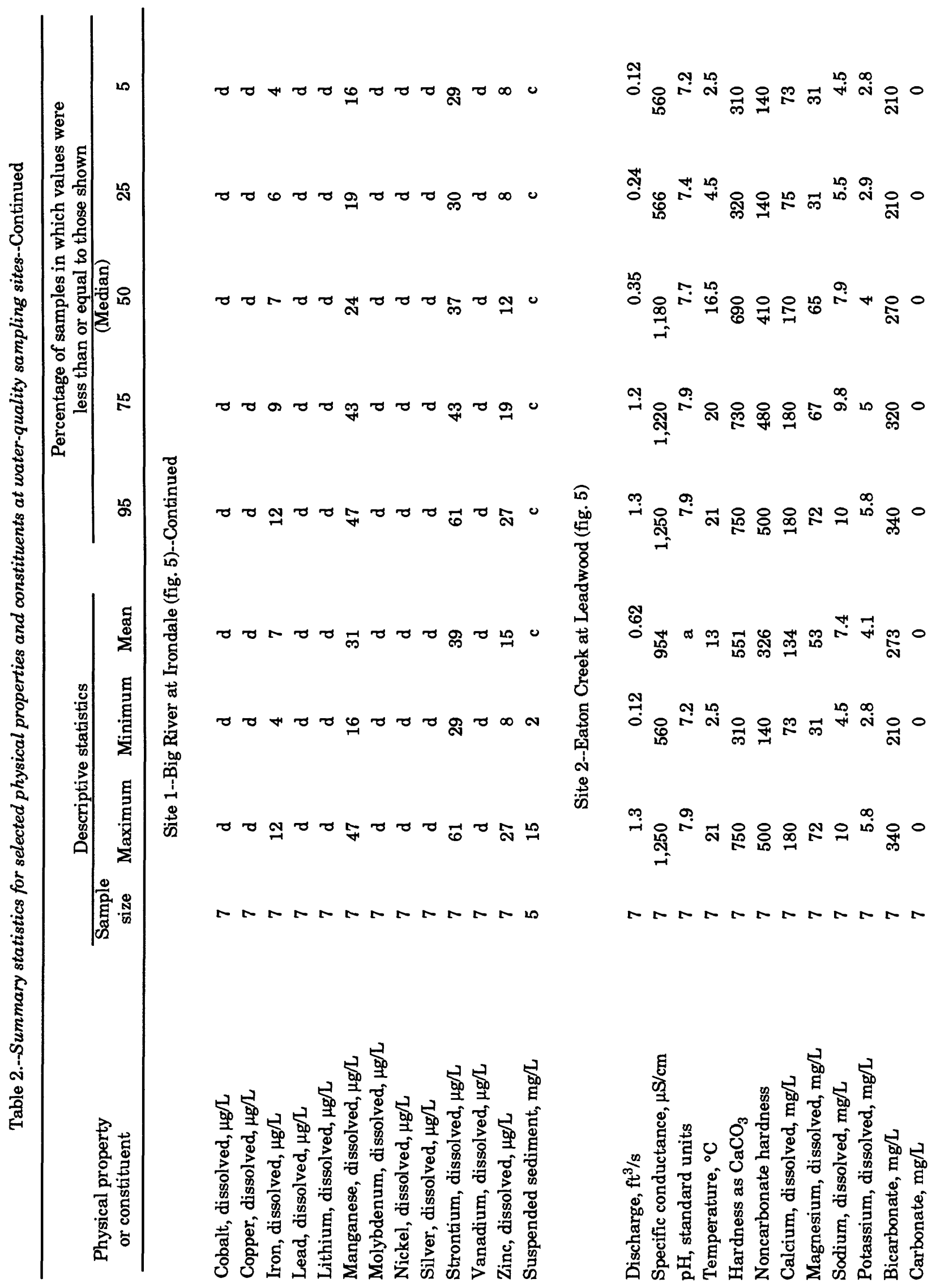




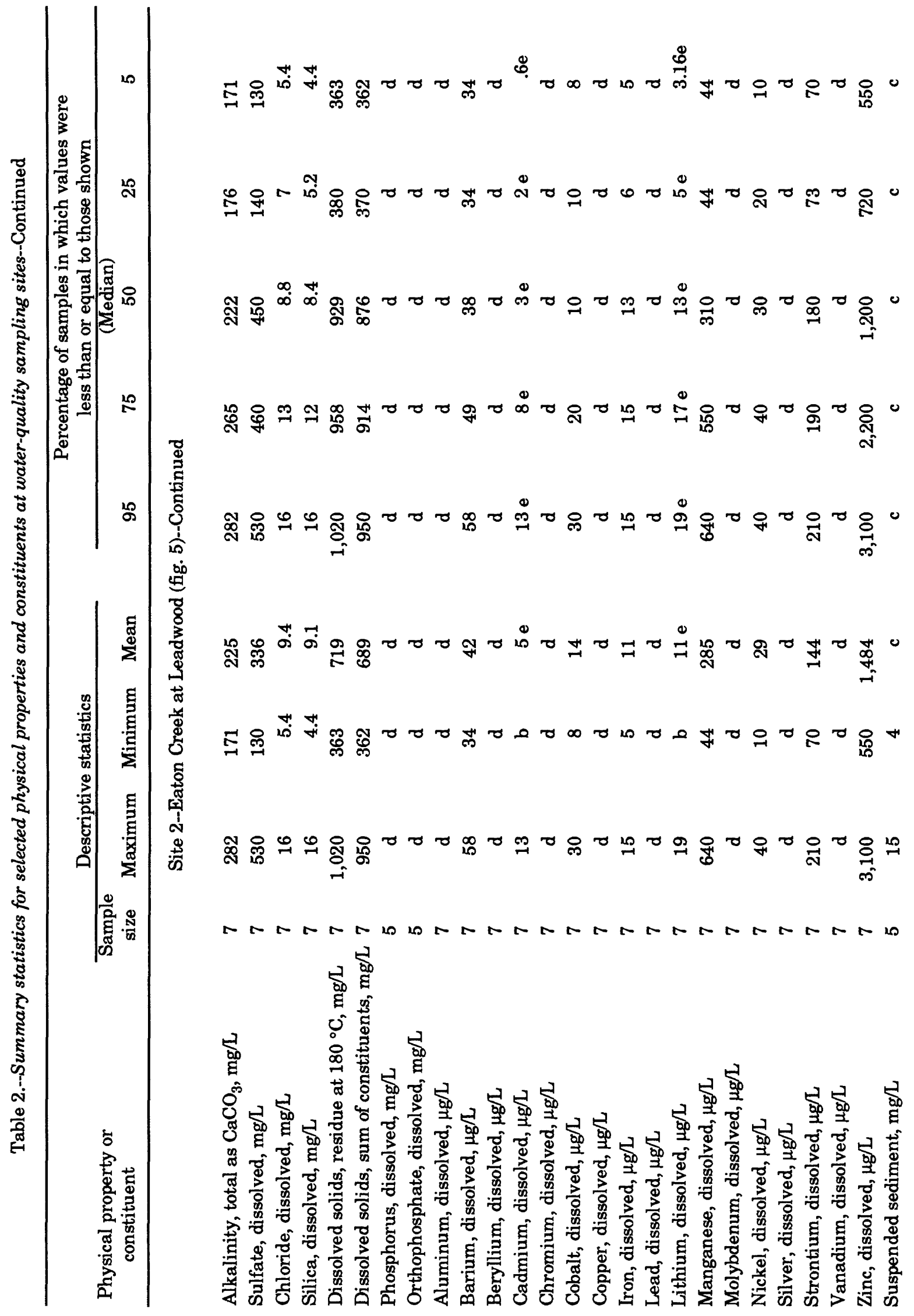




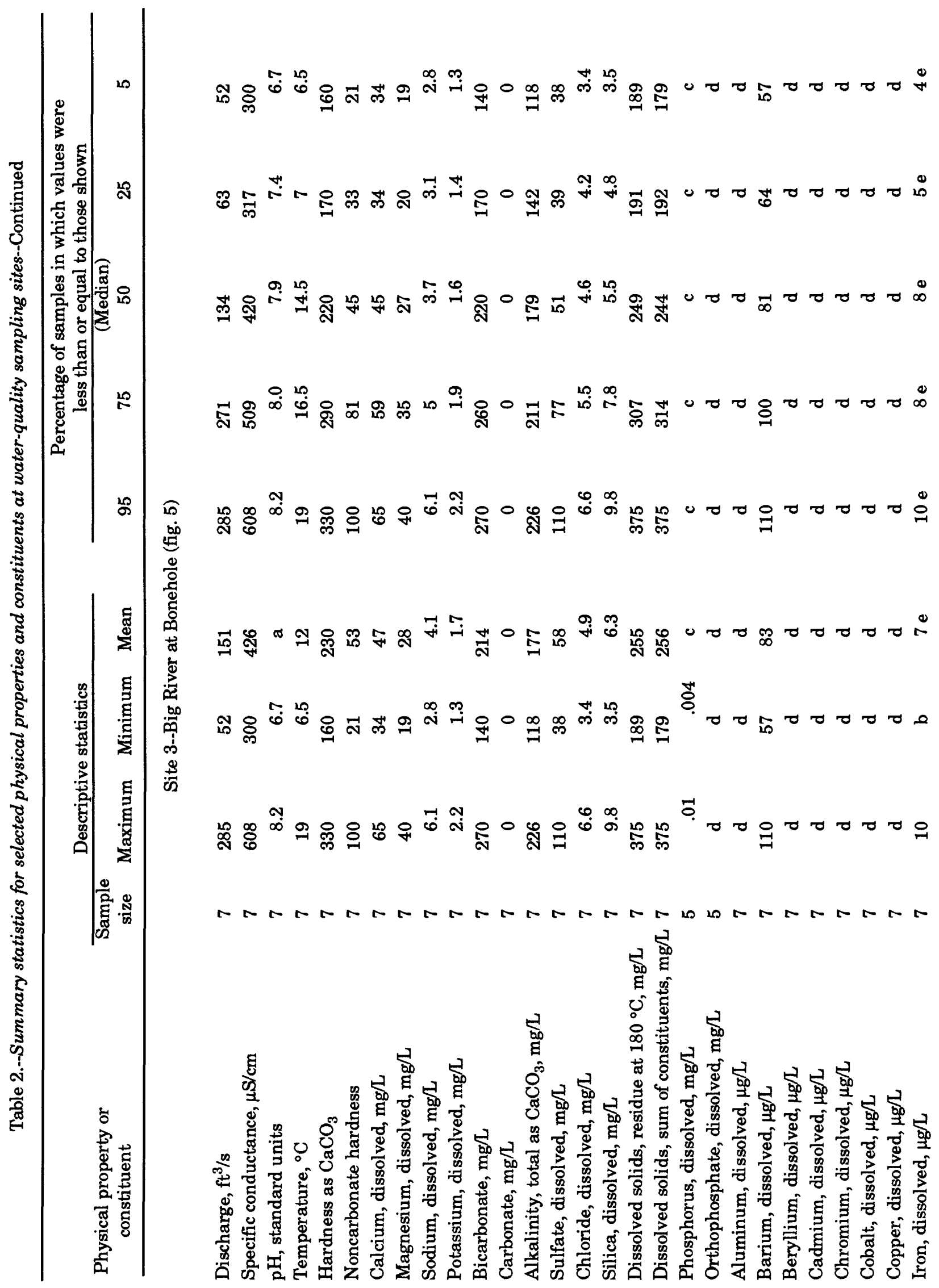




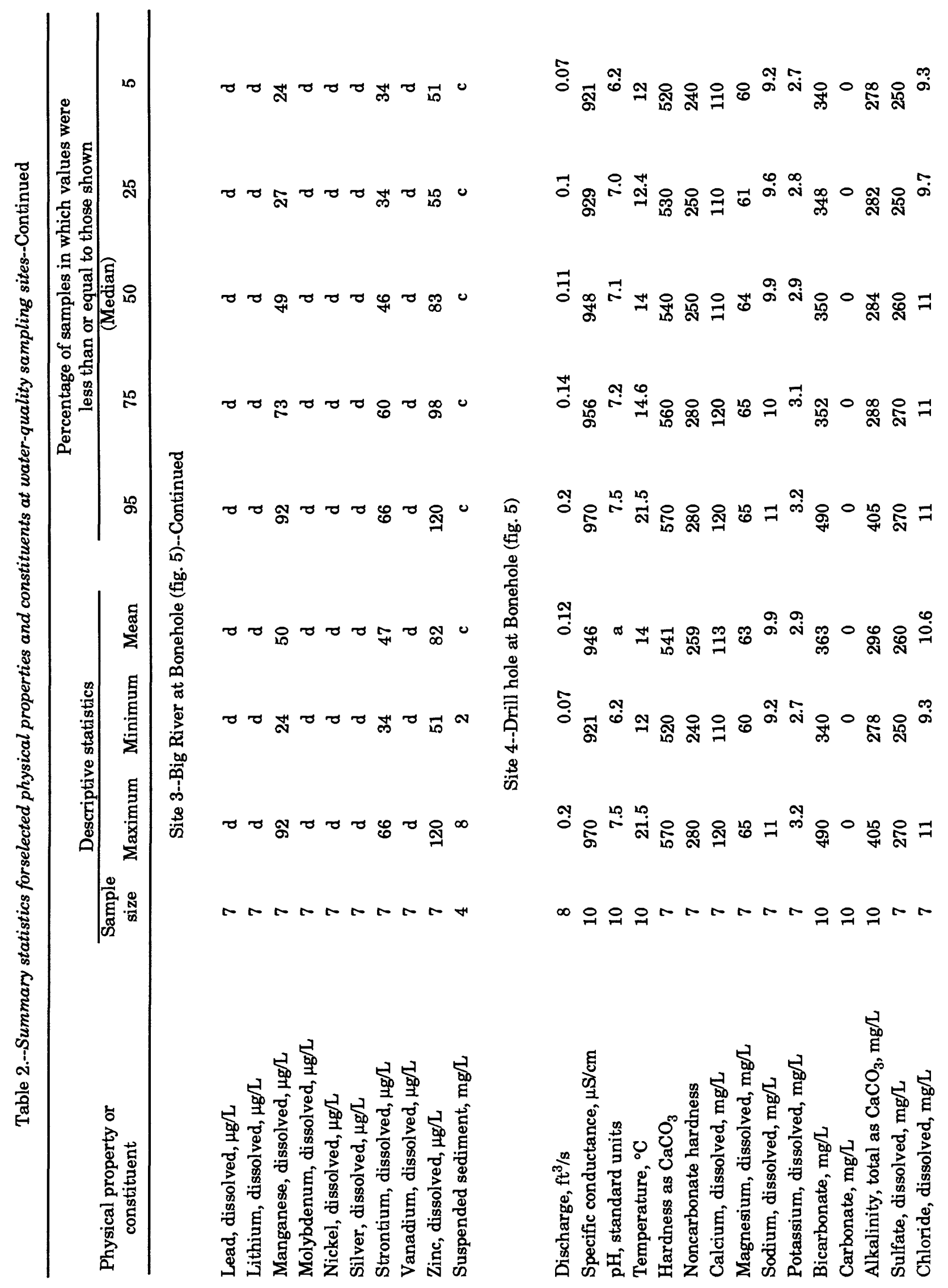




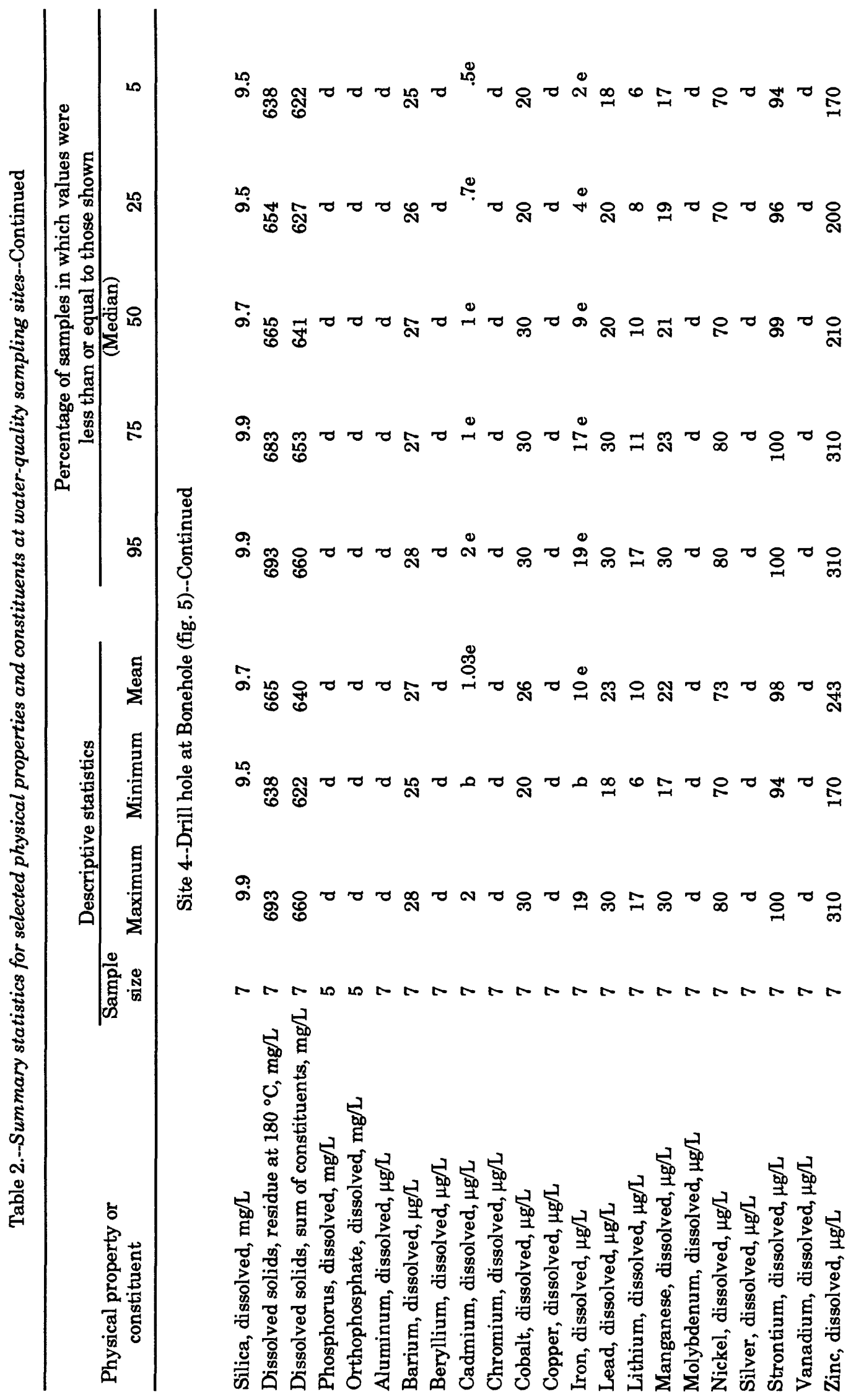




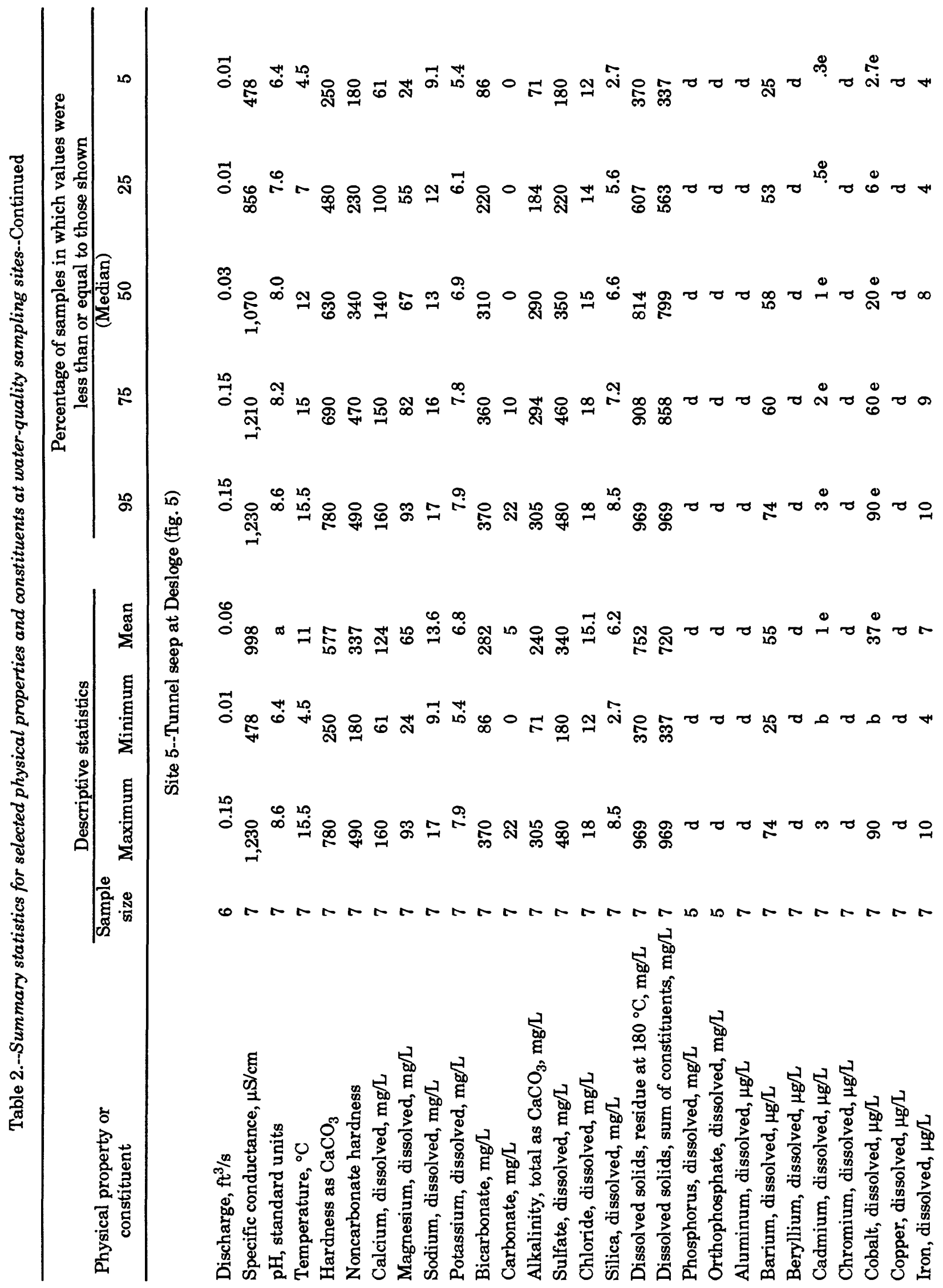




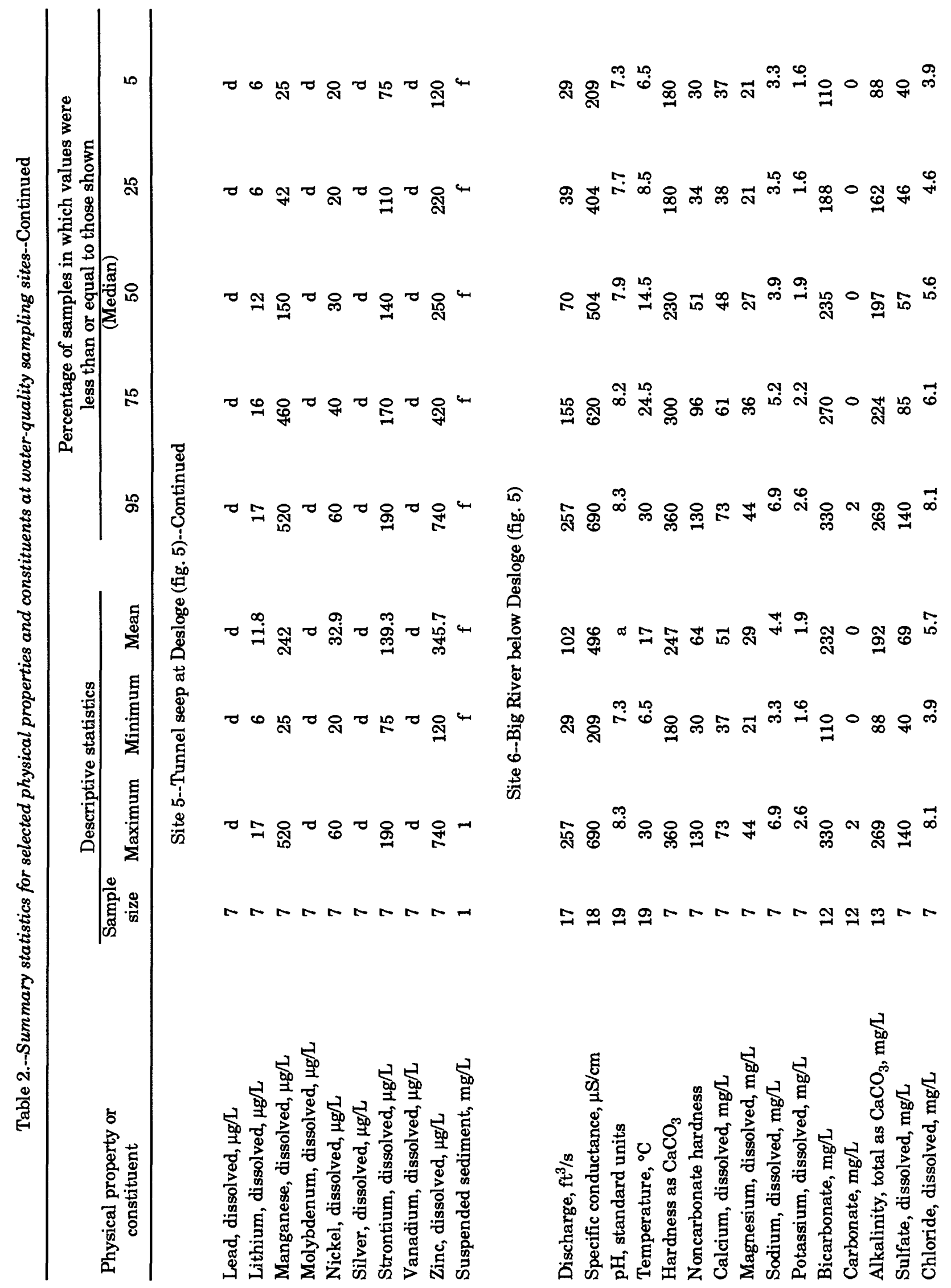




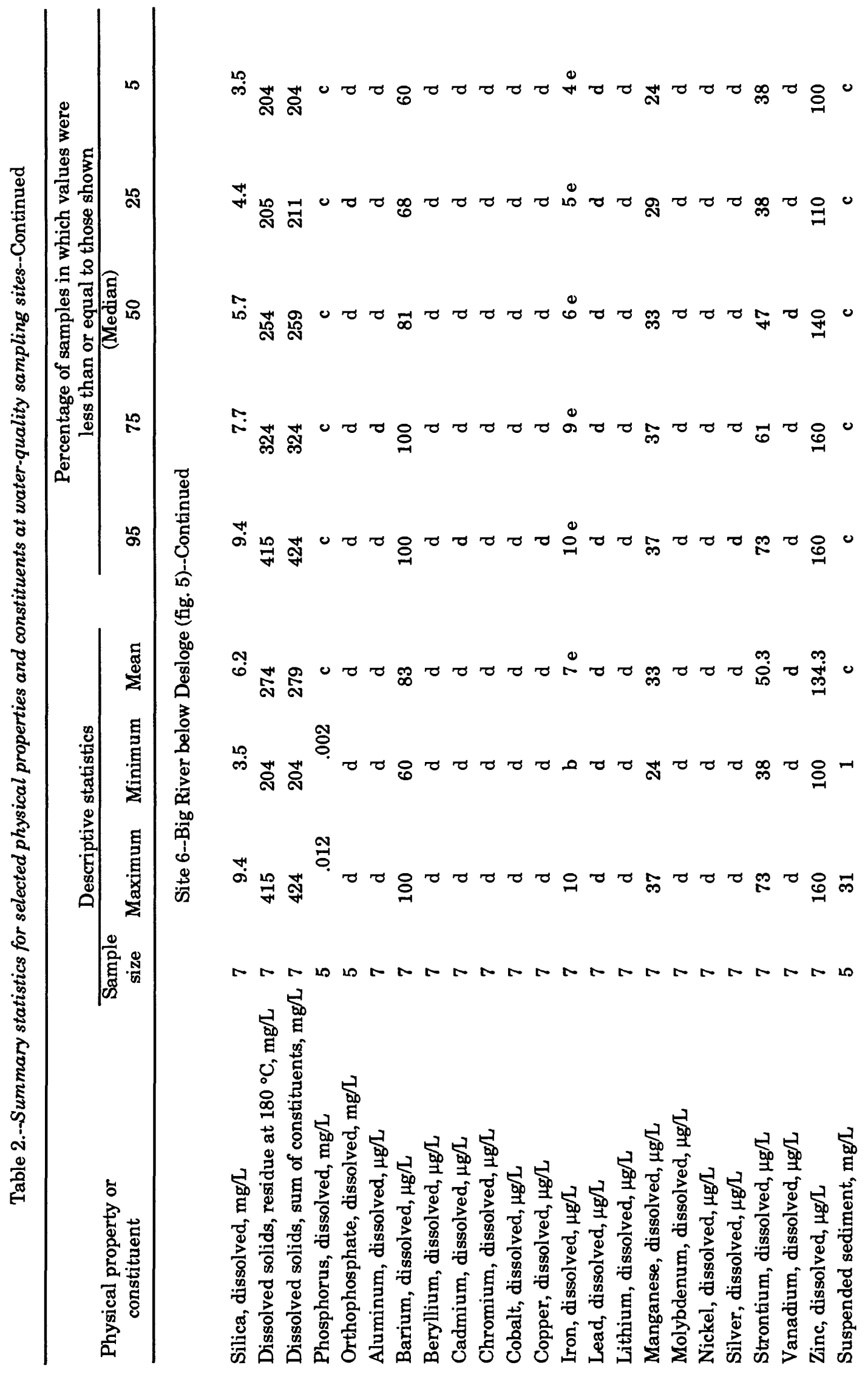




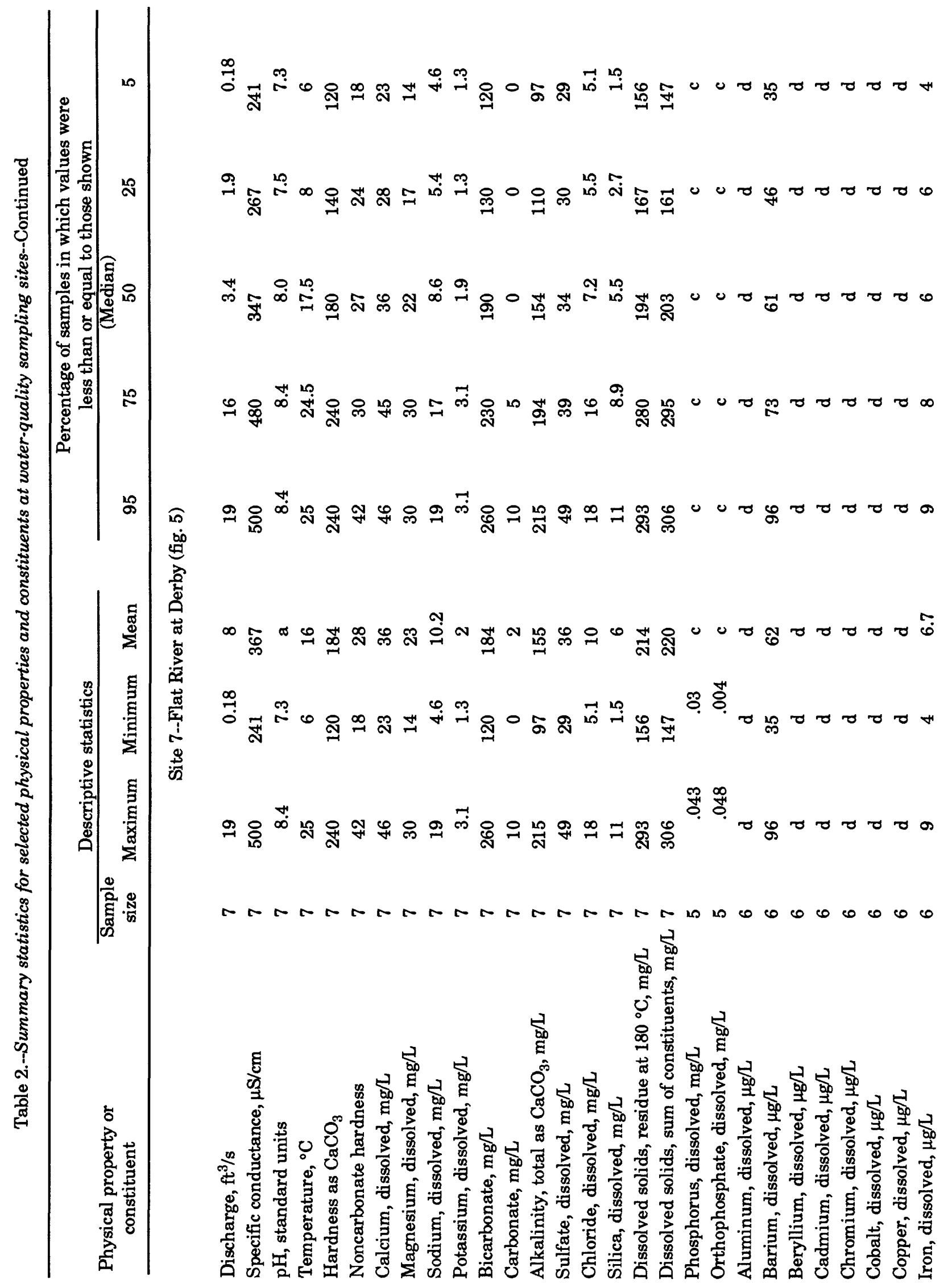




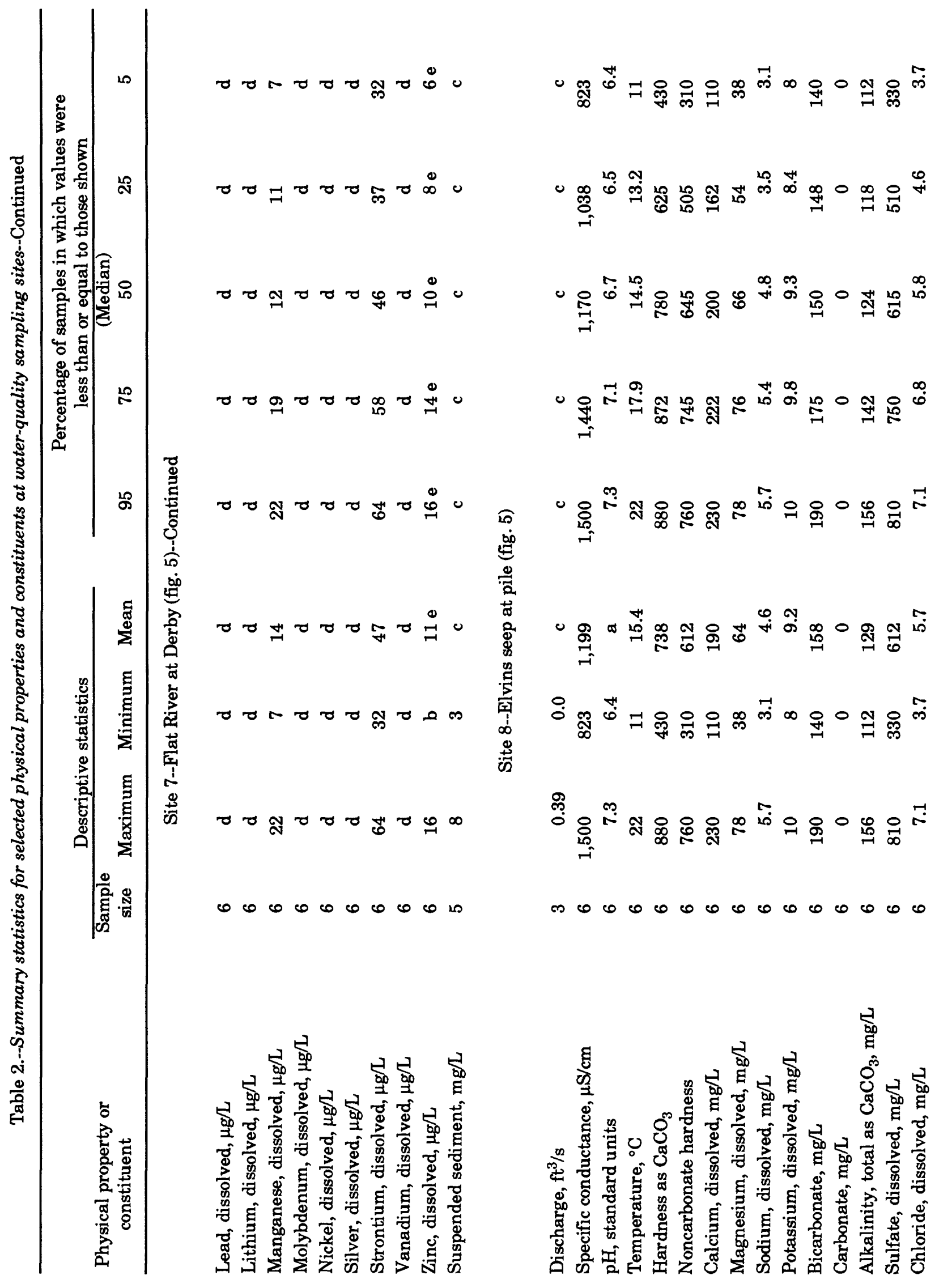




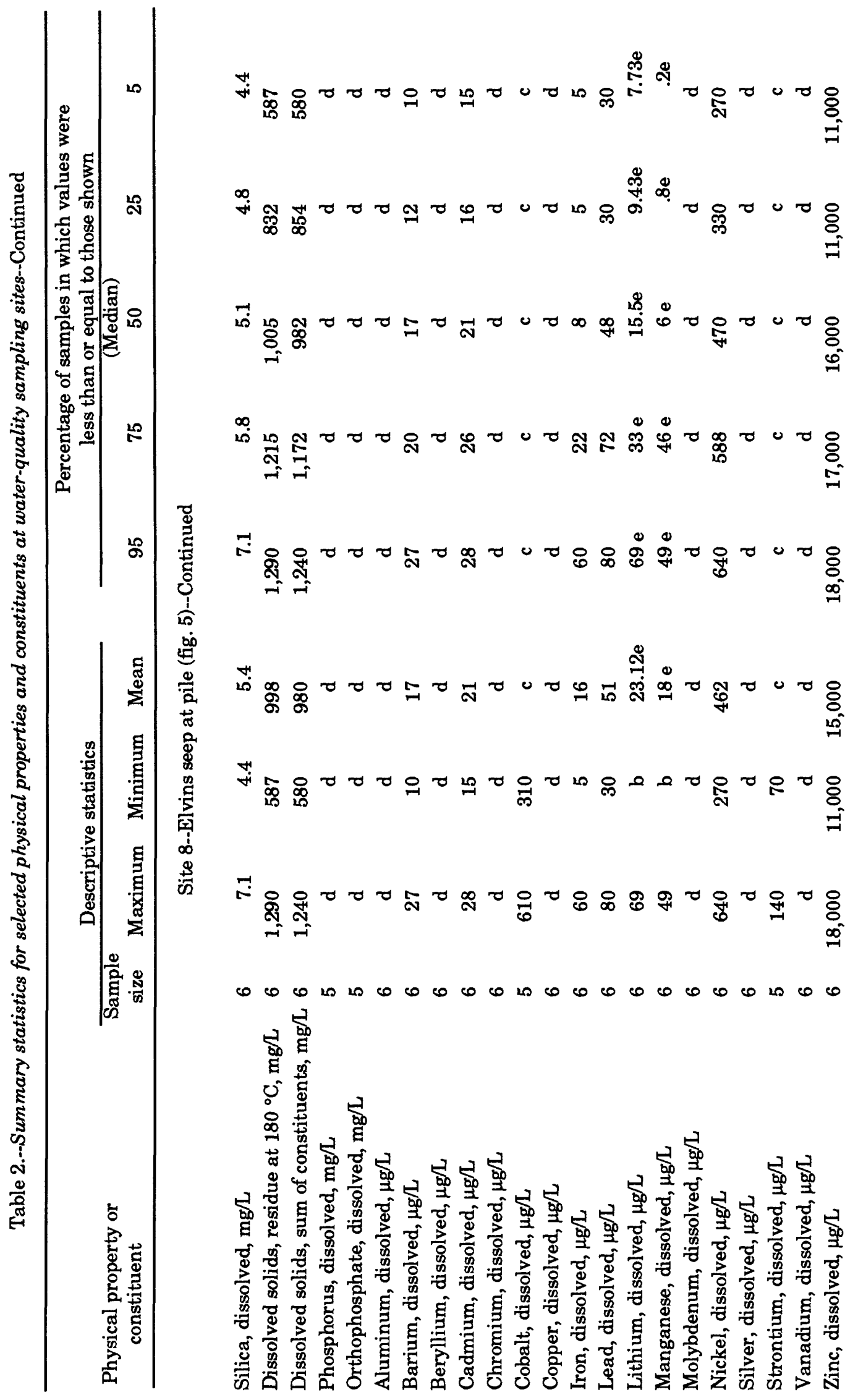




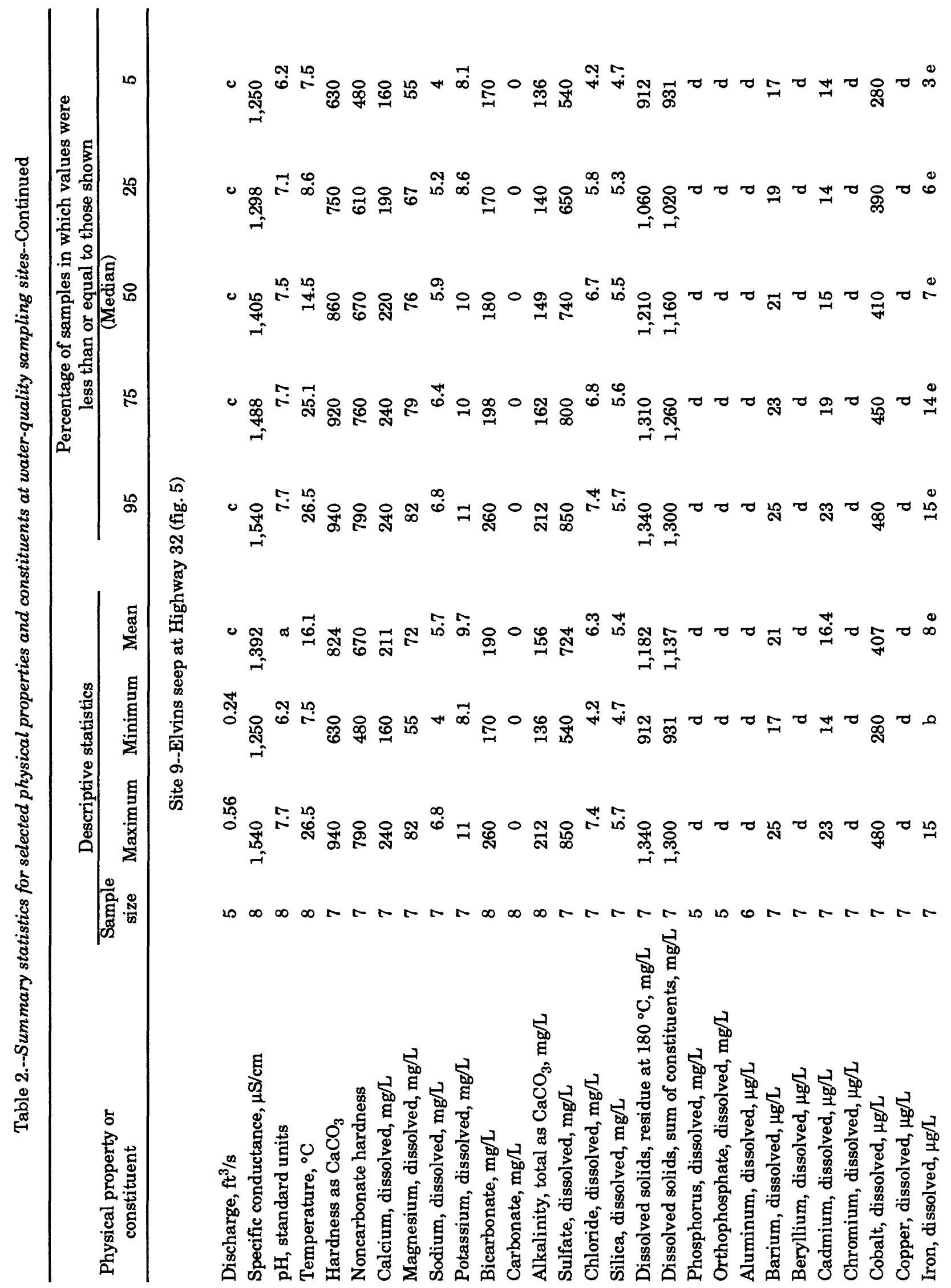




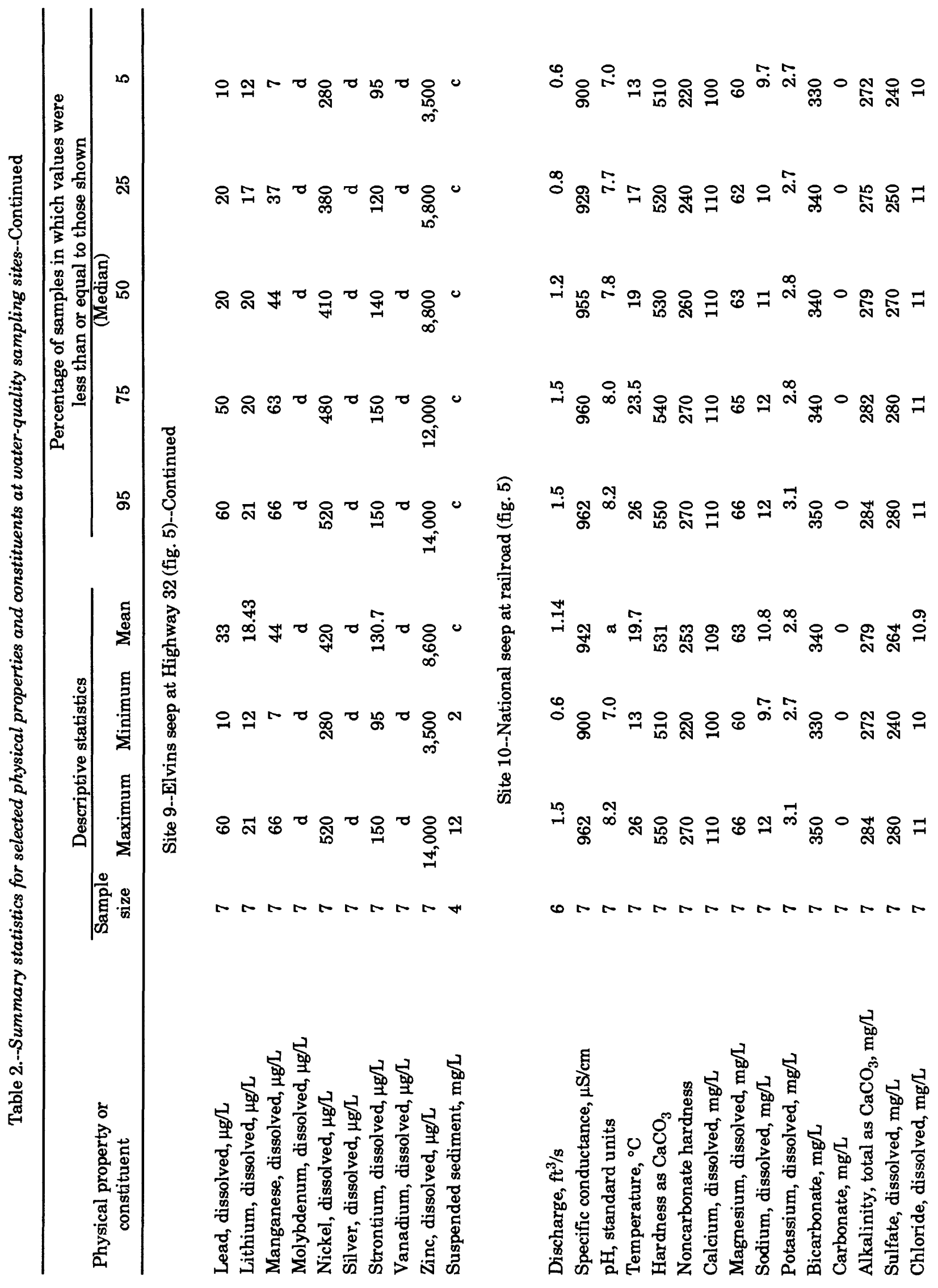




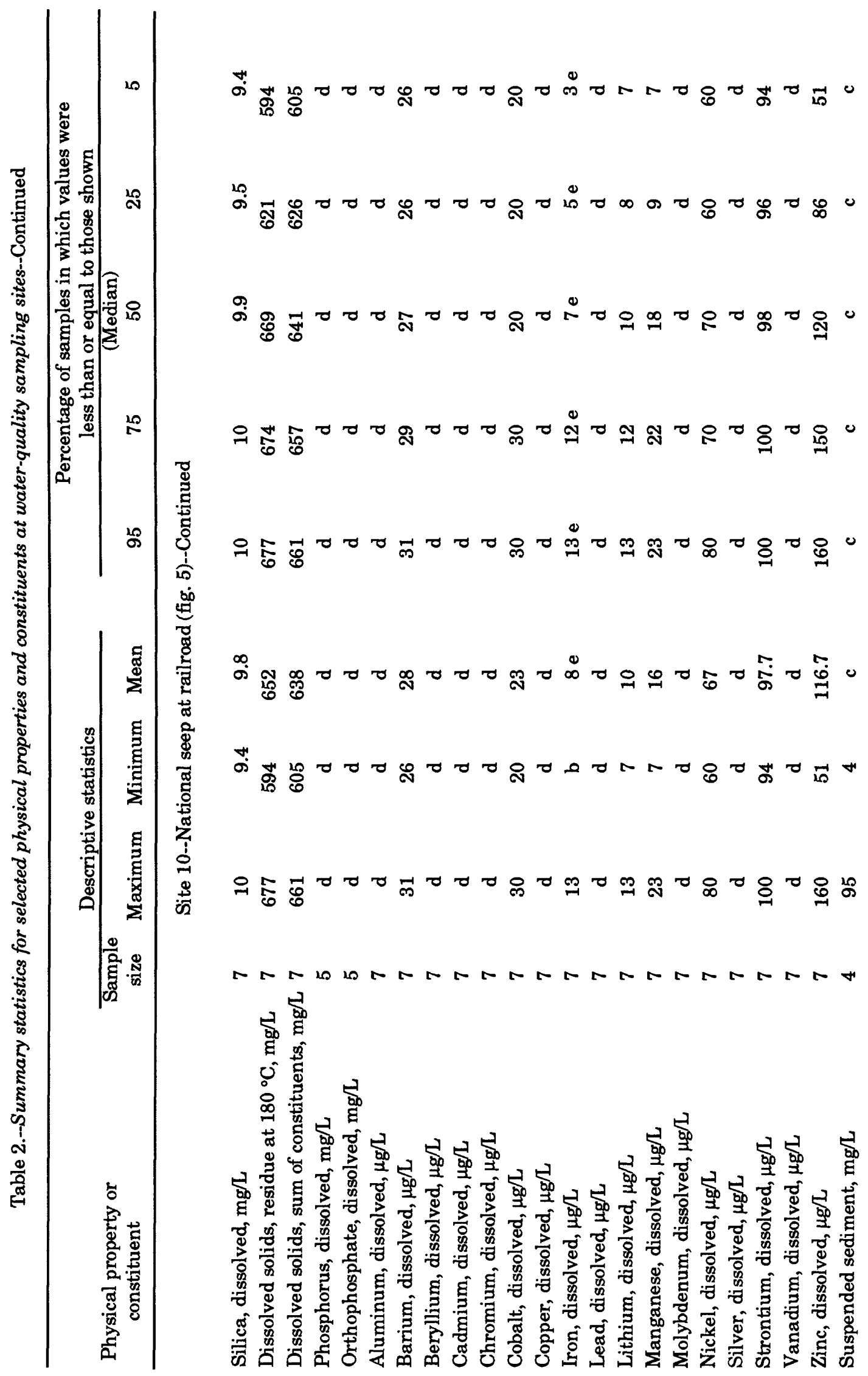




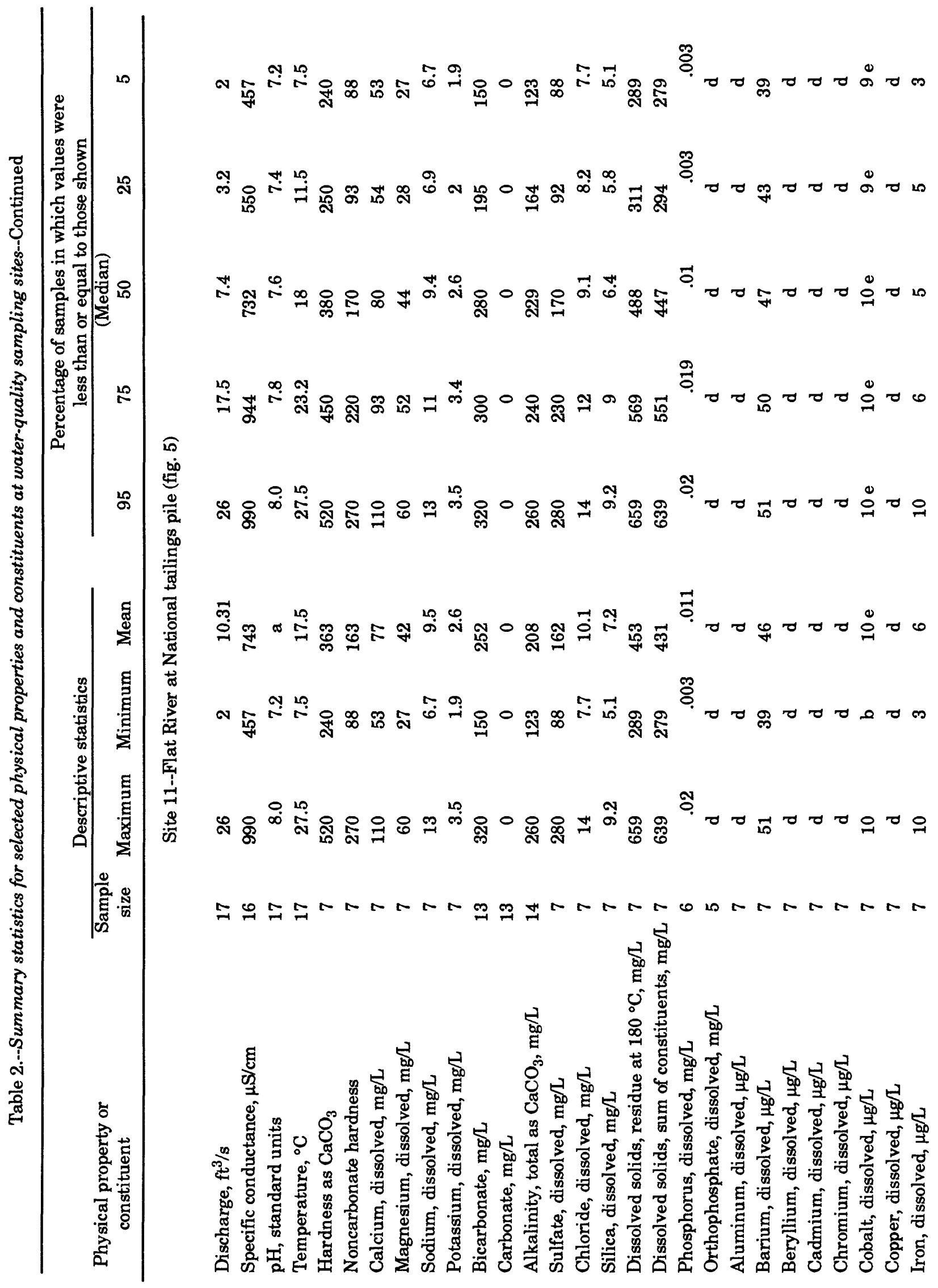




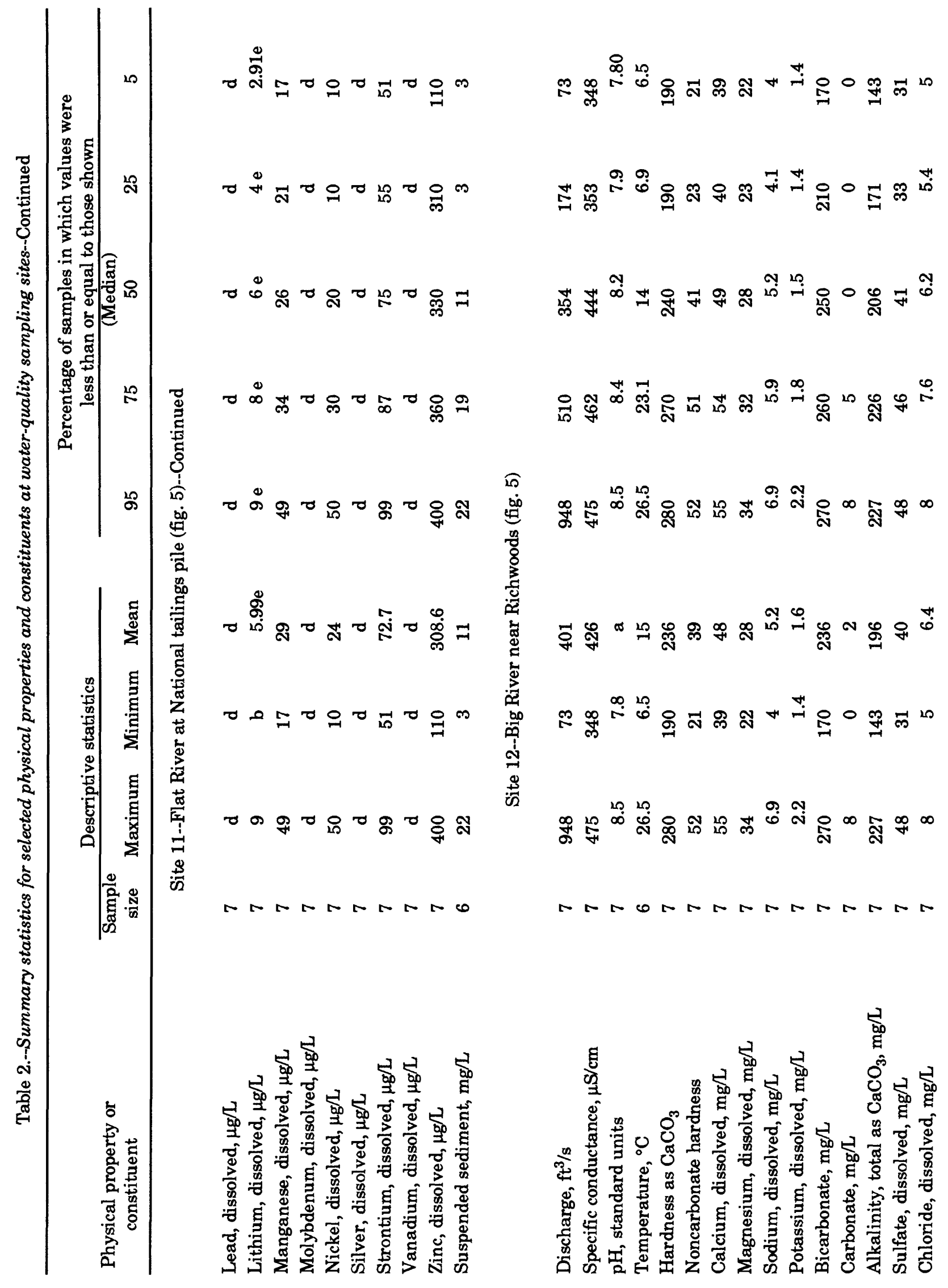




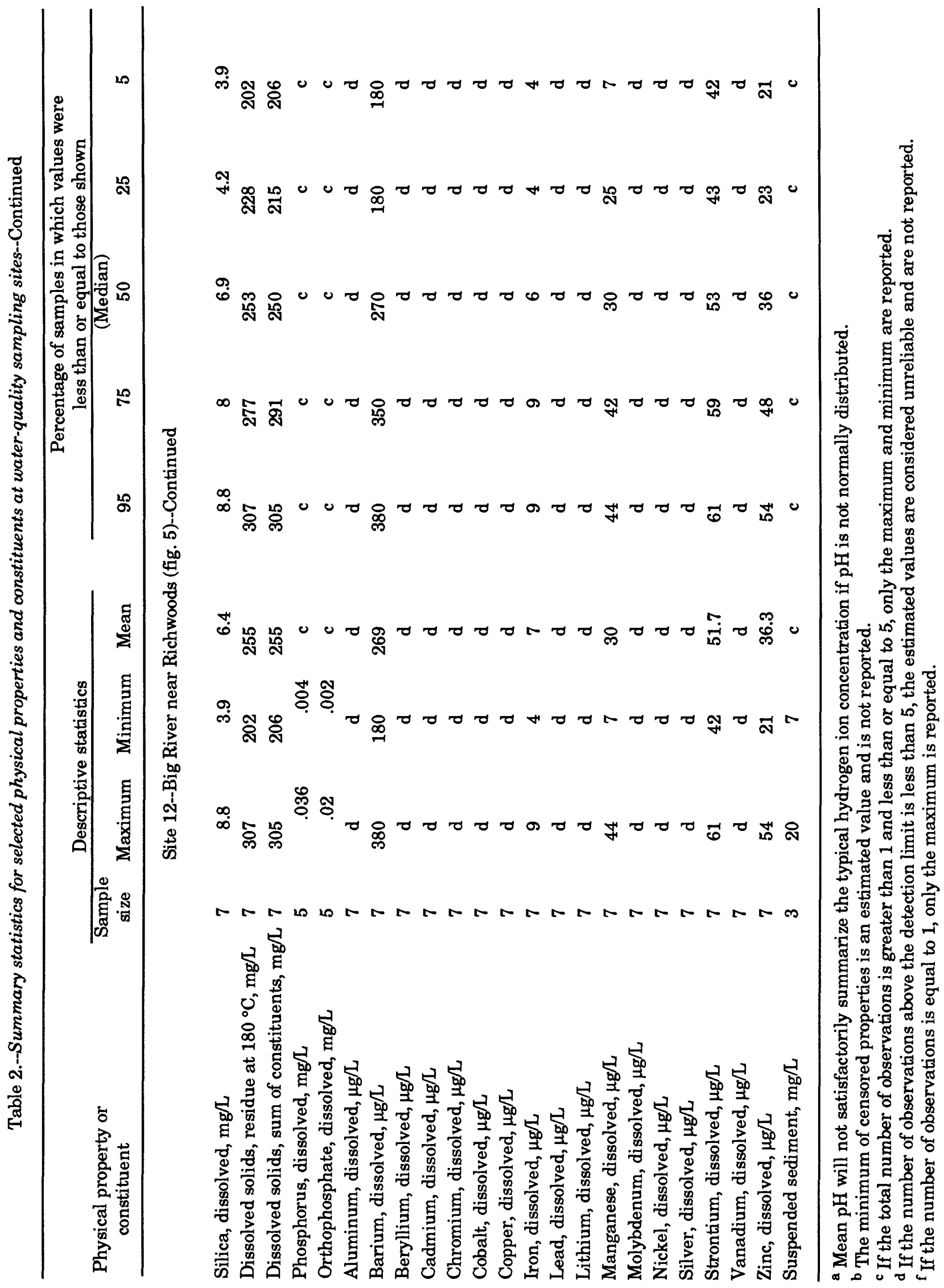

